UNIVERSIDADE DE SÃO PAULO

FACULDADE DE FILOSOFIA, LETRAS E CIÊNCIAS HUMANAS

DEPARTAMENTO DE GEOGRAFIA

PROGRAMA DE PÓS-GRADUAÇÃO EM GEOGRAFIA FÍSICA

Rodrigo Augusto Stabile

LIMITES CRÍTICOS TOPOGRÁFICOS DE FEIÇÕES EROSIVAS LINEARES EM PIRATININGA (SP)

VERSÃO CORRIGIDA

São Paulo

2013 
Rodrigo Augusto Stabile

\section{LIMITES CRÍTICOS TOPOGRÁFICOS DE FEIÇÕES EROSIVAS LINEARES EM PIRATININGA (SP)}

Dissertação apresentada ao Programa de PósGraduação em Geografia Física da Faculdade de Filosofia, Letras e Ciências Humanas da Universidade de São Paulo para a obtenção do título de Mestre.

Orientadora: Prof ${ }^{\mathrm{a}}$. Dr ${ }^{\mathrm{a}}$. Bianca Carvalho Vieira Área de Concentração: Geografia Física Linha de Pesquisa: Estudos interdisciplinares em pedologia e geomorfologia

VERSÃO CORRIGIDA

São Paulo 


\section{FICHA CATALOGRÁFICA}

Catalogação na Publicação

Serviço de Biblioteca e Documentação

Faculdade de Filosofia, Letras e Ciências Humanas da Universidade de São Paulo

Stabile, Rodrigo Augusto

Limites críticos topográficos de feições erosivas lineares em Piratininga (SP)/

Rodrigo Augusto Stabile; orientadora: Bianca Carvalho Vieira - São Paulo, 2013.

103f.; il.

Dissertação (Mestrado) - Faculdade de Filosofia, Letras e Ciências Humanas da Universidade de São Paulo. Departamento de Geografia. Área de concentração: Geografia Física.

1. Geomorfologia. 2. Erosão linear. 3. Limite crítico topográfico. 4. Área de contribuição.

I. Vieira, Bianca Carvalho. II. Universidade de São Paulo - Programa de Pós-graduação em Geografia Física. III. Título de Mestre. 


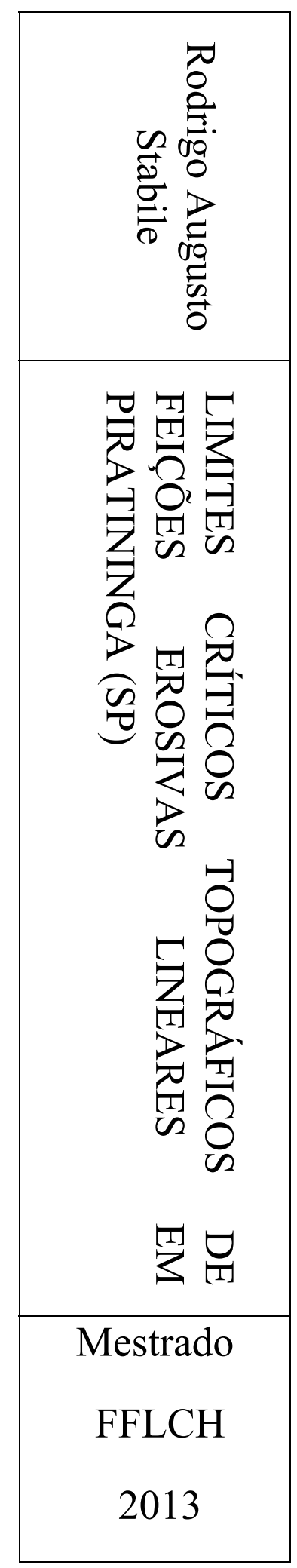

Rodrigo Augusto Stabile 
Rodrigo Augusto Stabile

\section{Limites críticos topográficos de feições erosivas lineares em Piratininga (SP)}

Dissertação apresentada ao Programa de PósGraduação em Geografia Física da Faculdade de Filosofia, Letras e Ciências Humanas da Universidade de São Paulo para a obtenção do título de Mestre.

Banca Examinadora

Prof $^{a}$. Dra. Bianca Carvalho Vieira (Orientadora)

Departamento de Geografia - Universidade de São Paulo

Prof. Dr. Nelson Ferreira Fernandes

Departamento de Geografia - Universidade Federal do Rio de Janeiro

Prof. Dr. Leonardo José Cordeiro Santos

Departamento de Geografia - Universidade Federal do Paraná

São Paulo, 2013 


\section{AGRADECIMENTO}

Agradeço à Fundação de Amparo à Pesquisa do Estado de São Paulo (FAPESP)

pelo financiamento desta pesquisa por meio da bolsa de Mestrado, concedida entre 01/08/2009 e $31 / 10 / 2009$. 


\section{RESUMO}

Considerando a importância de se definir as condições críticas para a deflagração, desenvolvimento e estabilização das voçorocas e outras feições erosivas lineares, e tendo em conta as poucas abordagens nesse sentido realizadas no Brasil, o objetivo geral desta pesquisa é avaliar os limites críticos topográficos para o desenvolvimento das formas resultantes da erosão linear em Piratininga (SP). Os procedimentos metodológicos envolveram a identificação e caracterização das feições erosivas por meio de fotografias aéreas e in situ; a mensuração da declividade $(S)$ em campo e com diversas resoluções de Modelo Digital de Terreno (MDT) e da Área de Contribuição $(A)$ também a partir do MDT; e, a definição dos limites críticos topográficos na forma da seguinte Função Potência: $S=a \times A^{b}$. A linha do limite crítico foi ajustada no limite inferior dos dados, paralelamente à inclinação linha ortogonal de regressão de $S$ e $A$. As feições erosivas foram categorizadas em 4 classes e 13 subclasses de acordo com seus aspectos morfométricos e indicadores dos processos atuantes. A mensuração de $S$ e $A$ por diferentes métodos resultou em algumas variações significativas nos dados gerados, sobretudo na comparação entre os valores obtidos em campo e pelo MDT. Foi obtido o seguinte limite crítico topográfico: $S=0,064 \times A^{-0,084}$, que tem coeficientes semelhantes a outras pesquisas que analisaram feições erosivas resultantes do escoamento subsuperficial. A distinção entre as feições erosivas onde ainda há indícios de recuo das cabeceiras e feições erosivas que já atingiram o equilíbrio, assim como a análise dos pontos de início dos processos erosivos em relação ao limite crítico, forneceu bases empíricas para a discussão da evolução das feições erosivas lineares em relação ao limite crítico topográfico e também para ao entendimento dos estados estável e instável dos voçorocamentos, permitindo a construção de um modelo teórico de previsão da estabilidade e instabilidade das feições erosivas baseado na relação entre a declividade e a área de contribuição em diferentes perfis de encosta.

Palavras-chave: Geomorfologia, Erosão linear, Limite crítico topográfico, Área de Contribuição, Declividade. 


\begin{abstract}
Considering the importance of defining the critical conditions for the generation, development and stabilization of gullies and other erosional features, and taking into account the few approaches accordingly held in Brazil, the aim of this research is to evaluate the topographical critical limits for developing of gully erosion in Piratininga (SP). The methodological procedures involved: the identification and characterization of the gullies using aerial photographs and in situ; measurement of the slope $(S)$ in the field and with various resolutions of Digital Terrain Model (DTM) and drainage area (A) also from DTM, and the definition of topographical thresholds in the form of following Power Function: $S=a \times A^{b}$. The topographical threshold line has been set at the lower limit of data, parallel to the slope of orthogonal regression line of $S$ and $A$. The erosional features were categorized into 4 classes and 13 subclasses according to their morphometric aspects and indicators of active processes. The measurement of $S$ and $A$ by different methods resulted in some significant changes in the data generated, particularly when comparing the values obtained in the field and the DTM. We obtained the following topographic threshold: $S=0,064 \times A^{-0,084}$ which has coefficients similar to other studies that analyzed erosional features resulting from subsurface flow. The distinction between active and stabilized gullies, as well as analysis of the starting points of erosion in relation to threshold line, provide an empirical basis for the discussion of the evolution of gullies in relation to the topographic threshold line and also for the understanding of stable and active states of gullies, allowing the construction of a theoretical model for predicting the stability and instability of the gullies based on the relationship between slope and drainage area in different slope profiles.
\end{abstract}

Key-words: Geomorphology, Gully erosion, Topographical threshold, Drainage area, Slope gradient. 


\section{LISTA DE FIGURAS}

FIGURA 1: DESENVOLVIMENTO DE REDES DE SULCOS EM DIFERENTES TIPOS DE SOLO APÓS 2 HORAS DE SIMULAÇÃO DE CHUVA A $60 \mathrm{MM} \mathrm{H}^{-1}$.

FIGURA 2: ESBOÇO DA ATUAÇÃO DOS PROCESSOS EROSIVOS EM UMA VOÇOROCA DESCONTÍNUA E DESCONECTADA DA REDE DE DRENAGEM NA COLÔNIA QUERO-QUERO, PALMEIRA (PR).

FIGURA 3: OCORRÊNCIA DE FLUTING NA CABECEIRA DE UMA BANK GULLIE EM GUADALENTIN (ESPANHA). 10

FIGURA 4: VOÇOROCA PRÓXIMA À ÁREA URBANA DE BAURU (SP). 13

FIGURA 5: PERMANENT (CLASSICAL) GULLY EM THYSSE KAMOR (SENEGAL); E, BANK GULLY EM LEEFDAAL (BÉLGICA) 15

FIGURA 6: FORMA EM PLANTA DAS FEIÇÕES EROSIVAS DA REGIÃO DE OURO PRETO (MG)...... 18 FIGURA 7: MORFOLOGIA DAS CABECEIRAS DAS GULLIES DE SIERRA DE GATA (ESPANHA)......... 18 FIGURA 8: PERFIL DE ENCOSTA ILUSTRANDO OS PROCESSOS DE EROSÃO DO SOLO CONFORME A DESCRIÇÃO DE HORTON (1945).

FIGURA 9: RELAÇÃO ENTRE ÁREA DE CONTRIBUIÇÃO E DECLIVIDADE LOCA EM CABECEIRAS DE CANAIS DO TENESSEE VALLEY, CALIFÓRNIA (ESTADOS UNIDOS).

FIGURA 10: RELAÇÃO ENTRE ÁREA DE CONTRIBUIÇÃO E DECLIVIDADE LOCAL EM DEEP GULLIES E SHALLOW EPHEMERAL GULLIES NO LOESS BELT BELGA. .

FIGURA 11: DEMONSTRAÇÃO DA VARIAÇÃO NAS CARACTERÍSTICAS AO LONGO DAS FEIÇÕES EROSIVAS EM UMA DAS FEIÇÕES EM ESTUDO..

FIGURA 12: EXEMPLO DE UMA CABECEIRA DE DRENAGEM ESTUDADA .35

FIGURA 13: ESQUEMA ILUSTRATIVO DE UM PANTÔMETRO. .37

FIGURA 14: EXEMPLO DA UTILIZAÇÃO DO PANTÔMETRO NA MENSURAÇÃO DA DECLIVIDADE A MONTANTE DA CABECEIRA DE UMA FEIÇÃO EROSIVA E, DETALHE DA LEITURA DO ÂNGULO NO TRANSFERIDOR E DO NÍVEL DE BOLHA.

FIGURA 15: DETALHE NA ESCALA 1:10.000 DOS MAPAS DE DECLIVIDADE E ÁREA DE CONTRIBUIÇÃO GERADOS A PARTIR DO MDT COM RESOLUÇÃO DE 10X10 METROS EM UMA DAS CABECEIRAS DE DRENAGEM ESTUDADAS.

FIGURA 16:EXEMPLO HIPOTÉTICO DE RELAÇÃO ENTRE S E A. .40

FIGURA 17 MÉDIA MENSAL DE TEMPERATURA E PLUVIOSIDADE (PIRATININGA-SP). 47

FIGURA 18: ESQUEMA DE PAREDE DA VOÇOROCA SENHOR MENINO EM CASA BRANCA (SP) ... 50 FIGURA 19: POTENCIAL DE EROSÃO (PE) PARA AS CLASSES DE DECLIVIDADE E CURVATURA EM PLANTA NA BACIA DA ÁGUA DA FACA. STABILE.

FIGURA 20: DISTRIBUIÇÃO DAS 73 CABECEIRAS DE FEIÇÕES EROSIVAS ATUAIS ESTUDADAS DE ACORDO COM A CLASSIFICAÇÃO PROPOSTA.....

FIGURA 21: VOÇOROCA COM DIVERSOS SULCOS PARTINDO DE SEU CORPO NO ANO DE 1972 .. 55 FIGURA 22 CANAL GRAMADO NO ANO DE 1972, QUANDO AINDA ERA UMA FEIÇÃO ATIVA (VOÇOROCA DE CABECEIRA COM FUNDO PLANO).

FIGURA 23: VISTA DE UMA DAS CABECEIRAS CLASSIFICADAS COMO IVA. NOTA-SE UM PERFIL TRANSVERSAL SUAVE E A AUSÊNCIAS DE EVIDÊNCIAS DE PROCESSOS EROSIVOS ATUAIS.....56 
FIGURA 24: EXEMPLAR DE CABECEIRA CLASSIFICADA COMO IVC, NESTE CASO MAIS ESTABILIZADA, SENDO QUE A PORÇÃO ENTERRADA SITUAVA-SE A MONTANTE ..........................57

FIGURA 25: OUTRA CABECEIRA CLASSIFICADA COMO IVC, PORÉM COM INDÍCIOS DE ESCOAMENTO SUPERFICIAL QUE PROMOVERAM A REATIVAÇÃO DA FEIÇÃO. ..............................58

FIGURA 26: VISÃO DA MARGEM ESQUERDA DO CANAL CLASSIFICADO NA CATEGORIA III. A VEGETAÇÃO IMPEDE A CLARA VISUALIZAÇÃO DO CANAL

FIGURA 27: FEIÇÃO EROSIVA DO TIPO IC. OS LIMITES SUAVES E A COBERTURA POR VEGETAÇÃO GRAMÍNEA FAZEM COM QUE A FEIÇÃO NÃO SE DESTAQUE NA PAISAGEM. .......... 60 FIGURA 28: FEIÇÃO EROSIVA DA CLASSE IA E DETALHE DE PARTE DE SUA CABECEIRA ............61 FIGURA 29: CABECEIRA DE FEIÇÃO EROSIVA DA CLASSE IB E DETALHE DA MESMA CABECEIRA

FIGURA 30: LOCAL DE AFLORAMENTO DO LENÇOL FREÁTICO EM UMA DAS VOÇOROCAS DA CLASSE IA

FIGURA 31: CALHA DE UM DOS AFLUENTES DO RIO ALAMBARI A JUSANTE DE UMA VOÇOROCA DA CLASSE IA..

FIGURA 32: EXEMPLO DE RUPTURA CONNCAVA ONDE NORMALMENTE SE INICIAM AS VOÇOROCAS DE ENCOSTA

FIGURA 33: CABECEIRA DE VOÇOROCA DE ENCOSTA CIRCULAR ATIVA (CLASSE IIA). 66 FIGURA 34: CABECEIRA DE VOÇOROCA DE ENCOSTA CIRCULAR INATIVA (CLASSE IIB). .66 FIGURA 35 VISTA PARCIAL DE VOÇOROCA DE CABECEIRA LINEAR SIMPLES (CLASSE IID). ....... 67 FIGURA 36: VISÃO DE UM DOS PATAMARES DA VOÇOROCA DE ENCOSTA SUBTIPO LINEAR EM PATAMAR E DETALHE DA ALCOVA FORMADA POR PROCESSO DE PLUNGE POOL

FIGURA 37: VOÇOROCA DE ENCOSTA DO TIPO CANAL GRAMADO (CLASSE IIF).

FIGURA 38: GRÁFICOS DA CORRELAÇÃO ENTRE AS DIVERSAS MEDIDAS DE DECLIVIDADE. .... 72 FIGURA 39 COMPARAÇÃO ENTRE AS CLASSES DE DECLIVIDADE GERADAS PELO MDT COM RESOLUÇÃO DE 2X2M E PELO MDT COM RESOLUÇÃO DE 10X10M.

FIGURA 40: EXEMPLO DE IRREGULARIDADE NO RELEVO QUE GERA DISTORÇÕES NOS DADOS DE DECLIVIDADE MENSURADOS EM CAMPO COM O USO DO PANTÔMETRO.

FIGURA 41: GRÁFICOS DA CORRELAÇÃO ENTRE AS DIVERSAS MEDIDAS DE ÁREA DE CONTRIBUIÇÃO.

FIGURA 42: COMPARAÇÃO ENTRE AS CLASSES DE ÁREA DE CONTRIBUIÇÃO GERADAS PELO MDT COM RESOLUÇÃO DE 2X2M E PELO MDT COM RESOLUÇÃO DE 10X10M.

FIGURA 43: RELAÇÃO ENTRE ÁREA DE CONTRIBUIÇÃO E DECLIVIDADE PARA FEIÇÕES EROSIVAS COM CONDICIONAMENTO ANTRÓPICO (CLASSE IV) E SEM CONDICIONAMENTO ANTRÓPICO (CLASSES I, II E III)..

FIGURA 44: REPRESENTAÇÃO ESPACIAL DO LIMITE CRÍTICO TOPOGRÁFICO PARA AS FEIÇÕES EROSIVAS SEM CONDICIONAMENTO ANTRÓPICO.

FIGURA 45: RECORTE DA FOTOGRAFIA AÉREA DE 1972, COM A MARCAÇÃO DA CABECEIRA DA FEIÇÃO EROSIVA CLASSE IV.

FIGURA 46: EXEMPLOS DE CABECEIRAS DE FEIÇÕES EROSIVAS CLASSIFICADAS COMO: COM AUSÊNCIA DE PROCESSOS ATUAIS; COM POUCOS PROCESSOS ATUAIS; E, COM PRESENÇA DE PROCESSOS ATUAIS. 
FIGURA 47: RELAÇÃO ENTRE ÁREA DE CONTRIBUIÇÃO E DECLIVIDADE PARA AS FEIÇÕES EROSIVAS COM AUSÊNCIA DE PROCESSOS ATUAIS, COM POUCOS PROCESSOS ATUAIS E COM PRESENÇA DE PROCESSOS ATUAIS.

FIGURA 48: MODELOS TEÓRICOS DE VARIAÇÃO DA DECLIVIDADE DE ACORDO COM A DIMINUIÇÃO DA ÁREA DE CONTRIBUIÇÃO: 86

FIGURA 49: RELAÇÃO S X A PARA OS PONTOS DE INÍCIO E PARA CABECEIRAS DAS VOÇOROCAS MAPEADAS EM 1972

FIGURA 50: MODELO TEÓRICO DE VARIAÇÃO DA DECLIVIDADE DE ACORDO COM A DIMINUIÇÃO DA ÁREA DE CONTRIBUIÇÃO PARA ENCOSTAS CÔNCAVAS, OU SEJA, COM AUMENTO DA DECLIVIDADE E DIMINUIÇÃO DA ÁREA DE CONTRIBUIÇÃO.

FIGURA 51: EXEMPLO DE FEIÇÃO EROSIVA COM PONTO DE INÍCIO EM SETOR DA ENCOSTA CÔNCAVO EM PERFIL E COM CABECEIRA EM SETOR DA ENCOSTA COM PERFIL CONVEXO:......89

FIGURA 52: RELAÇÃO SA PARA FEIÇÕES EROSIVAS CLASSIFICADAS COMO VOÇOROCAS DE CABECEIRA (CLASSE I) E COMO CANAL CONSOLIDADO (CLASSE III).

FIGURA 53: RELAÇÃO ENTRE ÁREA DE CONTRIBUIÇÃO E DECLIVIDADE PARA FEIÇÕES EROSIVAS CLASSIFICADAS COMO VOÇOROCAS DE ENCOSTA (CLASSE II).

FIGURA 54: CABECEIRA DO TIPO IB, RELATIVAMENTE MAIS ABRUPTA, FORMANDO PAREDÕES ROCHOSOS DEVIDO À PRESENÇA DE ARENITO COM SEDIMENTAÇÃO CARBONÁTICA.

FIGURA 55: CABECEIRA DO TIPO IB, RELATIVAMENTE MENOS ABRUPTA E COM MATERIAL INCONSOLIDADO SOBREJACENTE AO ARENITO 


\section{LISTA DE MAPAS}

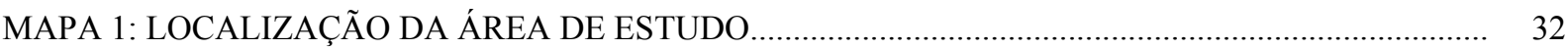

MAPA 2: LOCALIZAÇÃO DAS FEIÇÕES EROSIVAS ANALISADAS .....................................................

MAPA 3: MAPA GEOLÓGICO DA REGIÃO DE BAURU (SP)............................................................... 45

\section{LISTA DE TABELAS}

TABELA 1: RELAÇÕES POSSÍVEIS ENTRE ELEMENTOS E EVENTOS CAUSAIS EM DIFERENTES ESCALAS TEMPORAIS E ESPACIAIS

TABELA 2: SÍNTESE DE PESQUISAS QUE UTILIZARAM A ABORDAGEM ÁREA DE CONTRIBUIÇÃO - DECLIVIDADE

TABELA 3 SÍNTESE DAS CATEGORIAS DE FEIÇÕES EROSIVAS NA ÁREA DE ESTUDO .53 TABELA 4: COMPARAÇÃO DOS COEFICIENTES A E B ENCONTRADOS POR DIVERSAS PESQUISAS 


\section{SUMÁRIO}

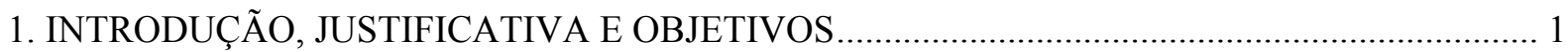

2. FUNDAMENTAÇÃO TEÓRICO-METODOLÓGICA E CONCEITUAL ....................................... 3

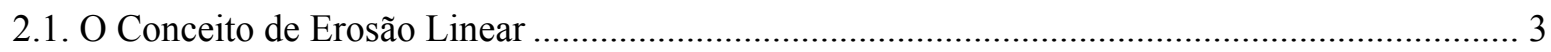

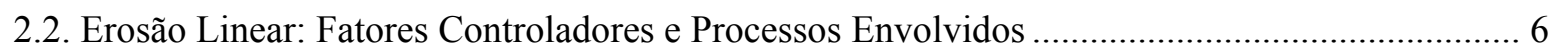

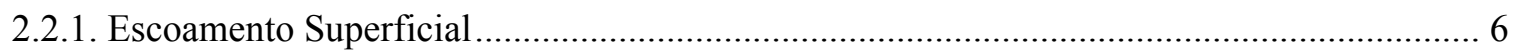

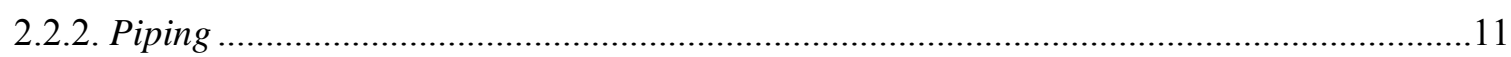

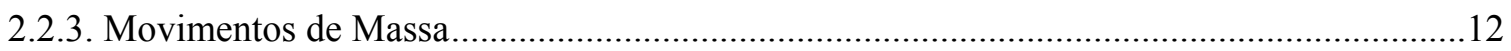

2.3. Classificação das Feições Erosivas Lineares..............................................................................14

2.4. O Conceito de Limite Crítico e o Problema da Escala ...................................................................19

2.5. Identificação dos Limites Críticos: A Abordagem Declividade - Área de Contribuição (SA)...21

2.6. Questões Metodológicas e a Abordagem Declividade - Área de Contribuição no Estudo da

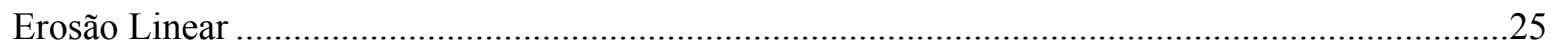

3. PROCEDIMENTOS METODOLÓGICOS E TÉCNICO-OPERACIONAIS ....................................31

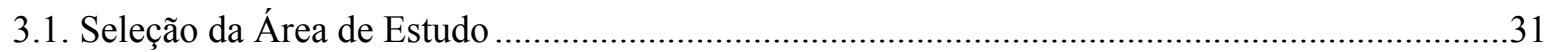

3.2. Identificação e Caracterização das Feições Erosivas ...................................................................33

3.3. Mensuração da Declividade e da Área de Contribuição ................................................................36

3.4. Definição dos Limites Críticos Topográficos .................................................................................39

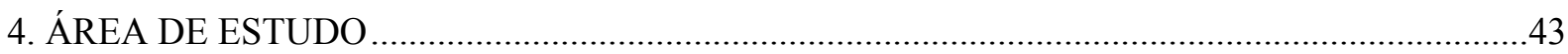

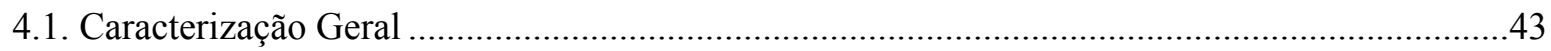

4.2. Voçorocas na Bacia Sedimentar do Paraná e na Região de Bauru..............................................49

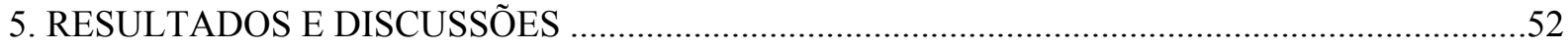

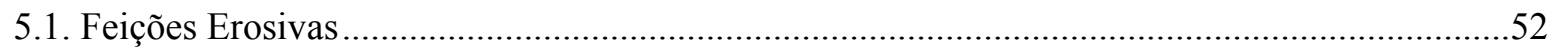

5.2. Comparação dos Métodos de Mensuração da Declividade e da Área de Contribuição ...............70

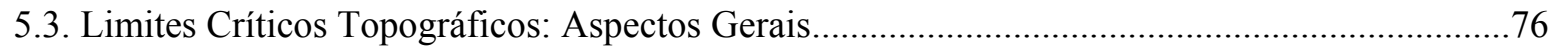

5.4. Limites Críticos Topográficos: Instabilidade e Estabilidade das Feições Erosivas .....................82

5.5. Limites Críticos Topográficos: Deflagração das Voçorocas.........................................................87

5.6. Limites Críticos Topográficos: Classificação das Feições Erosivas ............................................90

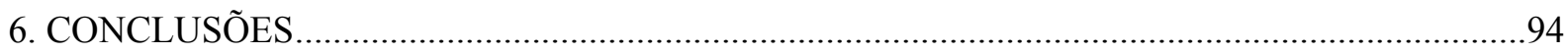

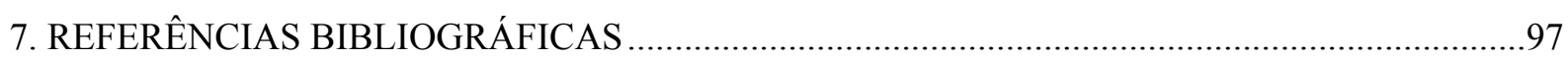




\section{INTRODUÇÃO, JUSTIFICATIVA E OBJETIVOS}

As maiores mudanças na paisagem e as alterações nos padrões de erosão e de deposição são produzidas por alterações climáticas, por controle tectônico ou pela influência do homem (SCHUMM, 1973; 1979). A identificação destas mudanças, na escala de tempo e espaço atuais, demanda a predição e a explicação de aspectos geomorfológicos que são de real significância para a compreensão da dinâmica da paisagem, como, por exemplo, os voçorocamentos modernos (SCHUMM, 1973; 1979).

Diversos autores como SCHUMM (1973; 1979); CAMPBELL e HONSAKER (1982); OOSTWOUD WIJDENES e BRYAN (1991); OLIVEIRA e QUEIROZ NETO (1993); RITTER et al. (1995) e SIDORCHUK (1999; 2006) entendem os sistemas de voçorocamento como sinais da instabilidade geomorfológica, seja por fatores naturais ou pela ação antrópica. A compreensão desta dinâmica, todavia, perpassa pelo entendimento dos processos que atuam na formação da erosão linear (voçorocas), como o escoamento superficial, a erosão em túnel (piping) e os movimentos de massa; na determinação dos fatores controladores predominantes; e, na caracterização dos ciclos de estabilidade e instabilidade das voçorocas (gullies) (OOSTWOUD WIDJENES e BRYAN, 1991; KIRKBY e BRACKEN, 2009).

Para POESEN et al. (2003) uma das principais questões que devem ser respondidas pelas pesquisas em erosão linear (gullying) é se é possível identificar condições críticas para a iniciação, desenvolvimento e estabilização de voçorocas em diferentes ambientes em termos de fluxos hídricos, chuva, topografia, solos e uso do solo.

Objetivando definir o limite crítico topográfico para a ocorrência de processos de erosão linear, diversos autores como PATTON e SCHUMM (1975), VANDAELE et al. (1996), MORGAN e MNGOMEZULU (2003) e VANWALLEGUEM et al. (2005) têm buscado a identificação destes limiares a partir da abordagem denominada SA (Slope x Area ou Declividade x Área de Contribuição), cujos principais pressupostos foram consolidados por MONTGOMERY e DIETRICH (1988; 1989; 1994) e DIETRICH et al. (1992; 1993).

De acordo com MONTGOMERY \& DIETRICH (1994) a abordagem SA possibilita definir os limiares entre a predominância de processos difusos na paisagem e a iniciação de canais, de modo que a relação entre área de contribuição e declividade fornece um quadro conceitual para investigar a resposta da paisagem a mudanças. No entanto, os trabalhos realizados até hoje se limitaram a avaliar apenas os limites críticos da iniciação de canais (erosão linear), sendo praticamente ausentes estudos que estimam os limites que definem a 
estabilidade das feições, ou como afirmam POESEN et al. (2003), poucas relações entre declividade e área de contribuição têm sido delineadas para a localização de onde as feições erosivas lineares terminam.

Considerando também que as voçorocas são frequentemente caracterizadas como formas de comportamento complexo, como corroboram JUNGERIUS e VAN DEN BRINK (1991), BRYAN (2000), VANWALLEGUEM et al. (2005), AUGUSTIN e ARANHA (2006) e SIDORCHUK (2006), a identificação dos limites críticos topográficos a partir da abordagem SA demanda um razoável entendimento das formas erosivas existentes em um certo local, incluindo seus principais processos de desenvolvimento e os respectivos fatores controladores. Trata-se de uma metodologia pouco explorada no Brasil, em especial sob litologia sedimentar, o que motiva ainda a possibilidade de comparação entre os processos erosivos ocorrentes neste meio e os estudos realizados por outros autores sob condições ambientais diversas.

O município de Piratininga localiza-se na região de Bauru (SP), cujos processos erosivos existentes, em especial as voçorocas, foram densamente estudados por SALOMÃO (1994) quanto aos seus aspectos hidrológicos e pedológicos. Essas feições erosivas, deflagradas após a remoção da cobertura vegetal original (SALOMÃO, 1994; CASTRO e QUEIROZ NETO, 2009), evoluíram a partir de diversos processos, movidos principalmente pela dinâmica das águas subsuperficiais, e atualmente encontram-se próximas da estabilização. Outros estudos na região (STABILE, 2009; STABILE e VIEIRA, 2009a, 2009b), já demonstraram a relação entre as feições erosivas lineares e os parâmetros topográficos, principalmente com a declividade e com as curvaturas de encosta côncavas em planta. Logo, o objetivo geral desta pesquisa é avaliar os limites críticos topográficos para o desenvolvimento das formas resultantes da erosão linear em Piratininga (SP). Os objetivos específicos consistem em:

a) Identificar e caracterizar as feições erosivas lineares a partir de indicadores de sua dinâmica e desenvolvimento (ex. forma em planta, sinais de escoamento superficial, piping; sinais de solapamento ou rachadura nas cabeceiras e laterais)

b) Comparar os métodos de mensuração da declividade (campo e Modelo Digital de Terreno) e área de contribuição (diferentes resoluções de Modelo Digital de Terreno);

c) Analisar a relação entre os limites críticos topográficos e a estabilidade/instabilidade das feições erosivas lineares, assim como com sua dinâmica de desenvolvimento. 


\section{FUNDAMENTAÇÃO TEÓRICO-METODOLÓGICA E CONCEITUAL}

A avaliação dos limites críticos topográficos para o desenvolvimento das formas resultantes da erosão linear demanda o conhecimento de alguns alicerces teóricos que são fundamentais para a compreensão do fenômeno. Visando elucidar essas questões, este capítulo inicialmente trata do conceito de erosão linear e das noções de estabilidade e instabilidade das feições erosivas (item 2.1). Na sequência, a fim de demonstrar a complexidade das formas erosivas lineares, é feita uma revisão bibliográfica dos principais processos associados ao desenvolvimento de feições erosivas e seus fatores controladores dominantes (2.2), assim como se descreve brevemente os diversos modos de classificação da erosão linear (2.3). Posteriormente, são abordados os aspectos teóricos do conceito de limite crítico e sua dependência das escalas temporal e espacial na análise geomorfológica (2.4). Em seguida, é apresentada a abordagem Declividade - Área de Contribuição como um dos métodos disponíveis para a definição de limiares geomorfológicos (2.5), para enfim avaliar as questões metodológicas envolvidas no uso dessa abordagem e sobre os exemplos de suas aplicações no estudo da erosão linear (2.6).

\subsection{O Conceito de Erosão Linear}

A erosão linear (gully erosion) é considerada como um processo erosivo resultante da acumulação do runoff, promovendo a remoção do solo de um local em profundidades consideráveis (POESEN et al., 2003). Portanto, a convergência do escoamento da água (por exemplo, em uma concavidade pré-existente, linhas de cultivo, estradas, etc.) é fundamental para sua formação (KIRKBY e BRACKEN, 2009).

KIRKBY e BRACKEN (2009) estabelecem que para as feições erosivas lineares se sustentarem e se desenvolverem, elas demandam algumas peculiaridades morfológicas essenciais, como o leito com inclinação menor que o da superfície na qual elas incidem e cabeceiras relativamente abruptas, para permitir o desenvolvimento remontante da feição; processos de canal (streamflow) com capacidade para transportar todo o material erodido de sua expansão e de sua bacia de contribuição; e, paredes laterais íngremes, pois estas ajudam a minimizar o volume de material que deve ser transportado para a expansão da feição.

Atribui-se às feições erosivas lineares a função, em associação com outros processos geomorfológicos, de equacionar a geometria do sistema (formas de relevo) aos novos inputs de matéria e de energia de uma situação de instabilidade. Consequentemente, as feições 
erosivas lineares (ravinas e voçorocas) são comumente descritas como sinais de instabilidade dos sistemas geomorfológicos (SCHUMM, 1973; 1979; CAMPBELL e HONSAKER, 1982; OOSTWOUD WIJDENES e BRYAN, 1991; OLIVEIRA e QUEIROZ NETO, 1993; RITTER et al., 1995; SIDORCHUK, 1999; 2006). OOSTWOUD WIDJENES e BRYAN (1991) descrevem que a instabilidade pode ser causada, por exemplo, por:

- Chuvas intensas, mudanças climáticas ou mudanças na hidrologia da bacia hidrográfica resultando em aumento da vazão de pico;

- Redução da resistência da superfície devido à remoção da vegetação ou mudanças nas propriedades físicas e químicas do solo; e,

- Mudanças nas condições hidráulicas causadas pela diminuição do nível de base.

Os fatores causais (motores) dessa instabilidade advêm tanto de origens que podem ser chamadas de naturais como pela ação direta do homem. TANAKA e AGATA (2002), por exemplo, relatam que há cerca de 6.000 anos em Soya Hills, no norte do Japão, o incremento da pluviosidade sobre uma cobertura vegetal, então escassa, e depósitos inconsolidados promoveram a evolução da rede de canais pela erosão linear (gully erosion). Os autores descrevem também que hoje, com a cobertura florestal desenvolvida, a erosão linear tornou-se inativa. OOSTWOUD WIDJENES e BRYAN (1991), por sua vez, expõem que em Eldume, no Quênia, o rebaixamento do nível de base do rio Molo deflagrou sistemas de voçorocamentos profundos configurados como badlands. Por outro lado, a maior parte dos trabalhos que analisam formas erosivas atuais, em uma ampla gama de ambientes, atribui ao menos a intensificação do desenvolvimento de ravinas e voçorocas à atuação antrópica, como os trabalhos de JUNGERIUS e VAN DEN BRINK (1991) no Marrocos, SALOMÃO (1994) no Platô de Bauru (SP), CASALÍ et al. (1999) em Navarra no sul da Espanha, MORGAN e MNGOMEZULU (2003) no Middle Veld da Suazilândia, CASTRO (2005) na alta bacia do rio Araguaia (GO, MT), LOHMANN e SANTOS (2005) no rebordo do Planalto Sul-RioGrandense em São Pedro do Sul (RS) e VANWALLEGUEM et al. (2005) no Loess Belt belga.

A fase inicial da evolução das feições, por conseguinte, é marcada pela erosão intensa e as suas características morfológicas estão longe de serem consideradas constantes, predominando processos de incisão e de alargamento do canal erodido, movimentos de massa nas paredes laterais e crescimento da cabeceira (SIDORCHUK, 2006). Entre os principais indicadores de atividade erosiva podem-se citar as evidências de solapamento nas cabeceiras e 
as rachaduras de tensão nas bordas das cabeceiras e paredes laterais, as quais promovem movimentos de massa que aumentam a largura e o comprimento das feições (SIDORCHUK, 1999, 2006; VANDEKERCKHOVE et al., 2000).

Quando as formas são equacionadas à nova dinâmica do sistema, as feições erosivas se estabilizam (atingem o Equilíbrio Dinâmico) e suas características e processos são compatíveis à nova condição. A reduzida erosão atuante concentra-se nas cabeceiras e ocorre o crescimento da vegetação no interior da feição, sendo esta uma das principais expressões da estabilidade das feições erosivas lineares (SIDORCHUK, 1999, 2006). Para KIRKBY e BRACKEN (2009), entre os fatores que promovem a estabilização ou que restringem a erosão nas feições erosivas estão: a área de contribuição, ou seja, à medida que a feição se desenvolve remontantemente ela limita a bacia disponível; a capacidade de transporte do seu leito, ou seja, se sedimentos muito grosseiros ou em excesso atingem a feição e esta não consegue transportá-los, sua taxa de incisão torna-se negativa; e, o alcance do nível de base local que controla a incisão, ou seja, uma vez que a feição atinja o seu nível de base local, ela deve cessar, permitindo a estabilização de seu leito e a ampliação e suavização das paredes laterais.

Apesar de muitos estudos sobre feições erosivas lineares apresentarem inúmeros indicadores da sua instabilidade e estabilidade, até hoje poucos estudos trataram de definir efetivamente os limites entre os estados instável e estável da erosão linear. SIDORCHUK (2006), em um dos poucos trabalhos que buscaram definir um limite entre as duas condições, afirma que o entendimento teórico do estado estável das feições erosivas lineares (gullies) deve ser baseado no paradigma do equilíbrio dinâmico. Assim, o equilíbrio é associado a uma taxa negligível do fluxo de sedimentos na feição (tanto erosão como sedimentação do seu leito), sendo a forma erosiva vista como um conduto para o transporte de água e de sedimentos da sua bacia de contribuição, sem alterações significativas na morfologia do seu sistema de transporte. Para o autor, a compreensão da feição erosiva no estágio ativo é menos nítido, apesar de ser claro que sua deflagração está vinculada a uma condição crítica e que o processo de gullying no estágio ativo está longe do equilíbrio, de modo que o tamanho da feição (comprimento, profundidade, área e volume) aumenta rapidamente com o tempo. De acordo com SIDORCHUK (1999, 2006), apesar do estágio ativo constituir apenas cerca de $5 \%$ do tempo de vida de uma gully, mais de $90 \%$ do comprimento da feição, $60 \%$ de sua área e $35 \%$ do seu volume são formados neste período. 
Ainda que os estados instável e estável dos processos erosivos lineares apresentem características dinâmicas gerais bem diferentes, sobretudo no que tange à magnitude e frequência dos subprocessos associados (SIDORCHUK, 2006), eles parecem ser separados por uma transição gradual, de maneira que a indicação do momento exato da passagem de um estado ao outro, ao menos por meio dos dados existentes atualmente, seria meramente subjetiva. Para uma maior compreensão dos estágios de evolução do processo é necessária uma discussão dos seus subprocessos e seus fatores controladores.

\subsection{Erosão Linear: Fatores Controladores e Processos Envolvidos}

As voçorocas ou gullies são frequentemente caracterizadas como formas de comportamento complexo, como corroboram VIEIRA (1978), FURLANI (1980), JUNGERIUS e VAN DEN BRINK (1991), BRYAN (2000), VANWALLEGUEM et al. (2005), AUGUSTIN e ARANHA (2006) e SIDORCHUK (2006). Este comportamento complexo é fruto dos diversos processos que atuam na sua gênese e desenvolvimento e que, de acordo com BULL e KIRKBY (1997) e AUGUSTIN e ARANHA (2006), incluem o escoamento superficial, a erosão em túnel (piping) e movimentos de massa.

\subsubsection{Escoamento Superficial}

BULL e KIRKBY (1997) apontam que a erosão por escoamento superficial ocorre quando a taxa pluviométrica é suficiente para produzir runoff e quando a tensão cisalhante (dependente do impacto das gotas de chuva, da declividade da encosta e da profundidade da lâmina d'água) produzida pela água em movimento excede a resistência da superfície do solo. A resistência da superfície do solo (e a erodibilidade ou capacidade do solo de ser erodido), por sua vez, está relacionada à litologia, textura, estabilidade dos agregados, coesão, proteção pela cobertura vegetal, etc. (HORTON, 1945; BULL e KIRKBY, 1997; SIDORCHUK, 1999) (Figura 1). BRYAN (2000), porém, lembra que a erodibilidade dos solos deve ser entendida como um fator dinâmico, visto que propriedades importantes como a resistência ao cisalhamento e a estabilidade dos agregados alteram-se em ciclos temporais curtos e longos de variada magnitude e previsibilidade. 

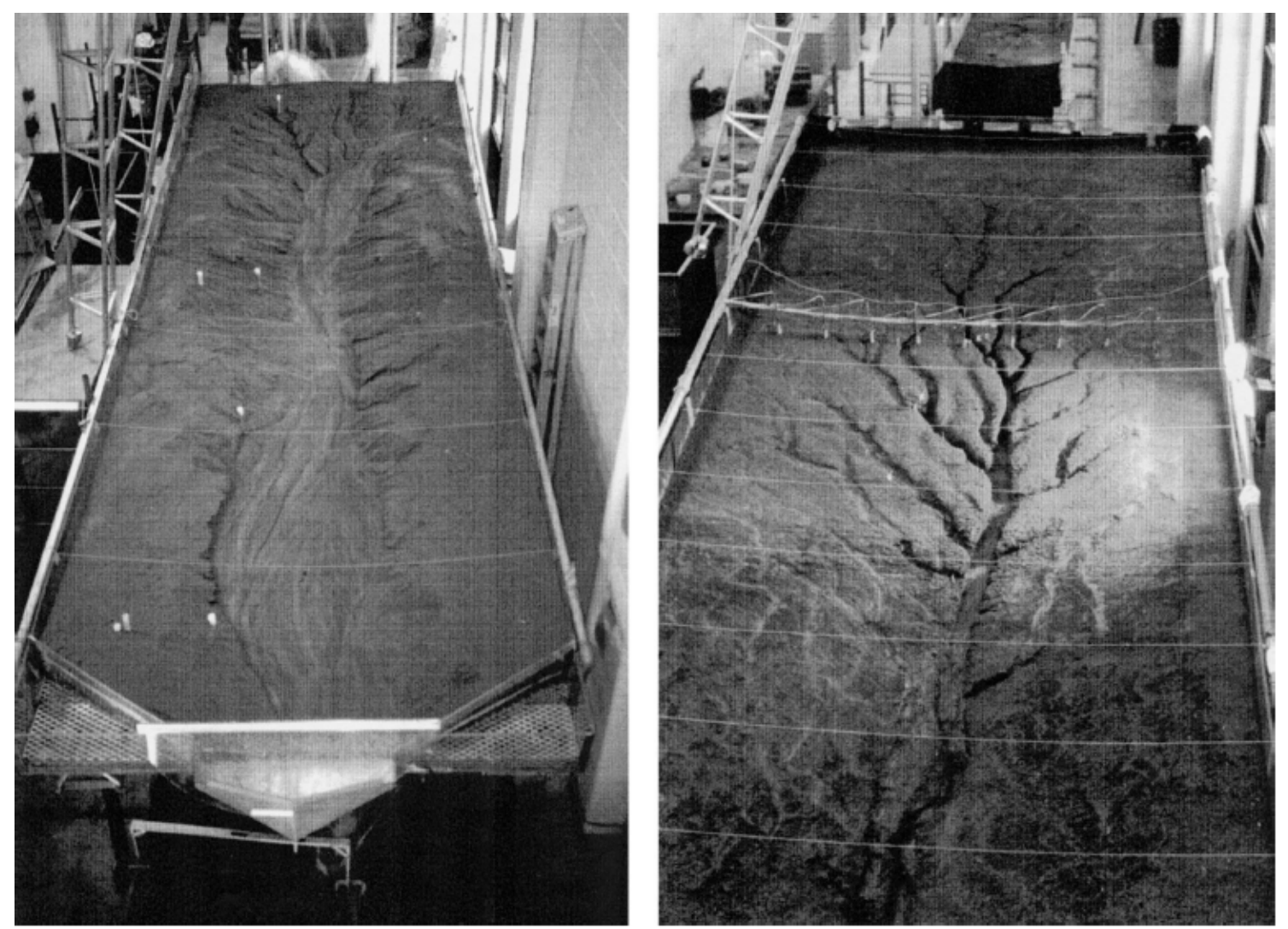

Figura 1: Desenvolvimento de redes de sulcos em diferentes tipos de solo após 2 horas de simulação de chuva a $60 \mathrm{~mm} \mathrm{~h}^{-1}$. A calha da esquerda está preenchida por solo franco-arenoso e o desenvolvimento dos canais foi fortemente influenciado pela umidade da subsuperfície e pela água de percolação, enquanto a calha da direita está preenchida com solo franco-siltoso e altamente coesivo. BRYAN (2000)

Também sobre o escoamento da água, OOSTWOUD WIJDENES e BRYAN (1991), referindo-se às gullies de Lameluk (Quênia), ressaltam a importância do padrão pluviométrico e da variação sazonal da cobertura vegetal (cultivos agrícolas) na descarga de runoff que promove o desenvolvimento das feições erosivas lineares, e, VANWALLEGUEM et al. (2005), analisando as gullies da Bélgica central, destacam os elementos lineares da paisagem (sulcos de arado, estradas de acesso, valas de drenagem, etc.) como promotores da concentração do escoamento superficial e, por conseguinte, da incisão de feições erosivas lineares.

Diversos autores sustentam que a proeminência do escoamento superficial na atividade das feições erosivas faz com que estas feições apresentem características específicas. Segundo SIDORCHUK (1999) e VANWALLEGUEM et al. (2005), por exemplo, as feições erosivas formadas por fluxo superficial hortoniano são caracterizadas por um perfil lateral retangular. SOBREIRA e BACELLAR (1999), por sua vez, referindo-se às voçorocas da região de Ouro Preto $(\mathrm{MG})$, descrevem que as feições com maior importância da ação das águas superficiais 
no seu desenvolvimento têm forma dendrítica, com ravinas partindo a montante de seu corpo principal. OOSTWOUD WIJDENES et al. (1999) expõem que, em Sierra de Gata (sudeste espanhol), cabeceiras de feições erosivas formadas pela predominância do escoamento superficial inicialmente são graduais, ou seja, não são abruptas.

BULL e KIRKBY (1997) argumentam que um dos principais mecanismos do escoamento superficial na evolução de cabeceiras íngremes de feições erosivas é a erosão em plunge pool, que ocorre quando o escoamento encontra uma ruptura de declive, produz uma queda d'água e, consequentemente, uma plunge pool (alcova). Na alcova ocorre o turbilhonamento da água, promovendo o solapamento das paredes da feição erosiva, e os sedimentos carreados para fora da plunge pool criam uma saliência a sua jusante, definindo sua forma.

PAISANI e OLIVEIRA (2001) indicaram a ocorrência desse mecanismo em uma voçoroca descontínua em Palmeira (PR). Eles propõem que as descontinuidades (degraus) da voçoroca estariam associadas uma rede de terracetes (resultantes do pisoteio do gado) perpendiculares à inclinação da encosta, que convergem para a zona côncava na qual se instalou a incisão. Assim, o escoamento proveniente destes terracetes seria tão importante quanto o escoamento proveniente das cabeceiras na erosão da feição, criando zonas de concentração de escoamento turbulento nos degraus, que são marcados por depressões de forma cilíndrica que os autores denominam de marmitas (correspondem ao termo plunge pool). Ao passar pela ruptura de declive originada dos degraus, o escoamento formaria pequenas cachoeiras e zonas de turbilhonamento, que seriam os responsáveis pela criação e aprofundamento das marmitas. Por fim, PAISANI e OLIVEIRA (2001) descrevem que ao sair destas zonas de turbilhonamento a água se espraiaria por uma superfície mais ampla, reduzindo a competência e a capacidade do fluxo, o que resultaria na deposição do material erodido e na consequente formação dos depósitos aluviais. Conforme a Figura 2, que esquematiza a dinâmica desta feição erosiva, os processos de sua evolução incluem ainda uma zona de rastejo nos terracetes da cabeceira da incisão e a erosão por percolação.

Além deste, outros estudos que confirmam a erosão em alcovas de regressão (plunge pool) são os trabalhos de FURLANI (1980), nas voçorocas de Casa Branca (SP), que relaciona o fenômeno ao recuo das paredes de patamares (replats) nas feições, de OOSTWOUD WIJDENES et al. (1999), em feições erosivas de Sierra de Gata, sudeste espanhol, no qual os autores associam a erosão da plunge-pool à evolução remontante de feições erosivas com cabeceiras abruptas a partir de um nível de base local (knickpoint), e de 
DRUMOND e BACELLAR (2006), que associam as alcovas ao escoamento superficial concentrado proveniente de trilhas de pisoteio de gado em uma voçoroca no município de Itabirito (MG).

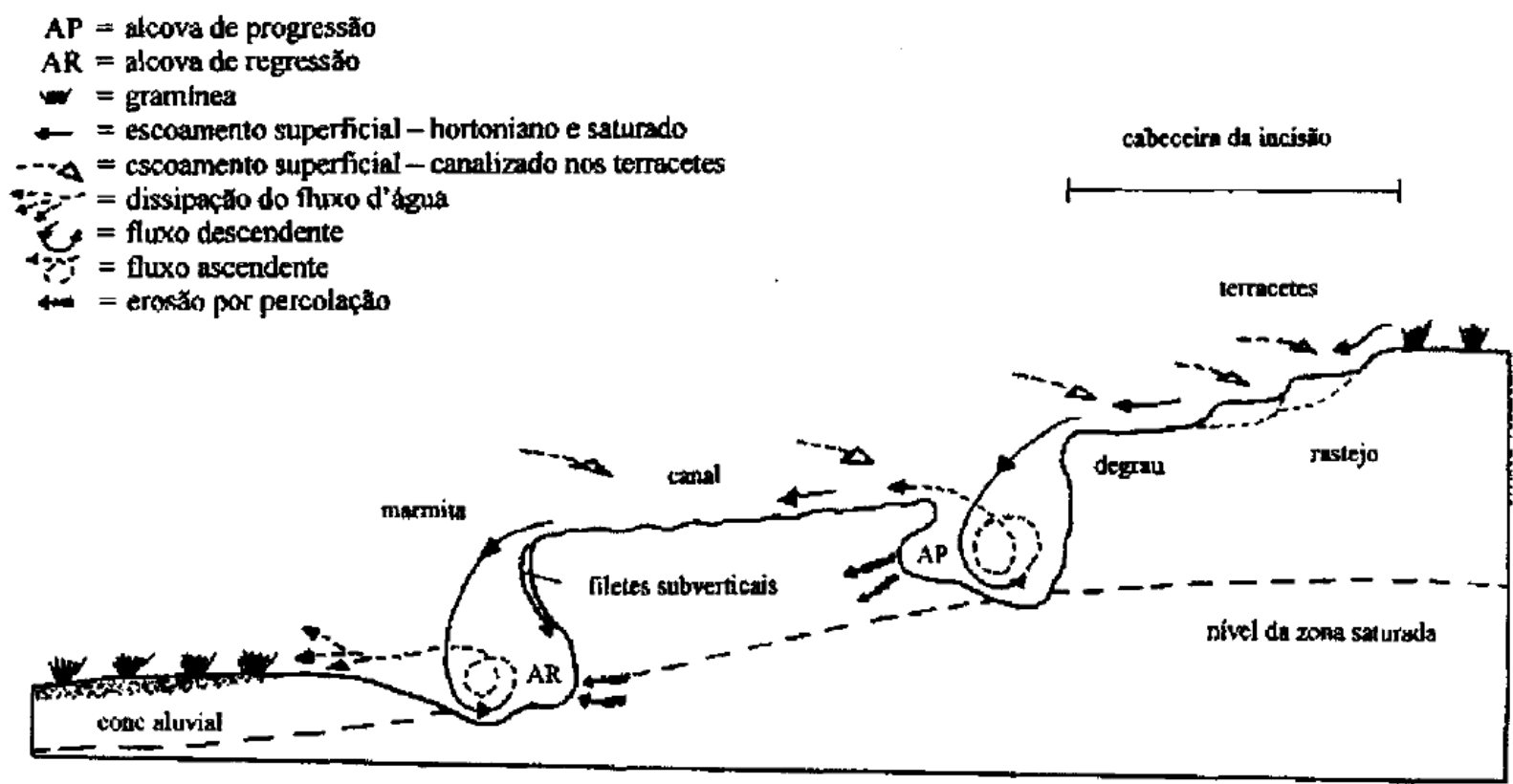

Figura 2: Esboço da atuação dos processos erosivos em uma voçoroca descontínua e desconectada da rede de drenagem na Colônia Quero-Quero, Palmeira (PR). Modificada de PAISANI e OLIVEIRA (2001).

Outro mecanismo que pode ocorrer no desenvolvimento das feições erosivas lineares pelo escoamento superficial é a formação de caneluras (fluting). VANDEKERCKHOVE et al. (2000) e VANWALLEGUEM et al. (2005) definem o fluting como o desenvolvimento vertical de estrias (flutes ou caneluras) alongadas e afuniladas para cima na face dos taludes das feições erosivas, sendo resultantes predominantemente da ação da água corrente, mas também do escoamento subsuperficial (throughflow) em combinação com o impacto das gotas de chuva (Figura 3). O processo de fluting envolve uma seqüência de estágios que se iniciam com a formação de sulcos em uma face planar juntamente com o transporte do material removido, perpassando pelo desenvolvimento dos flutes e chegando, por fim, a sua destruição (por solapamento e queda), culminando no recuo das paredes das feições erosivas (VANDEKERCKHOVE et al., 2000). 


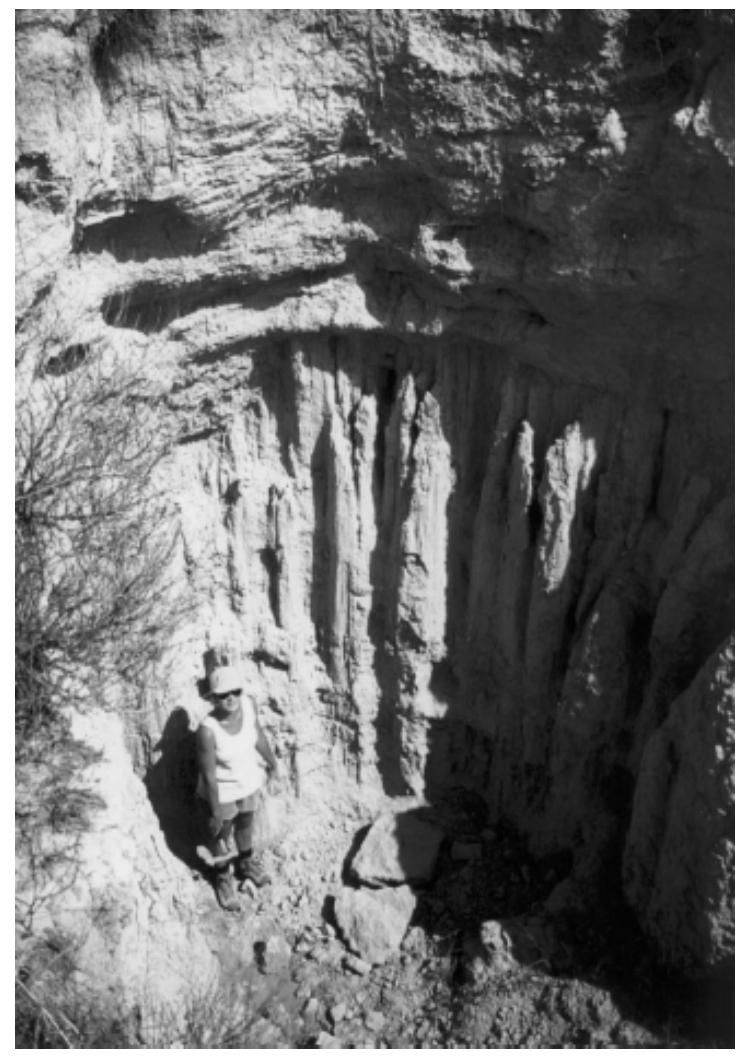

Figura 3: Ocorrência de fluting na cabeceira de uma bank gullie em Guadalentin (Espanha). VANDEKERCKHOVE et al. (2000).

Os autores associam a formação de caneluras em feições erosivas de Guadix e Guadalentin (sudeste da Espanha) a um horizonte subjacente mais friável, responsável pelo recuo por solapamento de uma camada de solo superior mais resistente. Nestas feições os autores encontraram uma correspondência entre o fluting e a maior dispersividade dos solos. Outros autores, como SOBREIRA e BACELLAR (1999) e VANWALLEGUEM et al. (2005), também descrevem a ocorrência desse processo em horizontes subsuperficiais: os primeiros no horizonte $\mathrm{C}$ dos solos nas voçorocas de Ouro Preto (MG) e, os últimos, em horizontes calcários a cerca de 0,4 metros da superfície em gullies na Bélgica central. 


\subsubsection{Piping}

O piping é um processo erosivo normalmente descrito como a formação de túneis pelo escoamento subsuperficial da água, que remove pequenos grãos e colóides do solo por carreamento mecânico ou solução (BULL e KIRKBY, 1997; JONES et al., 1997; FAULKNER et al., 2004; AUGUSTIN e ARANHA, 2006), sendo um processo frequentemente associado à formação e desenvolvimento de feições erosivas lineares (BULL e KIRKBY, 1997). OOSTWOUD WIJDENES e BRYAN (1991), por exemplo, relataram que o piping (ou erosão em túnel) é um dos indutores da gênese e evolução de feições erosivas do tipo badlands em Eldume (Quênia) e de gullies pequenas e rasas em Marigat Airstrip (Quênia). COELHO NETTO (2003) descreve o piping como um dos responsáveis pelo desenvolvimento de voçorocas nas cabeceiras do médio vale do Rio Paraíba do Sul (SP/RJ), enquanto AUGUSTIN e ARANHA (2006), ressaltam que este constitui um dos processos mais importantes no recuo das cabeceiras, no alargamento das paredes e no aumento no número de ramificações das voçorocas de Gouveia (MG).

BULL e KIRKBY (1997) relatam que, uma vez que o pipe existe, os problemas de remoção do solo pelo piping são similares ao transporte de sedimentos em canais abertos, pois quando o fluxo d'água deixa de seguir as Leis de Darcy entre os macro-poros, ele se acelera, especialmente em altos gradientes hidráulicos. O alargamento dos túneis e a diminuição da espessura do seu teto podem levar ao seu colapso, ocorrendo a exposição e coalescência dos pipes em feições lineares, de modo que estas feições passam então a ser controladas também pelo escoamento superficial e movimentos de massa (BULL e KIRKBY, 1997; AUGUSTIN e ARANHA, 2006).

Os canais originários da erosão em túnel têm normalmente cabeceiras verticais e taludes íngremes, com baixo gradiente no fundo e tendem a ser retilíneos por grandes distâncias entre curvas acentuadas (BULL e KIRKBY, 1997). FAULKNER et al. (2004) acrescentam ainda a ocorrência de descontinuidades na feição, "pontes" e um alto quociente entre profundidade e largura da feição erosiva. Por outro lado, AUGUSTIN e ARANHA (2006) advertem que a comprovação da correlação entre a atuação do piping e o voçorocamento não é uma tarefa fácil, pois nem sempre é possível detectar na superfície evidências de colapso do túnel, uma vez que a ação do escoamento superficial tende a se tornar preponderante, encobrindo estas evidências. 
O piping normalmente está associado a fatores controladores específicos como à maior dispersividade dos solos (OOSTWOUD WIJDENES e BRYAN, 1991; BULL e KIRKBY, 1997; VANDEKERCKHOVE et al., 2000; FAULKNER et al., 2004), à granulometria (VANDEKERCKHOVE et al., 2000), à fendas ou fissuras no solo que facilitam a infiltração da água (BULL e KIRKBY, 1997; AUGUSTIN e ARANHA, 2006), à ocorrência de camadas mais permeáveis sobrejacentes à superfícies relativamente impermeáveis como horizontes iluviais ou saprolitos (SALOMÃO, 1994; JONES et al., 1997; FAULKNER et al., 2004; AUGUSTIN e ARANHA, 2006) e à altos gradientes hidráulicos (OOSTWOUD WIJDENES e BRYAN, 1991; JONES, 1997; VANDEKERCKHOVE et al., 2000). Outros controles citados pela literatura envolvem o aumento da poro-pressão pela água de exfiltração nas paredes das feições erosivas (COELHO NETTO, 2003; POESEN et al., 2003), a influência do pisoteio do gado no colapso do teto dos túneis (OOSTWOUD WIJDENES e BRYAN, 1991) e o índice entre a área de contribuição e a declividade da bacia onde ocorre o processo, ou seja, a relação entre a velocidade e volume d'água, descrita por JONES et al. (1997) na GrãBretanha, que fazem a ressalva de que esta relação não é fixa e que ocorrem algumas variações importantes, visto a heterogeneidade das propriedades do solo e a sua diversa exposição aos fatores climáticos (orientação das encostas).

\subsubsection{Movimentos de Massa}

Entre os processos importantes pela evolução remontante das feições erosivas lineares estão os movimentos de massa (Figura 4). Diversas tipologias de movimentos de massa são descritas em feições erosivas lineares. SOBREIRA e BACELLAR (1999) e DRUMOND e BACELLAR (2006), por exemplo, associam a evolução das paredes e cabeceiras das voçorocas de Ouro Preto $(\mathrm{MG})$ e de Itabirito $(\mathrm{MG})$, respectivamente, a escorregamentos rotacionais, com superfície de ruptura inclinada, vinculados a trincas ou fendas verticais paralelos aos taludes das feições. Este aspecto foi considerado relevante também por OOSTWOUD WIJDENES et al. (1999) na indução de movimentos de massa em taludes de gullies em Sierra de Gata (sudeste espanhol). DRUMOND e BACELLAR (2006) destacam ainda o papel de escorregamentos translacionais ou planares associados às descontinuidades de gnaisses alterados nos taludes da voçoroca, BULL e KIRKBY (1997) relacionam a dinâmica das badlands a escorregamentos translacionais e rotacionais e VIEIRA (1978) associa a dinâmica dos deslizamentos e desmoronamentos nas voçorocas de Franca (SP) ao 
contato entre os sedimentos arenosos superiores e o nível hidrostático ou sedimentos argilosos.

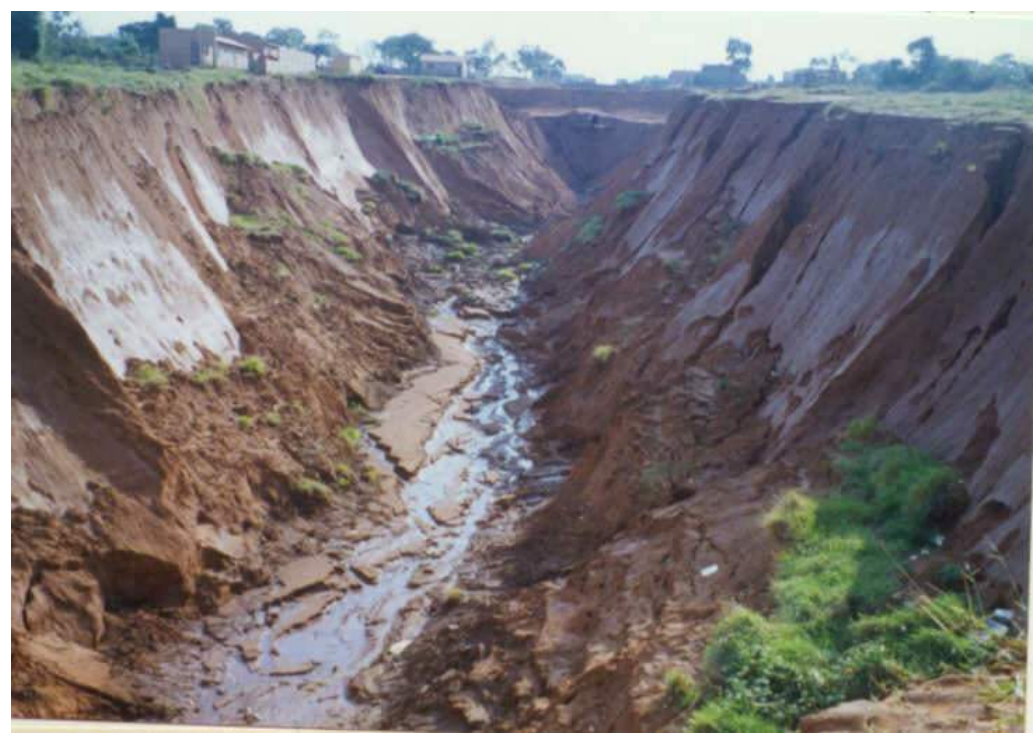

Figura 4: Voçoroca próxima à área urbana de Bauru (SP). Notar os depósitos de sedimentos no sopé dos taludes laterais indicando a ocorrência de movimentos de massa. Fonte: Instituto de Pesquisas Tecnológicas do Estado de São Paulo - IPT/SP.

Outros mecanismos envolvem o solapamento (queda) dos taludes das voçorocas, quando do aumento das vazões do canal interno às feições, conforme relatado por DRUMOND e BACELLAR (2006), movimentos de rastejo no sopé dos taludes, cabeceiras e fundo das feições erosivas lineares (SOBREIRA e BACELLAR, 1999; DRUMOND e BACELLAR, 2006), solapamento do teto dos túneis formados por piping (BULL e KIRKBY, 1997) e quedas de blocos (KIRKBY e BRACKEN, 2009).

Assim como os outros processos envolvidos na dinâmica das feições erosivas lineares, a predominância dos movimentos de massa no seu desenvolvimento resulta em feições com características típicas (SIDORCHUK, 1999; SOBREIRA e BACELLAR, 1999; OOSTWOUD WIJDENES et al., 1999; VANDEKERCKHOVE et al., 2000). SIDORCHUK (1999) afirma que a instabilização das paredes das gullies e os consequentes escorregamentos transformam o perfil lateral das feições de retangular para trapezoidal, em parecer semelhante ao de VANDEKERCKHOVE et al. (2000), que associam os deslizamentos nas paredes das feições à formação de um perfil lateral semicircular. Já SOBREIRA e BACELLAR (1999), propõem que as feições erosivas grosseiramente circulares em planta apresentam como 
característica a existência atual ou pretérita de processos de erosão interna, tendo como resultante o solapamento dos taludes laterais e quedas de blocos.

Avaliados os processos envolvidos na gênese e desenvolvimento de feições erosivas lineares, bem como seus fatores controladores, é possível analisar as classificações existentes e seus preceitos.

\subsection{Classificação das Feições Erosivas Lineares}

Chama a atenção a inexistência de consenso e, sobretudo, a variedade de classificações das feições erosivas lineares. Os sistemas de classificação variam regionalmente, de acordo com o inventário de feições existentes e os métodos disponíveis para seu estudo e, principalmente, conforme os objetivos de quem propõem a classificação.

BULL e KIRKBY (1997) propõem uma classificação que emprega atributos da dinâmica das feições aliados a parâmetros morfométricos subordinados:

- Sulcos (rills): são canais efêmeros que variam lateralmente de ano a ano, normalmente com um ciclo sazonal de desenvolvimento e destruição. Os autores afirmam que os sulcos são inerentemente associados a uma retroalimentação negativa, a qual inibe sua subseqüente formação no mesmo local, de modo que seu efeito cumulativo é rebaixar a encosta mais ou menos uniformemente.

- Canais efêmeros: são canais também não-permanentes, periodicamente destruídos por processos naturais ou pelo manejo do solo, mas diferem dos sulcos, pois tendem a retornar na mesma posição (um segmento topograficamente rebaixado com forma linear ou um local que promova a convergência dos fluxos hídricos).

- Canais permanentes: são canais com margens evidentes e, em alguns casos, uma cabeceira íngreme (headcut). A sua cabeceira marca o limite montante do escoamento concentrado e do transporte de sedimentos entre margens definidas.

POESEN et al. (2003) sugerem uma categorização semelhante à anterior, distinguindo entre voçorocas permanentes (permanent gullies), voçorocas efêmeras (ephemeral gullies) e sulcos (rills). Estes autores incluem ainda o termo voçorocas de margem (bank gullies), para diferenciar aquelas feições que evoluem a partir de uma margem ou talude com alta declividade, daquelas que incidem sobre encostas mais suaves, denominadas voçorocas 
clássicas (classical gullies) (Figura 5). VANWALLEGUEM et al. (2005), por sua vez, individualizaram as voçorocas efêmeras (ephemeral gullies) do Loess Belt da Bélgica em profundas (deep gullies) e rasas (shallow gullies), inicialmente apenas com base em suas dimensões, buscando, por meio do estudo, diferenciá-las quanto à dinâmica e condições de formação, corroborando para a afirmação anterior de que a classificação utilizada muitas vezes é delineada em acordo com o objetivo da análise.

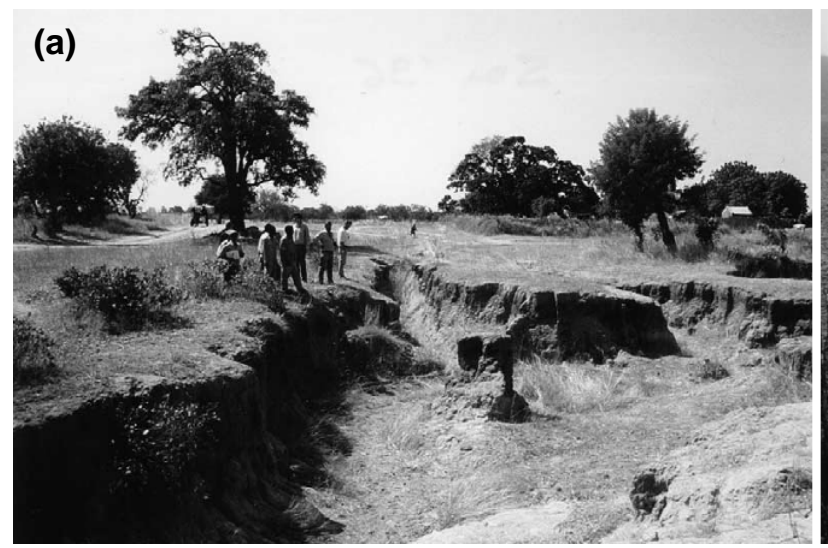

(b)

Figura 5: Permanent (classical) gully em Thysse Kamor (Senegal) (a); e, bank gully em Leefdaal (Bélgica) (b). POESEN et al. (2003).

No Brasil, em especial, as feições erosivas lineares são normalmente divididas em sulcos, ravinas e voçorocas (DAEE/IPT, 1990; GUERRA, 1994; SALOMÃO, 1994; NAKASHIMA, 1999; ALMEIDA FILHO, 2000; CANIL, 2000; SALGADO et al., 2008). Apesar da existência de diferenças nas definições destas feições, estas podem ser assim sintetizadas:

- Sulcos: feições de pequenas dimensões resultantes do escoamento concentrado da água na encosta, facilmente corrigidas pelo manejo do solo.

- Ravinas: feições alongadas resultantes do escoamento concentrado da água na encosta, onde atuam processos de desprendimento de material no seu leito e taludes pela concentração das águas superficiais. Estas feições ocorrem desconectadas da rede de drenagem.

- Voçorocas: feições com paredes laterais íngremes e, em geral, fundo plano, caracterizadas pela atuação, além de processos erosivos superficiais, de processos resultantes do escoamento d'água de subsuperfície que contribuem para que estas feições atinjam grandes dimensões. Para DAEE/IPT (1990), SALOMÃO (1994) e ALMEIDA FILHO (2000) é característica intrínseca destas feições o afloramento do 
lençol freático no seu leito. Em geral, as voçorocas estão associadas aos eixos de drenagem, mas podem ocorrer também isoladamente nas encostas.

No tocante à classificação de feições erosivas cabe lembrar ainda o trabalho de JUNGERIUS e VAN DEN BRINK (1991), que utilizaram um modelo de unidades de relevo para individualizar os componentes de uma feição erosiva (gully) no Marrocos, com base nos processos predominantes atualmente. Deste modo, a feição em análise foi dividida em: encostas de erosão, encostas de transporte, encostas de acumulação e aluviões, cada qual predominando em posições específicas da gully, tanto lateralmente como longitudinalmente, assim como relacionadas com seus processos e materiais principais.

Outra maneira largamente explorada de elencar as feições erosivas lineares, suas formas e processos predominantes, refere-se ao uso de indicadores, ou seja, formas e características atuais que permitem inferir, em maior ou menor grau, a gênese e a dinâmica dominante na evolução das feições. Alguns destes indicadores foram discutidos no item 2.3, quando relacionados a processos específicos. Todavia, é relevante a descrição de parte daqueles e de outros indicadores que podem ser convenientes para a compreensão das feições erosivas em geral:

- Quociente largura-profundidade (width-depth ratio - WDR): utilizado como indicador dos processos predominantes na gênese e desenvolvimento de feições erosivas, assim como do seu estágio evolutivo. Segundo CASALÍ et al. (1999), ao analisarem as feições erosivas efêmeras de Navarra (Espanha), valores de WDR maiores que 1 (feições mais largas) indicam que as feições foram formadas em eventos pluviométricos intensos e curtos, enquanto que valores de WDR menores que 1 (feições mais estreitas), estão associados a feições desenvolvidas durante chuvas mais freqüentes, de longa duração e menos intensas. VANDEKERCKHOVE et al. (2000), por outro lado, ao estudarem feições erosivas marginais (bank gullies) no sudeste espanhol, afirmam que maiores valores de WDR estão associados à predominância do processo de alargamento da feição por recuo das paredes laterais, em detrimento da incisão linear, indicando um estágio mais maduro de evolução da erosão.

- Taxa de aumento da feição: está relacionada à estabilidade e instabilidade de feições erosivas. WU e CHENG (2005) utilizaram como parâmetro as taxas de aumento no comprimento das feições erosivas. Já MARTÍNEZ-CASASNOVAS (2003) e DRUMOND e BACELLAR (2006), além das medições relativas ao comprimento, incluíram as taxas de aumento na área da voçoroca estudada. Em geral, as medidas de 
área (ou volume) estão associadas a estudos que tratam da geração de sedimentos nas feições, enquanto as análises que enfocam as taxas de avanço no comprimento das feições têm interesse no avanço da rede de canais.

- Forma do perfil lateral: VANWALLEGUEM et al. (2005) sugerem que as feições erosivas formadas por fluxo superficial Hortoniano (Hortonian overland flow) têm um perfil lateral retangular, enquanto que aquelas formadas por fluxos d'água resultantes da exfiltração (exfiltration runoff) têm perfil lateral semicircular, resultado da força das águas infiltradas (seepage forces) que provocam o deslizamento das paredes laterais das feições erosivas. SIDORCHUK (1999) segue uma interpretação parecida, definindo, porém, que a atuação de escorregamentos torna o perfil lateral das feições trapezoidal.

- Forma em planta: SOBREIRA e BACELLAR (1999) alegam que a forma em planta das feições erosivas relaciona-se a sua dinâmica pretérita e atual. Os autores propõem, por exemplo, que as feições dendríticas se caracterizam pela maior importância da ação das águas superficiais no seu desenvolvimento, enquanto que as formas erosivas grosseiramente circulares caracterizam-se pela existência atual ou pretérita de processos de erosão interna, tendo como resultante o solapamento das laterais e queda de blocos (Figura 6). VIEIRA (1978), por outro lado, descreve que a forma em planta das voçorocas de Franca (SP) pode estar vinculada a seu estágio de evolução, sendo inicialmente alongadas, depois ramificadas quando a feição é mais ativa e, por fim, circulares, além de que a forma pode estar relacionada ao tipo de encosta em que a feição incide.

- Morfologia da cabeceira: a morfologia das cabeceiras pode ser utilizada como um indicador tanto dos processos atuais como do estágio evolutivo da feição erosiva. De acordo com o estudo de OOSTWOUD WIJDENES et al. (1999), as cabeceiras graduais estariam associadas a um estágio mais inicial da evolução da feição no qual predominam processos de escoamento superficial, enquanto que as cabeceiras abruptas estariam relacionadas à formação de um nível de base local e ao desenvolvimento remontante da feição por movimentos de massa (Figura 7). 

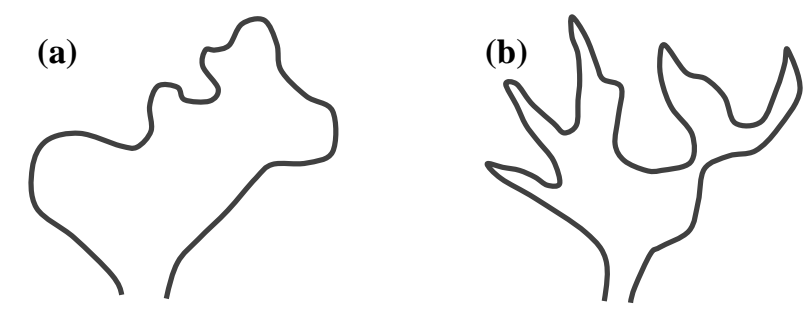

(c)

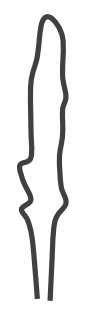

(d)

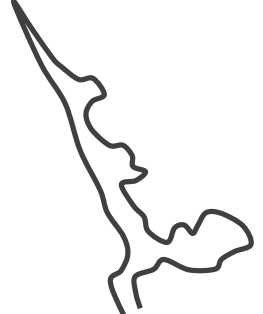

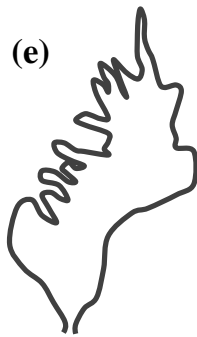

Figura 6: Forma em planta das feições erosivas da região de Ouro Preto (MG): circulares (a), dendríticas (b), com condicionamento antrópico (c) e (d), e com cristas estáveis no interior (e). Modificada de: SOBREIRA e BACELLAR (1999).

(a)
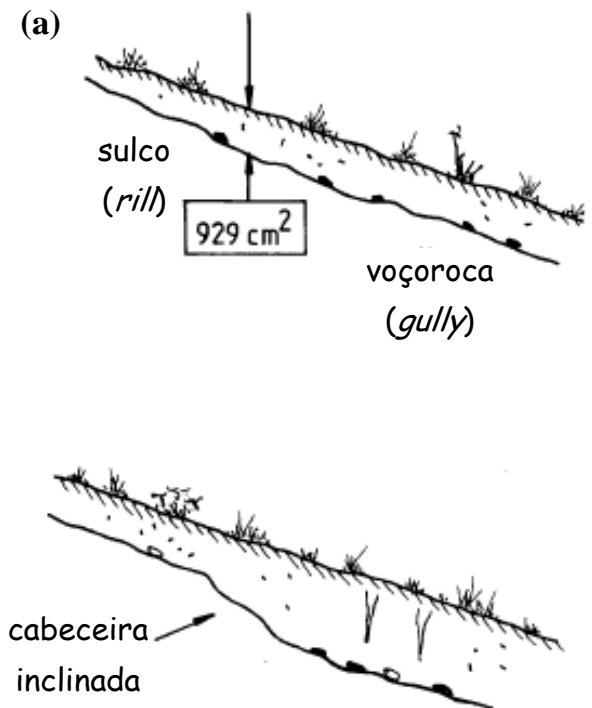

(b)
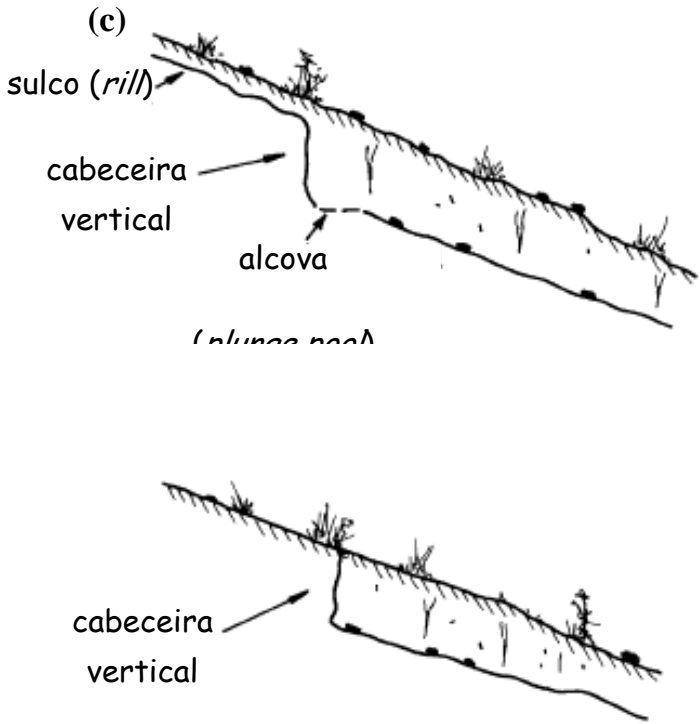

Figura 7: Morfologia das cabeceiras das gullies de Sierra de Gata (Espanha): gradual (a área da seçãotransversal de $929 \mathrm{~cm}^{2}$ foi utilizada como limite entre a feição rill e a feição gully) (a), transicional (b), sulcadaabrupta (c), abrupta (d). Modificada de: OOSTWOUD WIJDENES et al. (1999). 
Tendo em vista os inúmeros modos de se classificar as feições erosivas lineares e que a diversidade entre os conjuntos de feições representa, na verdade, um continuum, POESEN et al. (2003) concluem que qualquer classificação de formas hidraulicamente relacionadas em diferentes categorias é, em certa medida, subjetiva. Apesar disso, quando subsidiada por um rol razoável de informações sobre a morfologia ou os processos atuantes nas feições erosivas lineares, a categorização tende a ter grande utilidade na análise e compreensão da dinâmica erosiva, dos seus fatores controladores e dos limites críticos para sua gênese e desenvolvimento.

\subsection{O Conceito de Limite Crítico e o Problema da Escala}

As situações de desequilíbrio dos sistemas são geradas quando as variáveis de força e/ou resistência são alteradas (RITTER et al., 1995). Se variações nos fatores controladores demandam uma resposta do sistema, há um período de reajuste, denominado de relaxation time (AHNERT, 1996), no qual processo e forma estão fora de equilíbrio. Portanto, se as condições de steady state de um sistema forem interrompidas por um distúrbio no fluxo de energia ou na resistência, o sistema sofrerá novos ajustes, tendo em vista o novo steady state a ser alcançado (HOWARD, 1965; CHORLEY, 1971).

O limite crítico $^{1}$ (threshold) separa diferentes estados de um sistema, marcando algum tipo de transição no comportamento, operação ou organização deste (HOWARD, 1965; CAMPBELL e HONSAKER, 1982; CROZIER, 1999; HUGGET, 2003). Portanto, quando o limite crítico é transposto, o sistema passa de uma situação de equilíbrio (steady state) para uma condição de desequilíbrio.

O steady state dos sistemas pode ser interrompido tanto por alterações nos processos como por modificações nas formas. O resultado do primeiro tipo de alteração é o estabelecimento de novas formas para alcançar um novo equilíbrio. No segundo caso, ocorrem alterações nos processos, modificando a qualidade dos inputs fornecidos ao sistema morfológico (CHRISTOFOLETTI, 1979). Assim, os processos geomorfológicos ocorrem somente após um limiar ser ultrapassado (WOLMAN e MILLER, 1960; HUGGET, 2003).

Para SCHUMM $(1973 ; 1979)$ a resposta do sistema a uma influência externa sucede-se após a transposição de um limite crítico extrínseco. Apesar de o limite crítico existir dentro do

\footnotetext{
1 Este trabalho utiliza os termos "limiar", "limite crítico" ou "condição crítica" como sinônimos que correspondem aos termos "threshold" ou "threshold condition" em língua inglesa.
} 
sistema, este não será atingido sem a influência de uma variável externa, e mesmo que as variáveis externas permaneçam relativamente constantes, o limite crítico pode ser excedido, à medida que uma mudança progressiva no sistema pode torná-lo instável.

CAMPBELL e HONSAKER (1982) tornam o conceito mais complexo ao descreverem os processos que eles denominam de subthresholds, os quais podem ser denominados alternativamente como a resiliência das formas de relevo. Os autores descrevem que os processos subthresholds podem produzir uma quantia de mudanças que são pequenas em certa escala, mas quando o limiar (threshold) do processo é excedido, a taxa de mudança repentinamente torna-se maior. Surge então uma questão: quando uma mudança é suficiente para habilitar-nos a discernir entre essas condições?

CAMPBELL e HONSAKER (1982) ressaltam a importância dessa questão, uma vez que ela requer a habilidade de definir rigorosamente a restrição de escalas espacial e temporal nas quais o sistema opera. Eles apontam que é evidente que diferentes paisagens possuem diferentes graus de resistência a mudanças e isso é expresso em termos de sua capacidade de absorver a energia aplicada externamente ou sofrer ajustes internos sem uma mudança visível. No entanto, a percepção destas mudanças na forma e suas variações são observadas no contexto da escala operacional, tanto espacial como temporal, na qual a paisagem é visualizada. Em efeito, a magnitude dos limiares e dos intervalos associados às respostas aumentam de acordo com a escala espacial da unidade de paisagem da mesma maneira que os conceitos de constante (steady), gradual e cíclico requerem uma perspectiva temporal (CAMPBELL e HONSAKER, 1982).

Neste sentido, WOLMAN e MILLER (1960) propõem que a eficácia de um mecanismo motor de um processo geomorfológico em moldar uma forma de relevo específica envolve a frequência de ocorrência do mecanismo (evento causal), bem como a magnitude individual do mesmo. Tendo em vista esta relação entre magnitude e frequência e entre as escalas espacial e temporal, CAMPBELL e HONSAKER (1982) sugeriram algumas relações possíveis entre os elementos do relevo e os seus eventos causais (Tabela 1). 


\begin{tabular}{lcl}
\hline \multicolumn{2}{c}{ Tabela 1: Relações possíveis entre elementos e eventos causais em diferentes escalas temporais e } \\
espaciais & Evento causal \\
\hline Elemento & Tamanho (metros) ou tempo (anos) & rajada d'água \\
\hline grão & $10^{-6}$ & sistema de tempestades \\
agregado & $10^{-3}$ & ciclo sazonal \\
segmento de encosta & $10^{0}$ & mudança climática \\
encosta & $10^{3}$ & placas tectônicas \\
cadeia de montanhas & $10^{6}$ &
\end{tabular}

Modificada de: CAMPBELL e HONSAKER (1982)

Conforme visto, a estabilidade ou a instabilidade de um sistema geomorfológico só podem ser efetivamente analisadas a partir da definição clara das escalas temporais e espaciais de análise, dependendo, portanto, da magnitude e frequência dos eventos causais dos processos que atuam na modificação das formas do relevo. A escala, por conseguinte, reflete na distinção entre causa e efeito entre as variáveis geomorfológicas, determinando a compreensão destas variáveis como dependentes ou independentes (SCHUMM e LICHTY, 1965; CRUZ, 1985).

\subsection{Identificação dos Limites Críticos: A Abordagem Declividade - Área de Contribuição (SA)}

A partir do conceito de limites críticos (thresholds), MONTGOMERY e DIETRICH $(1988 ; 1989 ; 1994)$ e DIETRICH et al. $(1992 ; 1993)$ consolidaram a abordagem DeclividadeÁrea de Contribuição (Slope-Area approach ou abordagem SA). Esta abordagem trata de limiares (limites críticos) geomorfológicos ou erosivos relacionados à topografia, tema cujo um dos pioneiros foi HORTON (1945). A proposta de HORTON (1945), utilizada por RUHE (1975) na definição de limiares para incisão de sulcos (rills) nas encostas, sugere a existência de um cinturão não-erosivo na encosta, ou seja, uma superfície cuja distância em relação ao topo e cuja declividade não são suficientes para as forças erosivas superarem a resistência do solo. HORTON (1945) denominou essa distância entre o divisor de águas e o ponto onde as forças erosivas tornam-se iguais às forças de resistência de distância crítica ou comprimento crítico (Figura 8). 


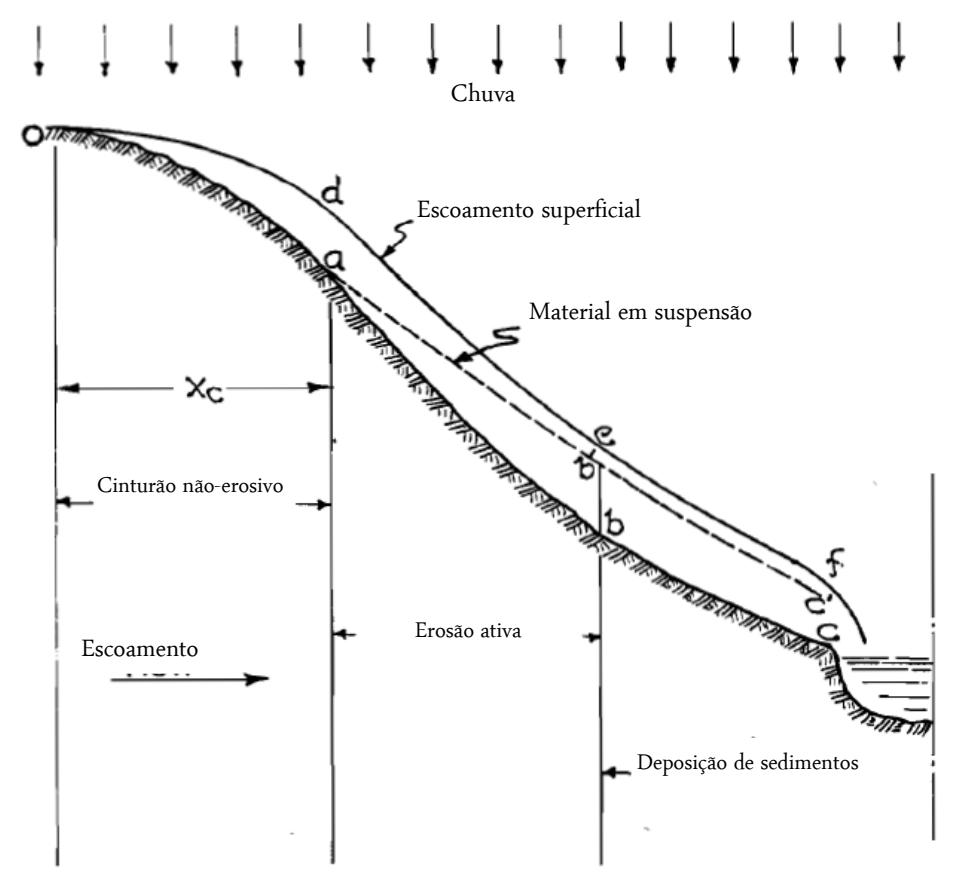

Figura 8: Perfil de encosta ilustrando os processos de erosão do solo conforme a descrição de HORTON (1945). A linha oabc representa o perfil da superfície do solo. A linha odef representa a superfície do escoamento superficial em lençol a partir de uma chuva intensa, com a profundidade do fluxo aumentando a jusante de $o$ para $f$. A linha $a b$ 'c' representa o material carreado pela água. Na região oa não ocorre erosão $\left(x_{c}\right.$ ou cinturão nãoerosivo), pois neste local a energia do escoamento não é suficiente para superar a resistência inicial da superfície do solo à erosão, até mesmo durante chuvas intensas. Modificada de: HORTON (1945).

Para MONTGOMERY e DIETRICH (1989; 1994) e DIETRICH et al. (1992) a abordagem dos limiares geomorfológicos relacionados à erosão a partir da relação entre área de contribuição e declividade, inspirada na hipótese de HORTON (1945), permite a elaboração de hipóteses acerca do comportamento hidrológico e erosivo das paisagens. Objetivando prever os locais propensos à formação de canais, a metodologia consolidada por eles consiste no estabelecimento da relação entre a área de contribuição da cabeceira um canal e a declividade local do vale a montante da mesma cabeceira.

MONTGOMERY e DIETRICH (1988) ressaltam que quanto mais próximos os canais estão dos divisores de águas, maior será o número de canais que vai ocupar uma área unitária e, consequentemente, mais dissecada será a paisagem. Para os autores, portanto, um componente-chave do crescimento da rede de canais e das teorias de evolução da paisagem, assim como de modelos de escoamento em bacias, é a predição de onde os canais se iniciam. 
Neste sentido, MONTGOMERY e DIETRICH (1994) afirmam que tanto a dimensão dos canais (caminhos de transporte de sedimentos dentro de margens bem definidas) como dos vales nos quais estes incidem (áreas topograficamente convergentes) refletem e interação entre processos erosivos, a resistência da superfície do solo a esses processos e os processos que atuam no preenchimento de incisões incipientes.

Os estudos em que a metodologia se baseia mostraram que a área de contribuição a montante de um canal diminui com o aumento do gradiente (declividade) local do seu vale, permitindo prever uma relação entre a área de contribuição e a declividade para a formação de canais em paisagens úmidas (MONTGOMERY e DIETRICH, 1988) (Figura 9). MONTGOMERY e DIETRICH (1989) assinalam que alguns elementos da paisagem ultrapassam o limiar, porém não constituem canais, explicando que isso indica que o limiar é difuso, ou seja, esses locais são suscetíveis, mas não chegaram a desenvolver canais. Ressaltase que DIETRICH et al. $(1992 ; 1993)$ analisaram a relação entre declividade e área de contribuição para outras posições das encostas, incluindo porções convexas, planares e côncavas, concluindo que nestes locais a área de contribuição não tem relação com a declividade local.

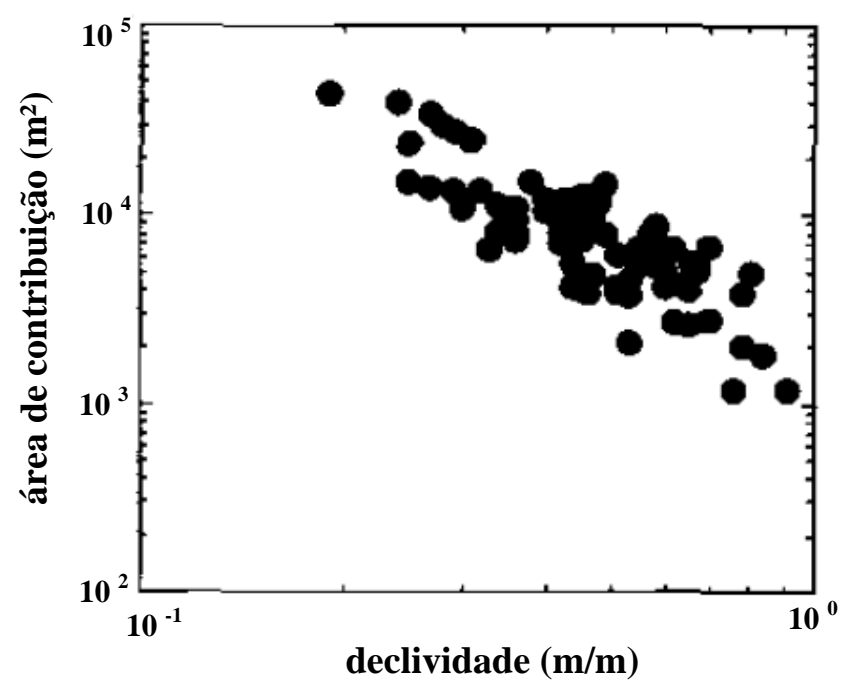

Figura 9: Relação entre área de contribuição $\left(\mathrm{m}^{2}\right.$; vertical) e declividade local $(\mathrm{m} / \mathrm{m}$; horizontal) em cabeceiras de canais do Tenessee Valley, Califórnia (Estados Unidos). Nestas áreas é evidente a relação inversamente proporcional entre área de contribuição e declividade nas cabeceiras de canais. Modificada de MONTGOMERY e DIETRICH (1994). 
MONTGOMERY e DIETRICH (1994), porém, ao avaliarem as bases físicas para o desenvolvimento de canais, demonstraram que a formação de canais por processos relacionados ao escoamento subsuperficial com a saturação do solo (seepage erosion), por exemplo, baseia-se numa correlação positiva entre área de contribuição e declividade, que define os locais pode ocorrer a saturação do solo

A abordagem SA possibilita, por conseguinte, definir os limiares entre a predominância de processos difusos na paisagem e a iniciação de canais, de modo que a relação entre área de contribuição e declividade fornece um quadro-conceitual para investigar a resposta da paisagem a mudanças (MONTGOMERY e DIETRICH, 1994). Neste sentido, a área de contribuição pode ser considerada como uma substituta para o volume de escoamento superficial e subsuperficial, enquanto a declividade, relacionada à velocidade do escoamento, pode ser considerada como a variável independente da relação, devido ao longo tempo de resposta e a erosão do substrato requerida para alterar significativamente o perfil ao longo dos vales (MONTGOMERY e DIETRICH, 1994). Tais autores propõem que esta constatação sugere que o tamanho da área de contribuição responde às mudanças climáticas e à alteração na dinâmica dos processos por meio da migração da cabeceira do canal ao longo do eixo do vale.

A partir dessas hipóteses, MONTGOMERY e DIETRICH (1988) sugerem que já que o runoff é incrementado com o aumento da área de contribuição em uma dada declividade, o tamanho da área de contribuição requerido para a gênese de um canal deve aumentar com o aumento da aridez, de modo que se obtenha a mesma combinação crítica de runoff e declividade na cabeceira do canal. Deste modo, os autores refletem que nas áreas de contribuição de regiões úmidas, as cabeceiras de canais vão recuar a jusante com o incremento da aridez, resultando em processos de agradação nas partes mais altas dos canais de primeira ordem. Similarmente, é esperado que as cabeceiras avancem a montante, nos depósitos coluviais dos vales, em períodos úmidos. 


\subsection{Questões Metodológicas e a Abordagem Declividade - Área de Contribuição no Estudo da Erosão Linear}

Apesar de os trabalhos de MONTGOMERY e DIETRICH $(1988 ; 1989 ; 1994)$ e de DIETRICH et al. $(1992$; 1993) terem consolidado a abordagem SA a partir de estudos generalizados em diversas áreas e do estabelecimento das principais reflexões teóricas sobre o assunto, foram PATTON e SCHUMM (1975) que primeiramente utilizaram essa metodologia. A partir da relação entre declividade e área de contribuição, e tendo em vista o conceito de threshold de SCHUMM (1973), estes autores estudaram os limites críticos para a ocorrência de discontinuous gullies no Noroeste do Colorado.

Desde o trabalho de PATTON e SCHUMM (1975) diversas pesquisas têm se apropriado da relação entre declividade e área de contribuição para explicar processos de encosta relacionados à formação de canais. A leitura destes estudos, em parte sintetizados na Tabela 2, permite verificar que eles apresentam grande variação quanto aos procedimentos adotados, seja na identificação e mapeamento das feições, no cálculo da declividade e da área de contribuição ou no próprio estabelecimento do limite crítico entre a ocorrência e a não ocorrência do processo em análise. Esta variação, em geral, tem dificultado comparações entre os resultados e a formulação de leis gerais da relação entre declividade e área de contribuição.

A questão do método de observação e do mapeamento das feições ou canais parece ser a mais consensual. Apesar das variações quanto aos procedimentos de coleta dos dados, que vão do levantamento de campo à fotointerpretação, esta diversidade não aparenta afetar significativamente os resultados. Sobre a escolha do método de identificação das feições, VANDAELE et al. (1996) sublinham que apesar de os levantamentos de campo serem mais precisos, o uso de fotografias aéreas pode ser vantajoso para cobrir um longo período de observação. 


\begin{tabular}{|c|c|c|c|c|c|}
\hline Pesquisa & Incisão por & $\begin{array}{l}\text { Método de } \\
\text { observação }\end{array}$ & $\begin{array}{l}\text { Limite } \\
\text { crítico* }\end{array}$ & Cálculo de A & Cálculo de S \\
\hline $\begin{array}{l}\text { PATTON e } \\
\text { SCHUMM } \\
\quad(1975)\end{array}$ & $\begin{array}{c}\text { Gullying (discontinuous } \\
\text { gullies) }\end{array}$ & $\begin{array}{l}\text { Fotografias } \\
\text { aéreas }\end{array}$ & $\begin{array}{l}\text { Linha no } \\
\text { limite } \\
\text { inferior** }\end{array}$ & $\begin{array}{c}\text { Cartas } \\
\text { topográficas }\end{array}$ & $\begin{array}{c}\text { Cartas } \\
\text { topográficas }\end{array}$ \\
\hline $\begin{array}{l}\text { MONTGOMER } \\
\text { Y e DIETRICH } \\
(1988)\end{array}$ & $\begin{array}{l}\text { Landsliding, seepage } \\
\text { erosion e overland flow } \\
\text { erosion }\end{array}$ & $\begin{array}{l}\text { Levantamento } \\
\text { de campo }\end{array}$ & - & $\begin{array}{c}\text { Cartas } \\
\text { topográficas }\end{array}$ & $\begin{array}{c}\text { Levantamento } \\
\text { de campo }\end{array}$ \\
\hline $\begin{array}{l}\text { DIETRICH et al. } \\
(1993)\end{array}$ & $\begin{array}{c}\text { Shallow landsliding e } \\
\text { saturated overland flow } \\
\text { erosion }\end{array}$ & $\begin{array}{c}\text { Levantamento } \\
\text { de campo }\end{array}$ & - & $\begin{array}{l}\text { Modelo Digital } \\
\text { de Terreno }\end{array}$ & $\begin{array}{c}\text { Modelo Digital } \\
\text { de Terreno }\end{array}$ \\
\hline $\begin{array}{l}\text { VANDAELE et } \\
\text { al. (1996) }\end{array}$ & $\begin{array}{l}\text { Overland flow (ephemeral } \\
\text { gullies) }\end{array}$ & $\begin{array}{l}\text { Fotografias } \\
\text { aéreas }\end{array}$ & $\begin{array}{l}\text { Linha } \\
\text { paralela }\end{array}$ & $\begin{array}{l}\text { Modelo Digital } \\
\text { de Terreno }\end{array}$ & $\begin{array}{l}\text { Modelo Digital } \\
\text { de Terreno }\end{array}$ \\
\hline $\begin{array}{c}\text { OOSTWOUD } \\
\text { WIJDENES et al. } \\
\text { (1999) }\end{array}$ & Overland flow (gullying) & $\begin{array}{c}\text { Levantamento } \\
\text { de campo }\end{array}$ & - & $\begin{array}{l}\text { Levantamento } \\
\text { de campo }\end{array}$ & $\begin{array}{c}\text { Levantamento } \\
\text { de campo }\end{array}$ \\
\hline $\begin{array}{l}\text { VANDEKERCK } \\
\text { HOVE et al. } \\
(2000)\end{array}$ & $\begin{array}{c}\text { Overland flow, piping, } \\
\text { tension cracks, etc. (bank } \\
\text { gullies) }\end{array}$ & $\begin{array}{l}\text { Fotografias } \\
\text { aéreas }\end{array}$ & - & $\begin{array}{l}\text { Levantamento } \\
\text { de campo }\end{array}$ & $\begin{array}{c}\text { Levantamento } \\
\text { de campo }\end{array}$ \\
\hline VIEIRA (2002) & Escoamento superficial & $\begin{array}{c}\text { Levantamento } \\
\text { de campo }\end{array}$ & $\begin{array}{l}\text { Linha } \\
\text { ajustada }\end{array}$ & $\begin{array}{l}\text { Cartas } \\
\text { topográficas }\end{array}$ & $\begin{array}{c}\text { Levantamento } \\
\text { de campo }\end{array}$ \\
\hline $\begin{array}{c}\text { COELHO } \\
\text { NETTO (2003) }\end{array}$ & $\begin{array}{c}\text { Fluxos d'água } \\
\text { subterrâneos (voçorocas) }\end{array}$ & - & - & - & - \\
\hline $\begin{array}{l}\text { MORGAN e } \\
\text { MNGOMEZULU } \\
\text { (2003) }\end{array}$ & $\begin{array}{l}\text { Hortonian overland flow } \\
\text { e subsurface processes } \\
\text { (seepage) (valley-side } \\
\text { gullies) }\end{array}$ & $\begin{array}{l}\text { Fotografias } \\
\text { aéreas }\end{array}$ & $\begin{array}{c}\text { Análise } \\
\text { discrimina } \\
\text { nte }\end{array}$ & $\begin{array}{c}\text { Cartas } \\
\text { topográficas }\end{array}$ & $\begin{array}{c}\text { Cartas } \\
\text { topográficas }\end{array}$ \\
\hline $\begin{array}{l}\text { VANWALLEGU } \\
\text { EM et al. (2005) }\end{array}$ & $\begin{array}{l}\text { Hortonian e saturated } \\
\text { overland flow e seepage } \\
\text { (shallow ephemeral } \\
\text { gullies e deep gullies) }\end{array}$ & $\begin{array}{c}\text { Levantamento } \\
\text { de campo }\end{array}$ & $\begin{array}{c}\text { Linha } \\
\text { paralela }\end{array}$ & $\begin{array}{l}\text { Levantamento } \\
\text { de campo }\end{array}$ & $\begin{array}{c}\text { Levantamento } \\
\text { de campo }\end{array}$ \\
\hline $\begin{array}{l}\text { VERACHTERT } \\
\text { et al. }(2010)\end{array}$ & Piping & $\begin{array}{c}\text { Levantamento } \\
\text { de campo }\end{array}$ & $\begin{array}{l}\text { Linha } \\
\text { paralela }\end{array}$ & $\begin{array}{l}\text { Modelo Digital } \\
\text { de Terreno }\end{array}$ & $\begin{array}{l}\text { Levantamento } \\
\text { de campo }\end{array}$ \\
\hline ARAUJO (2011) & $\begin{array}{c}\text { Sulcos, ravinas e } \\
\text { voçorocas }\end{array}$ & $\begin{array}{l}\text { Levantamento } \\
\text { de campo }+ \\
\text { fotografias } \\
\text { aéreas }\end{array}$ & $\begin{array}{l}\text { Linha } \\
\text { ajustada }\end{array}$ & $\begin{array}{l}\text { Modelo Digital } \\
\text { de Terreno }\end{array}$ & $\begin{array}{l}\text { Modelo Digital } \\
\text { de Terreno }\end{array}$ \\
\hline \multicolumn{6}{|c|}{$\begin{array}{l}\text { * Linha no limite inferior: método no qual se traça uma linha abaixo dos dados plotados; Linha paralela: método no } \\
\text { qual se traça uma linha paralela à linha de regressão dos dados de áreas com feições no limite inferior dos dados } \\
\text { plotados (relação S x A); Linha ajustada: não foi descrito o método de definição do limite, mas aparentemente foi } \\
\text { traçada uma linha para a melhor separação entre locais com e sem incisão; Análise discriminante: método no qual se } \\
\text { realiza uma análise estatística discriminante para os dados de áreas com e sem feições. } \\
\text { ** PATTON e SCHUMM (1975) utilizaram também a análise discriminante, mas para determinar a validade } \\
\text { estatística da distinção entre bacias com e sem feições e não para determinar limites críticos. }\end{array}$} \\
\hline
\end{tabular}


Por outro lado, os procedimentos de cálculo da área de contribuição, em menor grau, e do cálculo da declividade, em maior grau, são um dos grandes responsáveis pelo problema da comparação dos resultados. As diferenças na estimativa da área de contribuição são normalmente menos significativas, resultantes, principalmente, do método de levantamento dos dados, como foi indicado na Tabela 2. De outro modo, a heterogeneidade no cálculo da declividade advém muito pouco da metodologia de levantamento dos dados, mas, nomeadamente do "trecho" de declividade considerado. A maior parte dos trabalhos citados na Tabela 2, por exemplo, utilizou a declividade local logo acima da cabeceira do canal estudado, porém, ocorrendo variações: PATTON e SCHUMM (1975) consideraram a declividade entre as duas curvas de nível mais próximas da cabeceira do canal a partir de cartas topográficas na escala 1:50.000; DIETRICH et al. (1993) utilizaram unidades elementares definidas pelo Modelo Digital de Terreno TOPOG; enquanto outros autores consideraram uma distância ( 2 metros, 3 metros, 10 metros etc.) a partir da cabeceira do canal. Já trabalhos como de MORGAN e MNGOMEZULU (2003) empregaram a declividade no eixo da concavidade (topographic swale) entre a cabeceira do canal e o divisor de águas e, outros trabalhos citados por MONTGOMERY e DIETRICH (1994), assim como ARAUJO (2011), fizeram a análise com a declividade média da área de contribuição do canal.

Apesar das divergências nas mensurações da declividade, existe pouca discussão teórica a respeito de qual seria o método mais adequado. A exceção é o trabalho de MONTGOMERY e DIETRICH (1988), no qual os autores afirmam que a medição da declividade apenas logo a montante do canal, e não a declividade média da área de contribuição, é um critério importante, pois os processos erosivos que controlam as cabeceiras dos canais seriam muito influenciados pela declividade local.

A partir da plotagem dos dados de declividade e área de contribuição, PATTON e SCHUMM (1975) propuseram que uma linha traçada no limite inferior destes dados representaria o limiar da ocorrência dos processos de incisão das gullies do Noroeste do Colorado. Esta análise foi posteriormente modificada por trabalhos como o de VANDAELE et al. (1996) e VANWALLEGUEM et al. (2005), de modo que estes autores sugeriram que a linha traçada como o limite crítico deveria ser paralela à linha da regressão dos dados plotados (Figura 10a). 
MORGAN e MNGOMEZULU (2003) criticam os trabalhos que utilizam este tipo de metodologia para a definição de limites críticos, sob a justificativa de que estas pesquisas apenas consideram as bacias com a ocorrência de processos de incisão (por exemplo, voçorocas), ignorando a possibilidade de bacias sem a ocorrência desses processos terem excedido os limites críticos. Portanto, a proposta dos autores é o levantamento da relação entre a declividade e área de contribuição em canais com a ocorrência das gullies e em canais sem gullies, permitindo sua comparação. A definição dos limites críticos nesse estudo foi realizada a partir da análise discriminante entre os dados (Figura 10b), de modo que os autores concluíram que este tipo de análise foi capaz de distinguir as bacias com e sem ocorrência de gullies razoavelmente bem, com apenas alguns exemplos sendo classificados erroneamente. Os autores demonstraram ainda que a função discriminante e a reta de regressão melhor ajustadas às bacias com voçorocas não são paralelas, concluindo que a demarcação de uma reta paralela à regressão dos dados de bacias com gullies abaixo dos dados é um fraco indicador do limite crítico para a ocorrência das gullies.

Como exemplo de trabalho onde a abordagem não teve resultados significativos, podese citar COELHO NETTO (2003) que relata que o modelo SA não é aplicável diretamente às cabeceiras do vale do Rio Bananal, tanto pela alta dispersão dos valores como pela ocorrência de canais (voçorocas) muito próximos ao divisor de águas, ou seja, com área de contribuição quase nula, sem, no entanto, detalhar os procedimentos de tratamento dos dados. A partir disso, a autora concluiu que apenas os elementos físicos não explicariam a formação destes vales, demandando uma maior compreensão dos processos químicos na esculturação destas encostas.

MORGAN e MNGOMEZULU (2003) ressaltam que as funções dos limites críticos variam de acordo com o sistema de cultivo estudado, ou seja, que os limiares variam de acordo com outros aspectos da paisagem, não se podendo determinar limiares universais, como também assinalam PATTON e SCHUMM (1975), SCHUMM (1979) e POESEN et al. (2003). Sobre isso, POESEN et al. (2003) destacam que o conceito de limite crítico permite a determinação na paisagem de onde as gullies podem se desenvolver, fornecendo uma base física para a previsão da deflagração destes processos. Eles lembram, porém, que diversos fatores atuam influenciando a posição das linhas de limite crítico, que vão desde as características do ambiente local até os métodos de pesquisa, incluindo os próprios mecanismos de formação das feições (escoamento superficial, erosão por excesso de poropressão, movimentos de massa, etc.). 

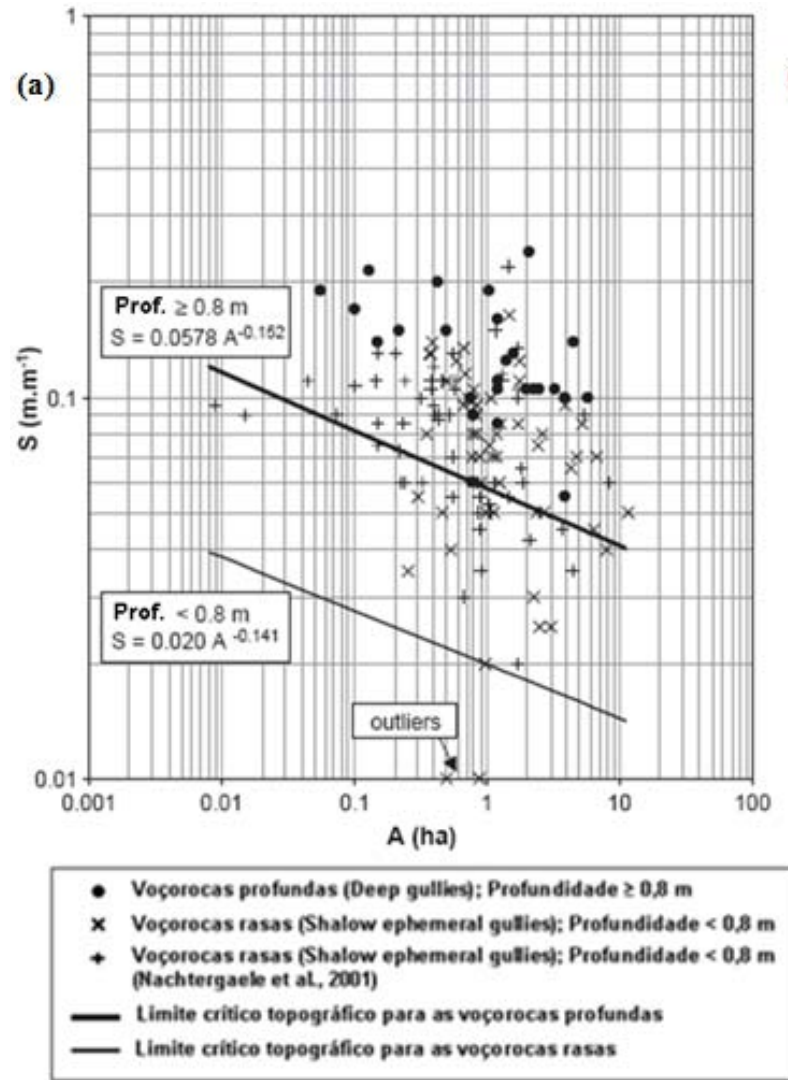

Figura 10: a) Relação entre área de contribuição (ha; horizontal) e declividade local (m/m; vertical) em deep gullies e shallow ephemeral gullies no Loess Belt belga. As retas representam os limites críticos para a incisão de deep gullies e de shallow ephemeral gullies, sendo que seu ângulo foi obtido a partir da análise de regressão dos dados de cada uma das tipologias. Modificada de VANWALLEGUEM et al. (2005). (b) Relação entre área de contribuição (ha; horizontal) e declividade local ( $\mathrm{m} / \mathrm{m}$; vertical) em Mtilane (Suazilândia). A reta, estabelecida a partir da análise estatística discriminante, representa o limite crítico entre a ocorrência e não ocorrência de gullies. Modificada de MORGAN e MNGOMEZULU (2003).

Para POESEN et al. (2003) e SIDORCHUK (2006) a formação de gullies é claramente um fenômeno associado à limites críticos. Segundo os primeiros, as funções de limite crítico para a deflagração desses processos podem ser representadas pela Equação 1:

$$
S=a A^{b}
$$

onde: $S$ é a declividade da superfície; $A$ é a área de contribuição da cabeceira do canal; e $a$ e $b$ são coeficientes que dependem das características do ambiente. POESEN et al. (2003) 
observam ainda que apesar da relação SA ser extensivamente estudada para a formação de gullies, poucas relações entre declividade e área de contribuição têm sido delineadas para a localização de onde estas feições terminam.

Com a compreensão dos processos de erosão linear como resultantes de uma situação de desequilíbrio em um sistema geomorfológico, da complexidade da dinâmica destes processos e partindo do conceito de limites críticos para a formação de canais por processos de erosão linear, adquire-se uma base teórica suficiente para a compreensão da erosão linear como um processo de busca por um novo ajuste (equilíbrio dinâmico), cujo limite crítico da situação anterior, expresso pela relação entre declividade e área de contribuição, não mais se sustenta, sendo necessária uma nova relação, que é alcançada com a estabilização das feições erosivas lineares. 


\section{PROCEDIMENTOS METODOLÓGICOS E TÉCNICO-OPERACIONAIS}

Para avaliar os limites críticos topográficos para o desenvolvimento das formas resultantes de processos vinculados à erosão linear, foram definidos os procedimentos metodológicos e técnico-operacionais da pesquisa, que podem ser divididos em quatro etapas: seleção da área de estudo (3.1); identificação e caracterização das feições erosivas (3.2); mensuração da declividade e área de contribuição (3.3); e, definição dos limites críticos topográficos (3.4).

\subsection{Seleção da Área de Estudo}

A pesquisa foi conduzida em uma área composta por diversas cabeceiras de drenagem na porção central do município de Piratininga, região de Bauru (SP), especificamente nas bacias da alta Água da Faca e alto Rio Alambari (Mapa 1).

No contexto geral, optou-se pelo estudo do Planalto Ocidental Paulista e em um segundo momento pela região de Bauru (SP), visto este ser um compartimento geomorfológico intensamente afetado pela erosão linear, conforme os estudos de DAEE/IPT (1990) e OLIVEIRA e QUEIROZ NETO (1993). Em especial IPT (1994), na "Carta Geotécnica do Estado de São Paulo, escala 1:500.000”, classificou a região de Bauru (SP) como área de muita suscetibilidade a erosão por sulcos, ravinas e voçorocas. Além disso, as poucas apreciações brasileiras a respeito dos limites críticos topográficos restringem-se às feições erosivas em áreas de embasamento cristalino, destacando-se os estudos de VIEIRA (2002) e COELHO NETTO (2003) na região de Bananal (SP/RJ). A exceção é o estudo de ARAUJO (2011), que analisa os limiares topográficos para o desenvolvimento de sulcos, ravinas e voçorocas em São Pedro (SP), na morfoescultura denominada Depressão Periférica Paulista.

A partir desta seleção prévia, passou-se para a escolha das feições erosivas a serem efetivamente estudadas. Utilizaram-se como base os trabalhos de SALOMÃO (1994), STABILE (2009) e STABILE e VIEIRA (2009a; 2009b), principalmente o primeiro, que regionalizou parte da região de Bauru quanto à suscetibilidade à erosão relacionada aos aspectos pedológicos e hidrológicos. 


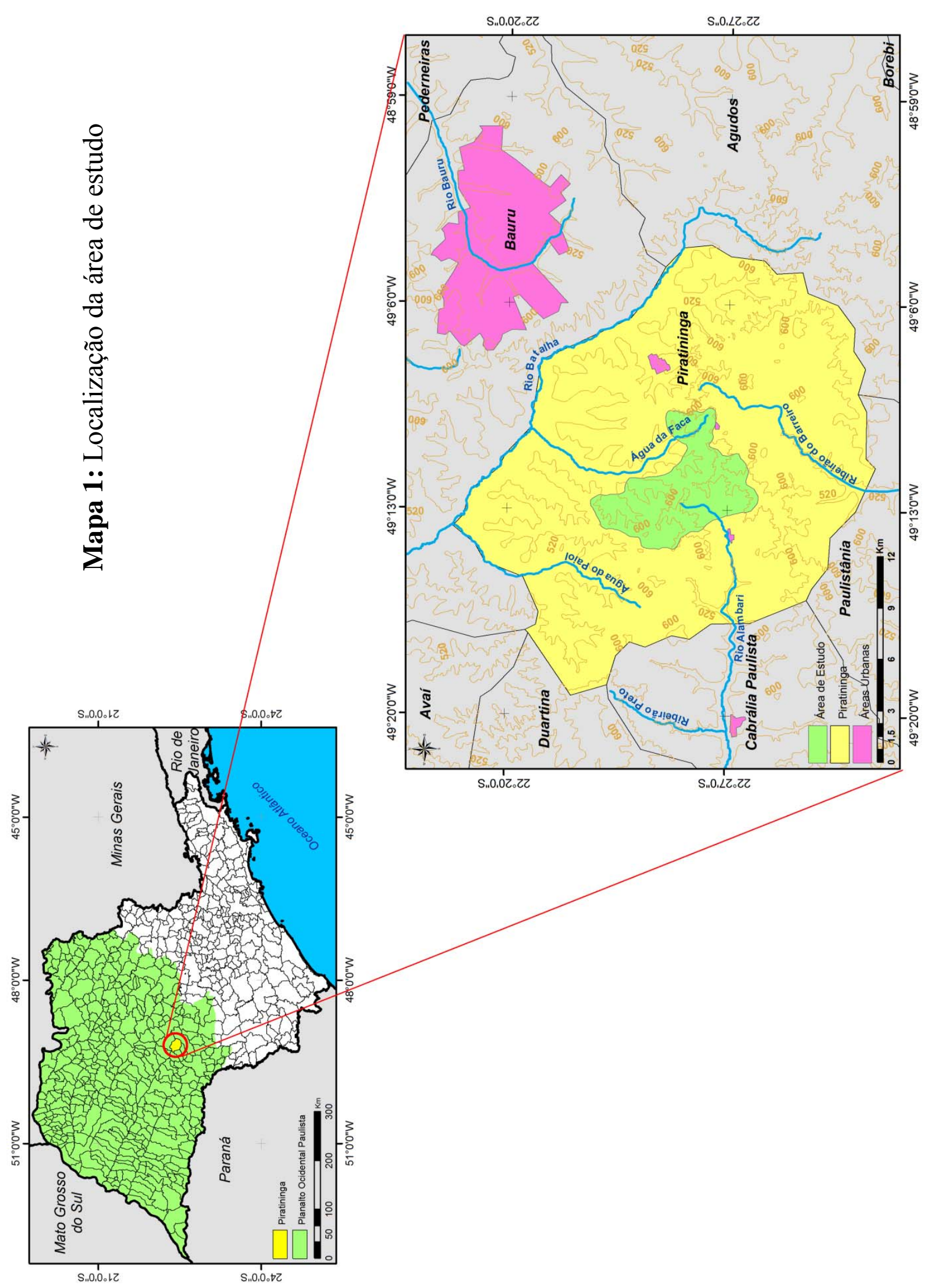


Com o uso do software Google Earth, que disponibiliza imagens do satélite Geoeye do ano de 2010 na região de Bauru, observou-se a distribuição das feições erosivas na região, buscando identificar também: a influência de elementos lineares antrópicos (estradas, cercas, carreadores, etc.) na concentração do escoamento e no desenvolvimento das feições erosivas, que poderiam dificultar a análise dos limites críticos com base em declividade e área de contribuição; a facilidade de acesso às cabeceiras das feições, considerando a posterior realização de trabalhos de campo; e as formas de uso do solo, tendo como preferência usos semelhantes de modo a não afetarem significativamente os resultados.

Contrariando as expectativas iniciais, verificou-se que boa parte das feições erosivas na área estudada por SALOMÃO (1994) não existem atualmente, tendo sido provavelmente enterradas, florestadas ou transformadas em açudes, principalmente devido às mudanças de uso do solo atuais (de pastagens para reflorestamentos). Além disso, outro conjunto de feições está associado à área periurbana de Bauru e a loteamentos rurais, que muito provavelmente teriam papel no escoamento superficial e no desenvolvimento das feições erosivas.

A presumível dificuldade na identificação das cabeceiras e até mesmo da execução posterior dos trabalhos de campo pela falta de acesso às propriedades, bem como a influencia de estruturas antrópicas no escoamento superficial, fez com que a maior parte da área mapeada por SALOMÃO (1994) fosse desconsiderada para continuidade da pesquisa.

Foram selecionadas da área anteriormente mapeada por SALOMÃO (1994) apenas algumas feições erosivas na alta bacia da Água da Faca. O restante das feições selecionadas situa-se mais a oeste, na alta bacia do Rio Alambari, onde as transformações de uso do solo ainda não são tão intensas, e as feições erosivas estão conservadas, permitindo a execução de todas as etapas da pesquisa.

\subsection{Identificação e Caracterização das Feições Erosivas}

A identificação das feições erosivas inicialmente foi realizada por meio do software Google Earth, que disponibiliza imagens do satélite Geoeye do ano de 2010. A partir dessa identificação, foram selecionadas algumas áreas para a realização de trabalhos de campo com o objetivo de definir as feições a serem estudadas. Ressalta-se que as feições analisadas aproximam-se mais do conceito de voçoroca, tanto devido às suas dimensões como à aparente complexidade dos processos envolvidos na sua esculturação. 
A realização dos trabalhos de campo também teve a função da marcação das coordenadas geográficas na cabeceira de cada uma das feições erosivas escolhidas com o uso de um GPS. Cabe destacar que nos trabalhos de campo algumas vezes observou-se a variação nas características ao longo das feições erosivas, de modo que em muitas delas foram marcados pontos de cabeceiras denominadas "de montante" e "de jusante". As primeiras normalmente constituem canais totalmente cobertos por vegetação (principalmente gramíneas) e com bordas suaves, enquanto os últimos representam uma ruptura abrupta na encosta a partir da cabeceira, tendo como característica principal as paredes íngremes (Figura 11). Nas feições mais ramificadas os pontos de GPS foram, em alguns casos, marcados em dois ou mais braços da feição erosiva.

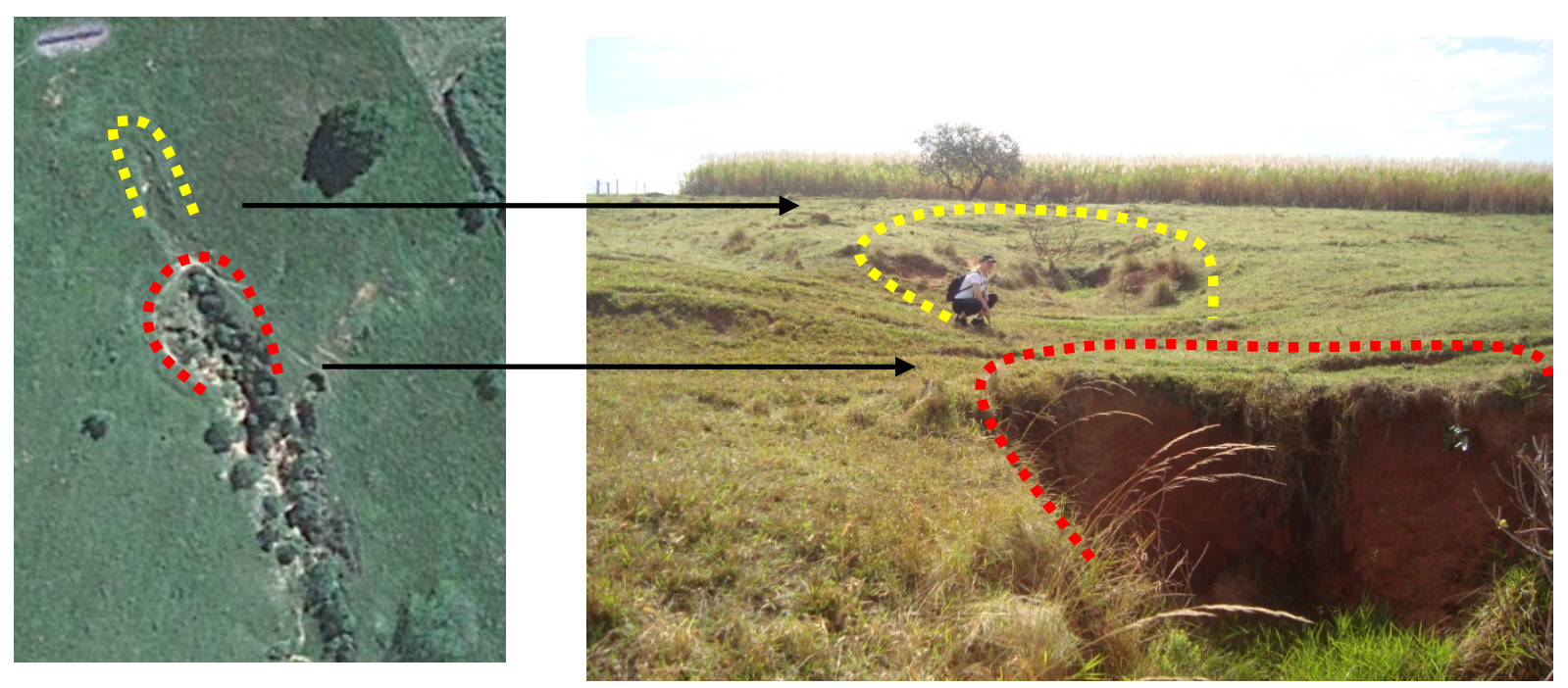

Figura 11: Demonstração da variação nas características ao longo das feições erosivas em uma das feições em estudo. As bordas amarelas circundam as cabeceiras denominadas "de montante", enquanto que as bordas vermelhas circundam as cabeceiras denominadas de "de jusante". Fonte: Google Earth, 2010

Além da marcação das coordenadas, os trabalhos de campo auxiliaram a caracterização das feições erosivas, com a descrição de seus principais atributos. Para a realização desta etapa foi elaborada uma ficha de campo (Anexo I), contendo diversas informações morfológicas da feição erosiva e características do seu entorno.

Aproveitando os pressupostos de SALOMÃO (1994) e ALMEIDA FILHO (2000), de que quase todas as feições erosivas na região de Bauru já existiam em 1972, e que essa data está próxima do máximo desenvolvimento dessas feições, decidiu-se identificar a cabeceira das feições erosivas estudadas em fotografias aéreas, a fim de se estabelecer a relação entre 
declividade e área de contribuição também nessa data. As fotografias aéreas utilizadas datam de março de 1972 e compõem o levantamento aerofotogramétrico do Instituto Brasileiro do Café (IBC), com escala aproximada de 1:25.000 ${ }^{2}$.

Primeiramente as fotografias aéreas foram digitalizadas e posteriormente georreferenciadas por meio do programa $\operatorname{ArcMap}^{T M} 9.2$ (ESRI®). A partir daí criou-se um layer de pontos que assinala a cabeceira das feições erosivas. Além das feições analisadas em campo, decidiu-se incluir outras feições erosivas próximas e com características semelhantes, assim como feições menores, mais associadas ao conceito de ravina ou até mesmo sulcos mais profundos. Além disso, algumas feições mapeadas em campo foram excluídas desta análise, visto ter sido verificada a influência de estruturas antrópicas como caminhos, ferrovias etc. As fotografias aéreas de 1972 permitiram ainda a anotação dos pontos de início de parte das feições erosivas, ou seja, foi criado outro layer contendo o ponto de jusante das feições, sobretudo das voçorocas (Figura 12).

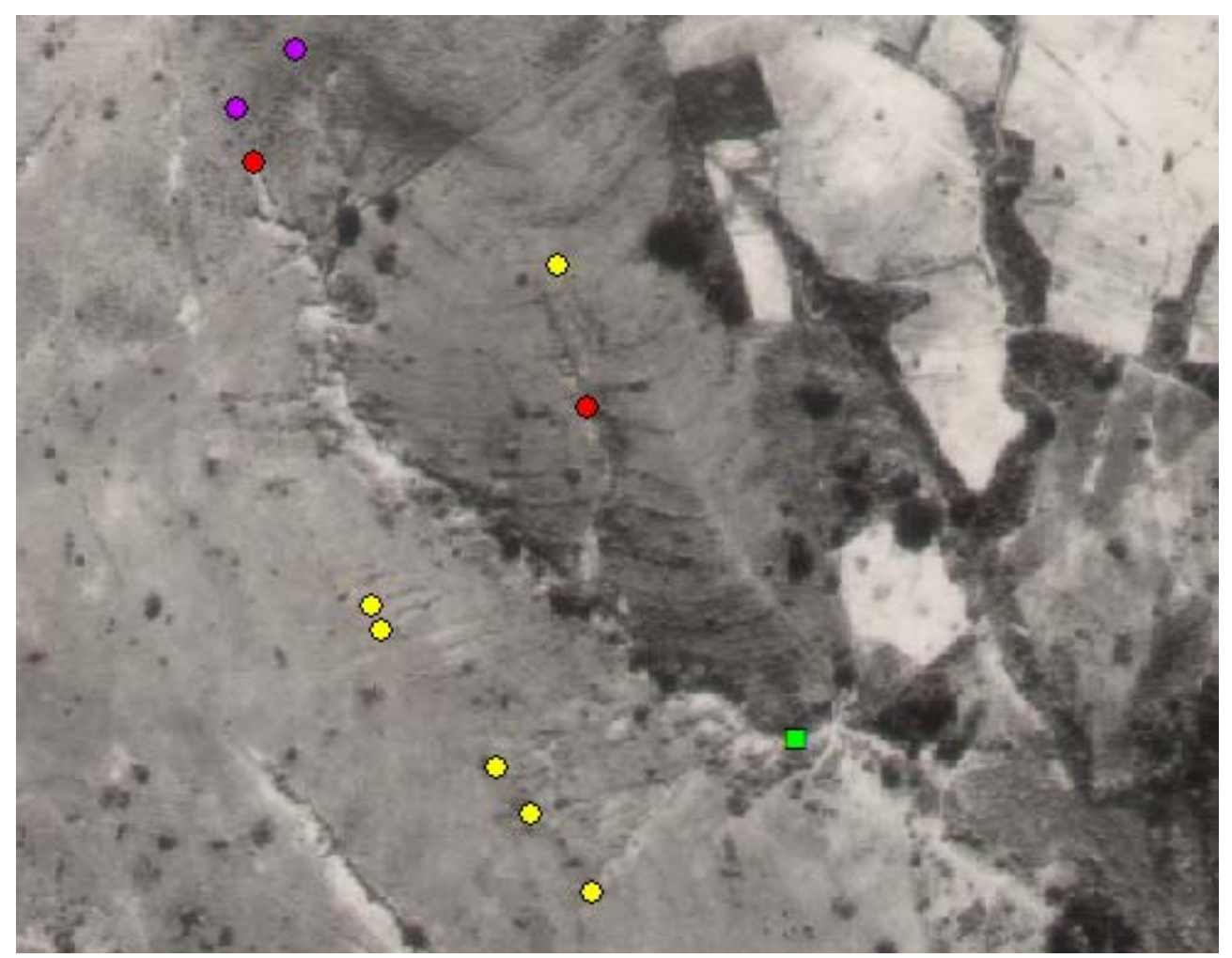

Figura 12: Exemplo de uma cabeceira de drenagem estudada. Ampliação da fotografia aérea de 1972 (escala 1:5.000). O quadrado verde representa o ponto de início da feição; os círculos amarelos representam as cabeceiras dos sulcos e ravinas; os círculos vermelhos representam as cabeceiras da voçoroca e seu ramo principal; enquanto que os círculos roxos as cabeceiras do corpo principal da voçoroca e de um de seus ramos a partir de coordenadas do GPS no trabalho de campo. Fonte da fotografia aérea: Instituto Brasileiro do Café (1972).

\footnotetext{
${ }^{2}$ As fotografias aéreas foram cedidas pelo acervo do Instituto de Pesquisas Tecnológicas do Estado de São Paulo (IPT).
} 
No término desta etapa, os principais produtos finais foram os layers de pontos contendo: 73 cabeceiras de 42 feições atuais (incluindo as rupturas já descritas no interior das feições); 74 cabeceiras de voçorocas, ravinas e sulcos mais profundos com base em fotografias aéreas do ano de 1972; e, 18 pontos de início ou jusante das voçorocas com base em fotografias aéreas do ano de 1972.

\subsection{Mensuração da Declividade e da Área de Contribuição}

A determinação da área de contribuição e da declividade a montante de cada uma das feições erosivas, assim como o subitem anterior, foi dividida em duas etapas: a primeira etapa consistiu na determinação das declividades e das áreas de contribuição das cabeceiras das feições erosivas atuais; e, a segunda etapa consistiu na mensuração das declividades e áreas de contribuição dos pontos mapeados nas fotografias aéreas de 1972.

Com a finalidade de comparar alguns dos métodos disponíveis na bibliografia para a mensuração da declividade, para as feições erosivas atuais foram realizadas medições em campo, assim como foram gerados dados de declividade por meio de um Modelo Digital de Terreno (MDT). Considerou-se o pressuposto de MONTGOMERY e DIETRICH (1988) de que os processos erosivos que controlam as cabeceiras dos canais seriam muito influenciados pela declividade local. Assim, em ambas as abordagens (em campo e por meio do MDT), a declividade foi mensurada apenas localmente junto à cabeceira da feição erosiva.

Para a determinação da declividade em campo foi utilizado um pantômetro. Esse instrumento consiste em uma estrutura formada por duas hastes verticais e duas hastes de interligação horizontais, além de dois níveis de bolha (um em cada haste vertical) e um transferidor (Figura 13).

A declividade é obtida pelo pantômetro a partir do posicionamento das duas hastes verticais no terreno, sendo que os níveis de bolha, os quais devem ser previamente ajustados em terreno plano, devem garantir que as duas hastes estejam exatamente a 90 graus de declividade no terreno. Após o posicionamento a leitura da declividade é realizada no transferidor (que deve estar posicionado a montante) com o auxilio de uma marca na haste horizontal superior (Figura 14). Desse modo é obtido um ângulo que corresponde à declividade do terreno entre as duas hastes verticais, que corresponde a uma distância de 1,5 metros no pantômetro utilizado neste trabalho. 


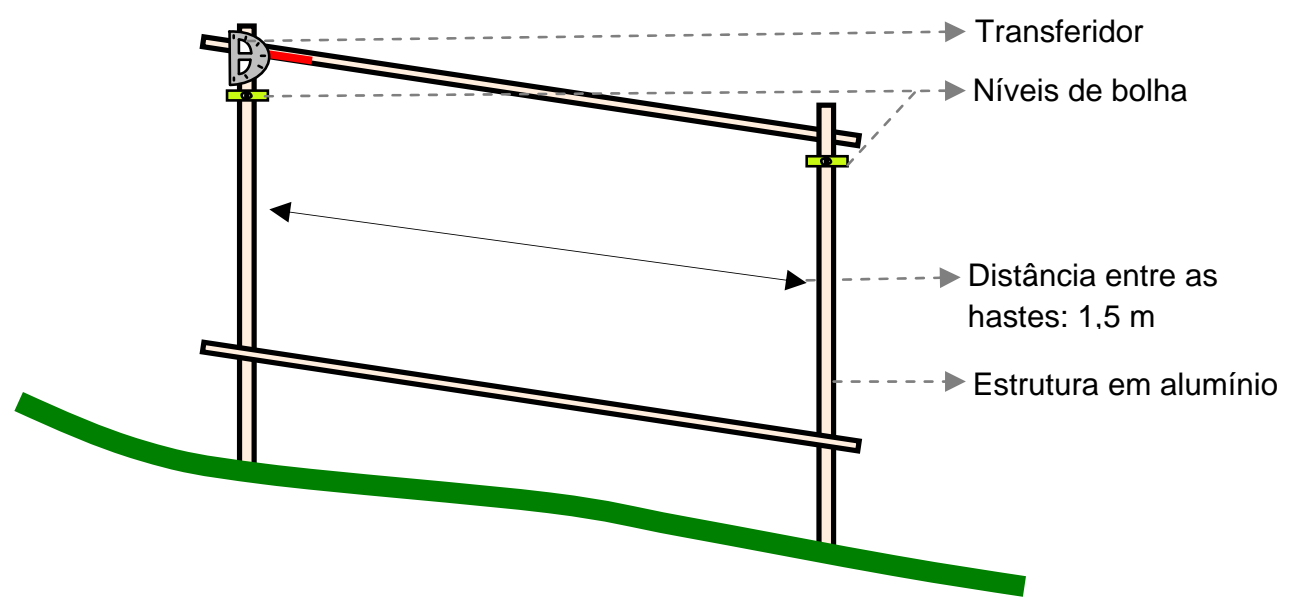

Figura 13: Esquema ilustrativo de um pantômetro.
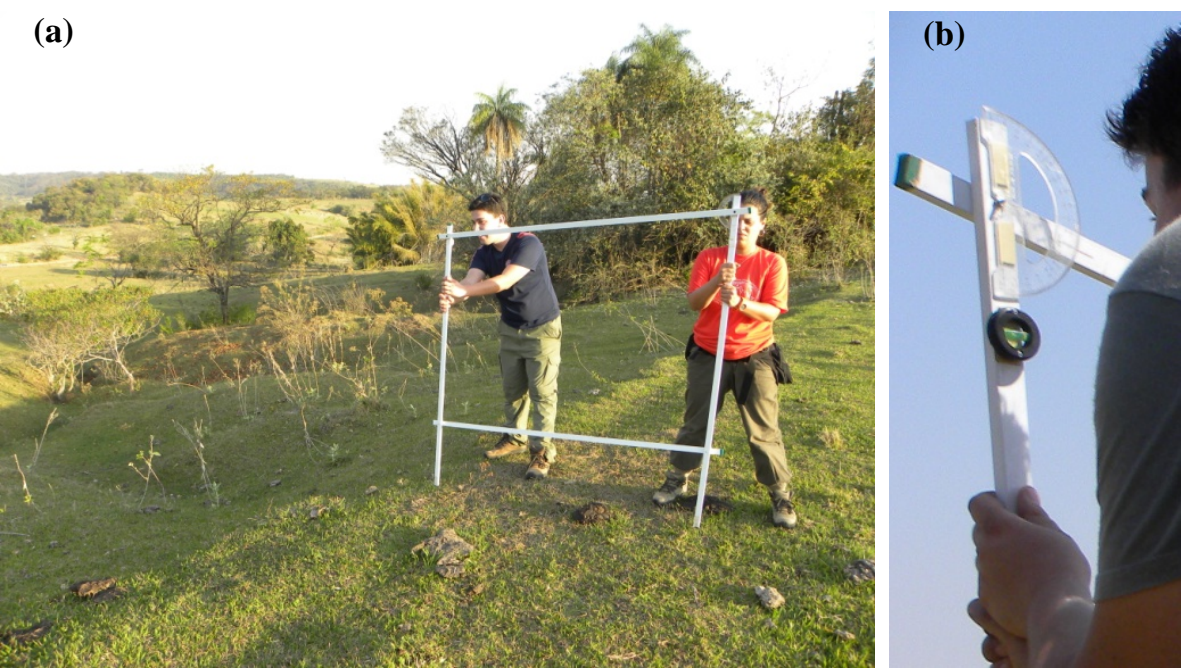

Figura 14: Exemplo da utilização do pantômetro na mensuração da declividade a montante da cabeceira de uma feição erosiva (a) e, detalhe da leitura do ângulo no transferidor e do nível de bolha (b). 
Em cada cabeceira foram realizadas quatro medidas logo a montante da cabeceira na linha de maior declive, correspondendo, portanto, após o cálculo da média dos dados, à declividade de 6 metros a montante das cabeceiras das feições erosivas. Para a interpretação posterior dos resultados foram utilizados tanto os dados de declividade de 1,5 metros como os dados da média de 6 metros a partir da cabeceira.

A segunda forma de obtenção da declividade, e também a única forma pelo qual foi calculada a área de contribuição nas cabeceiras das feições, baseou-se na geração de um Modelo Digital de Terreno (MDT). Para a confecção do MDT foram utilizadas três cartas topográficas digitais na escala 1:10.000, com curvas de nível com equidistância de cinco metros $^{3}$.

Após a vetorização das curvas de nível, canais de drenagem e pontos cotados dessas cartas, foram gerados três Modelos Digitais de Terreno por meio do módulo Topo to Raster (ferramenta $3 D$ Analyst) do programa ArcMap ${ }^{T M}$ 9.2: o primeiro com resolução de $2 \times 2$ metros $\left(4 \mathrm{~m}^{2}\right)$, a fim de comparação com os dados de declividade de 1,5 metros obtidos em campo; o segundo com resolução de 6x6 metros $\left(36 \mathrm{~m}^{2}\right)$, para comparação com os dados de declividade média (6 metros) obtidos em campo; e o último com resolução de 10x10 metros $\left(100 \mathrm{~m}^{2}\right)$, numa resolução mais apropriada às características da base topográfica utilizada.

A declividade, nos três MDTs gerados, foi obtida por meio do módulo Slope da ferramenta 3D Analyst no programa $\operatorname{ArcMap}^{T M} 9.2$ (Figura 15a). O cálculo da área de contribuição foi feito (para os três MDTs gerados) por meio do modelo matemático SHALSTAB (ferramenta SHALtopo/Contributing Area) no programa ArcView GIS 3.2 (Figura 15b), que calcula a área de contribuição por um método de transferência de fluxo distribuída, que RAMOS et al. (2003), descreve como um método de maior confiabilidade em modelos de previsão de áreas de instabilidade, de processos erosivos, determinação de zonas de saturação na paisagem etc., do que os métodos de transferência de fluxo para uma única célula.

Os dados de declividade e área de contribuição para as cabeceiras e pontos de início das feições erosivas mapeadas nas fotografias aéreas de 1972 também foram obtidos do MDT gerado a partir das cartas topográficas de 1983. Neste caso, foi utilizado apenas o MDT com resolução de 10x10 metros. Acredita-se que ainda que as cartas topográficas sejam posteriores a fotografias aéreas, as feições erosivas não tenham afetado de modo significativo a posição

\footnotetext{
${ }^{3}$ Foram utilizadas as seguintes cartas topográficas: Água da Faca (SF-22-Z-B-I-4-SO-A), Brasília Paulista (SF22-Z-B-I-4-SO-C) e Piratininga II (SF-22-Z-B-I-4-SO-D). As cartas, elaboradas pelo Instituto Geográfico e Cartográfico (Secretaria de Economia e Planejamento do Estado de São Paulo), datam de 1983 e foram cedidas em formato digital pela Prefeitura Municipal de Piratininga.
} 
das curvas de nível, e, consequentemente, não gerem distorções expressivas nos resultados de área de contribuição e declividade.

A extração dos valores de declividade e área de contribuição para todos os layers de pontos das cabeceiras das feições erosivas (em 1972 e atuais) e da localização do início das feições erosivas foi feita pela ferramenta Extract Values to Points (Spatial Analyst Tools/Extraction) no ArcMap ${ }^{T M}$ 9.2.

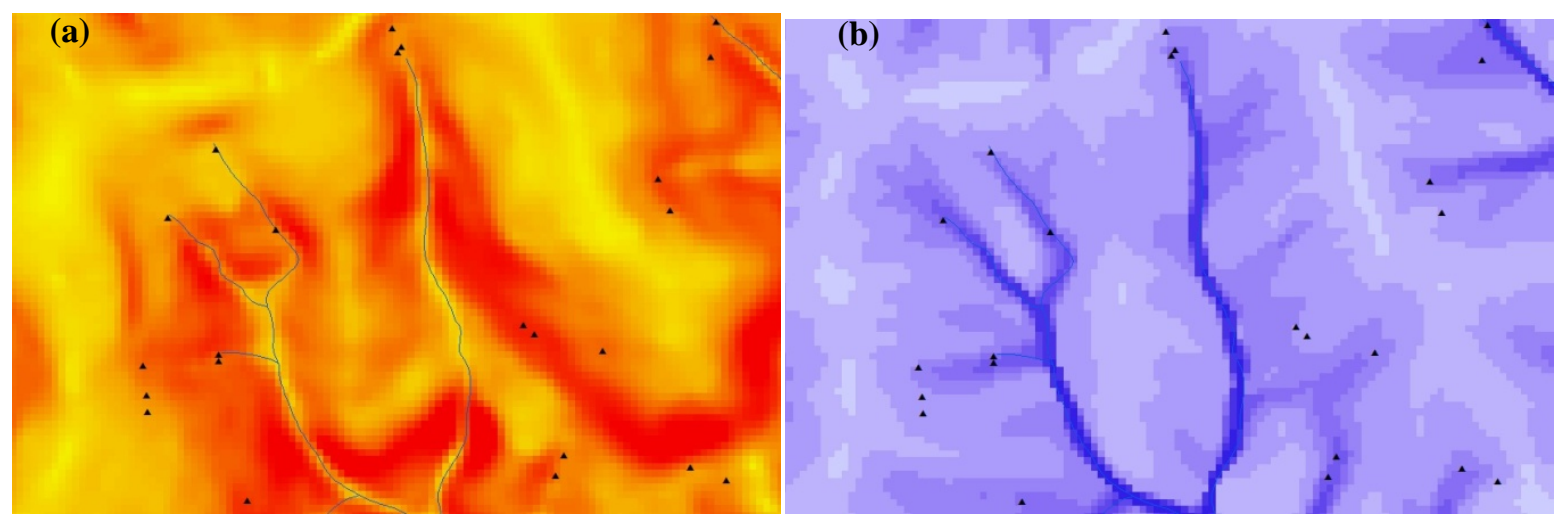

Figura 15: Detalhe na escala 1:10.000 dos mapas de declividade (a) e área de contribuição (b) gerados a partir do MDT com resolução de 10x10 metros em uma das cabeceiras de drenagem estudadas. Os pontos pretos representam a localização das cabeceiras das feições erosivas

\subsection{Definição dos Limites Críticos Topográficos}

A grande maioria dos trabalhos que utilizam a relação entre declividade e área de contribuição para a delimitação de limites críticos topográficos descrevem a relação como uma Função Potência (Power Function), ou seja, uma função com a seguinte forma:

$$
S=a \times A^{b}
$$

onde: $S$ é a declividade da superfície; $A$ é a área de contribuição da cabeceira do canal; e $a$ e $b$ são coeficientes que dependem das características do ambiente.

A definição dos limites críticos nesta pesquisa foi realizada da mesma maneira que o método descrito por VANDAELE et al. (1996) e VANWALLEGUEM et al. (2005). Seguindo tal método, após a plotagem dos dados de S e A no plano cartesiano, foi calculada a 
linha de regressão dos dados que, como afirmado anteriormente, deve ser uma Função Potência. Em seguida, essa linha de regressão foi ajustada no limite inferior de todos os dados, representando assim o limite crítico. Como a linha ajustada é paralela à linha de regressão, o coeficiente $b$ não se altera na nova equação, sendo modificado apenas o coeficiente $a$ (Figura 16).

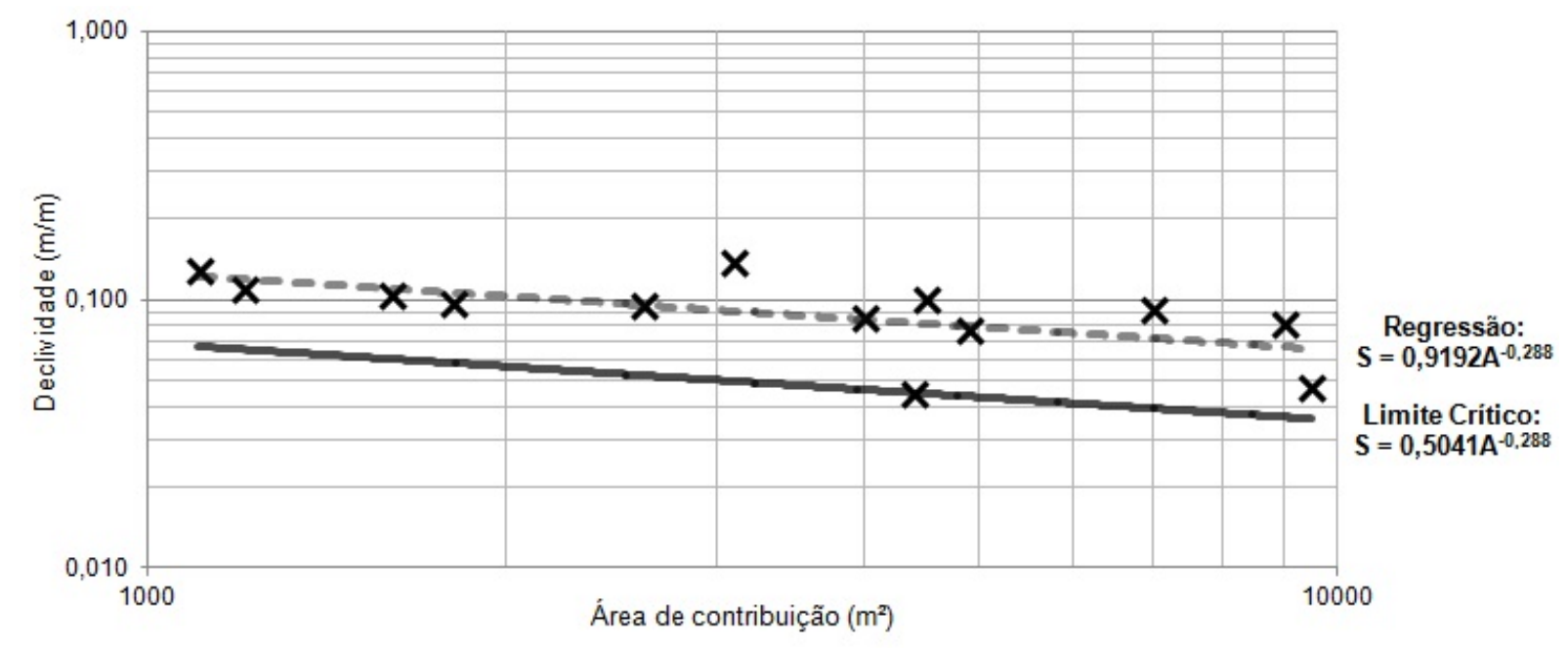

Figura 16:Exemplo hipotético de relação entre S e A. A linha tracejada representa a linha de regressão dos dados, enquanto que a linha contínua representa o limite crítico calculado. Ressalta-se que como o gráfico está em escala logarítmica, ambas as linhas, constituídas por uma Função Potência, aparecem como linhas retas.

Para o cálculo do limite crítico, inicialmente foi calculada a linha de regressão na forma de uma Função Potência. A regressão foi computada automaticamente pelo programa Microsoft Excel 2007, com o uso da ferramenta Linha de Tendência (opção Tipo de Tendência/Regressão: Potência). Desse modo, o programa gerou a forma gráfica da função assim como sua equação, que no caso dessa demonstração é a seguinte:

$$
S=0,9192 \times A^{-0,288}
$$

onde: $S$ é a declividade da superfície logo a montante da cabeceira; $A$ é a área de contribuição da cabeceira do canal; e $a=0,9192$ e $b=-0,288$ são coeficientes que dependem das características do ambiente.

A etapa seguinte envolveu a estimativa do novo coeficiente $a$, visto que o coeficiente $b$ não é alterado na equação do limite crítico. Para isso foi necessário identificar o ponto no 
plano cartesiano que está menos ajustado a linha de regressão na sua parte inferior. No caso desta demonstração, é justamente o ponto sob a linha contínua (4400; 0,045). Cabe destacar que esse ponto simula precisamente o ponto mais próximo do limite crítico, abaixo do qual não ocorre a formação de canais.

Objetivando aferir o coeficiente $a$ do limite crítico, a Equação 2 foi resolvida substituindo as variáveis $\mathrm{S}$ e $\mathrm{A}$ pelos valores correspondentes ao ponto identificado e o coeficiente $b$ pelo coeficiente gerado na regressão, de modo que a incógnita passou a ser o coeficiente $a$, chamado nesta equação de $a_{l c}$ :

$$
0,045=a_{l c} \times 4400^{-0,288}
$$

onde: $a_{l c}$ é o coeficiente de ajuste ao eixo das ordenadas no limite crítico.

Simplificando, a equação passou a ser:

$$
a_{l c}=\frac{0,045}{4400^{-0,288}}
$$

Ou em termos:

$$
a_{l c}=\frac{S_{p}}{A_{p}^{b}}
$$

onde: $a_{l c}$ é o coeficiente de ajuste ao eixo das ordenadas no limite crítico; $S_{p}$ é a declividade da superfície logo a montante da cabeceira do ponto inferior; $A_{p}$ é a área de contribuição da cabeceira do ponto inferior; e $b$ é o coeficiente da curva da Função Potência gerado na regressão dos dados.

A solução da Equação 6, utilizada para demonstração, é 0,5041 , e a equação do limite crítico neste caso é: 


$$
S=0,5041 \times A^{-0,288}
$$

onde: $S$ é a declividade da superfície logo a montante da cabeceira; $A$ é a área de contribuição da cabeceira do canal; e $a=0,5041$ e $b=-0,288$ são coeficientes que dependem das características do ambiente.

Ressalta-se que a proposta de MORGAN e MNGOMEZULU (2003), na qual o limite crítico é identificado a partir de uma análise estatística discriminante entre cabeceiras com ocorrência de erosão e cabeceiras sem erosão, inicialmente havia sido considerada a que gera resultados mais confiáveis, sobretudo por considerar locais sem ocorrência de erosão, resultando, segundo os autores, em limites críticos não exatamente iguais aos gerados pelo método aqui utilizado. Todavia, essa solução só seria possível de ser empregada caso nesta pesquisa estivesse incluído como procedimento o mapeamento das cabeceiras de canais onde não ocorreu o voçorocamento, situação extremamente difícil de encontrar na área de estudo. 


\section{4. ÁREA DE ESTUDO}

A área de estudo é composta por diversas feições erosivas e suas respectivas áreas de contribuição, em uma região constituída por cabeceiras de drenagem na porção central do município de Piratininga, região de Bauru (SP) (Mapa 2). As feições erosivas estudadas estão situadas, portanto, principalmente próximas a canais de primeira ordem, segundo metodologia de Strähler, sobretudo nas porções côncavas do relevo.

As cabeceiras de nordeste são afluentes da Água de Faca, que por sua vez deságua no Rio Batalha, até finalmente chegar ao Rio Tietê. As cabeceiras de sudoeste são afluentes do Rio Alambari, que deságua no Rio Turvo, depois no Rio Pardo, até finalmente chegar ao Rio Paranapanema. Evidencia-se assim que as cabeceiras da área de estudo situam-se em posição topográfica próxima a um importante divisor de águas no Estado de São Paulo, o qual separa as bacias hidrográficas dos rios Tietê e Paranapanema.

O capítulo foi dividido em uma caracterização geral dos aspectos fundamentais para o estudo da erosão (litologia, relevo, clima, solos e dinâmica de ocupação), com base nos principais estudos e mapeamentos já realizados na região (item 4.1), e, em uma segunda parte, onde se busca uma descrição mais detalhada das voçorocas que ocorrem na Bacia Sedimentar do Paraná (setor paulista) e principalmente na região de Bauru (4.2).

\subsection{Caracterização Geral}

O local de estudo está inserido no denominado Planalto Centro-Ocidental (subdivisão do Planalto Ocidental Paulista), morfoescultura definida por ROSS e MOROZ (1997), com um modelado dominante de colinas amplas e baixas em altitudes predominantes de 300 a 600 metros. Contudo, como destaca SALOMÃO (1994), se referindo ao Platô de Bauru, em uma descrição que cabe também à área de estudo desta pesquisa, as bordas do platô constituem relevos de transição, sendo compostas por relevos movimentados em forma de escarpas, morrotes alongados, morrotes isolados e colinas médias. $\mathrm{O}$ autor ainda propõe que as escarpas são sustentadas principalmente pelos arenitos de cimentação carbonática da Formação Marília, enquanto o relevo mais plano (representado na área de estudo apenas pelas colinas mais a jusante) desenvolve-se a mais de 80 metros abaixo do topo das escarpas, configurando uma zona deprimida cujo substrato principal é a Formação Adamantina. 


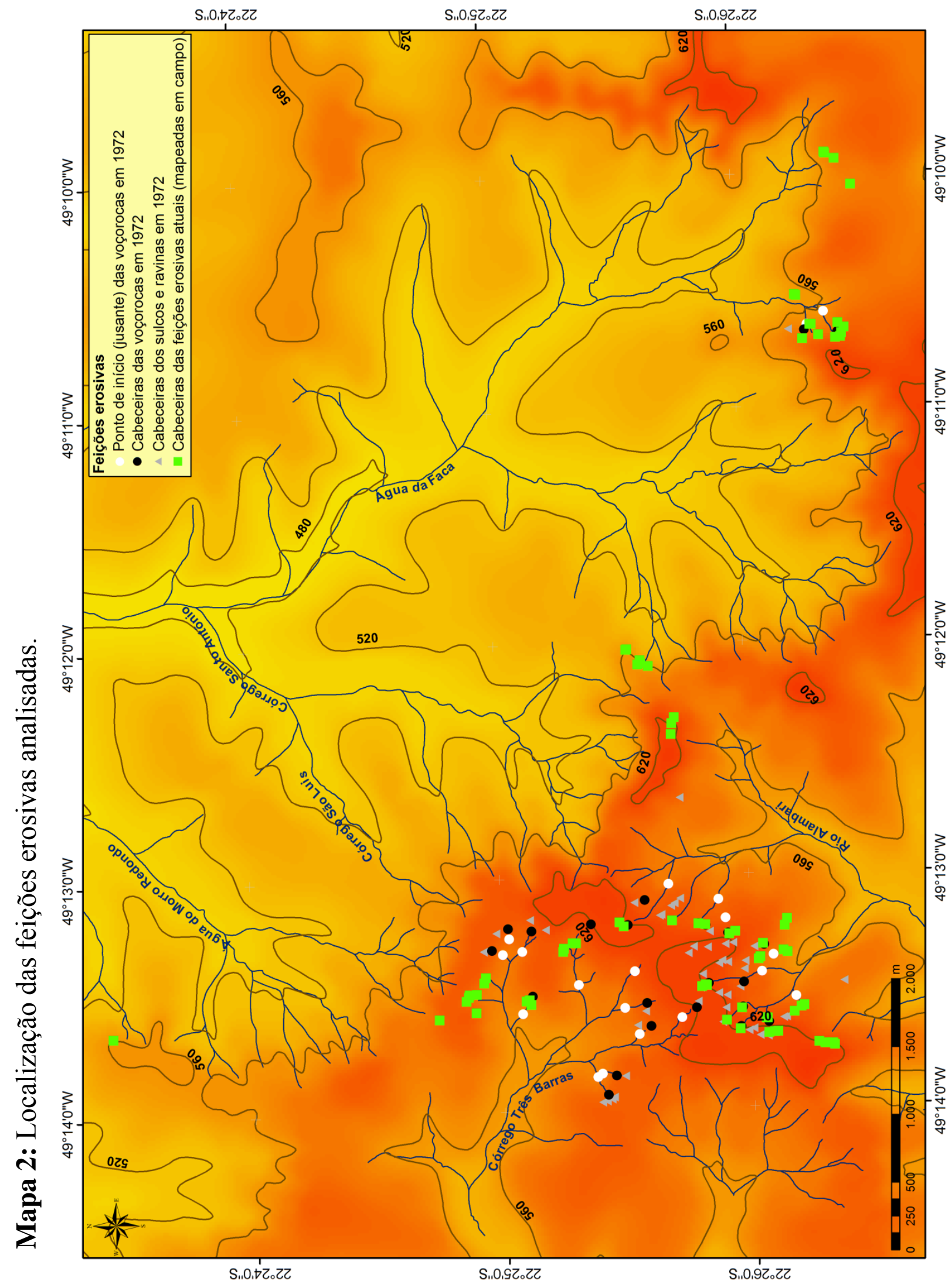


No Mapa 3 pode-se observar a inserção da área de estudo no arcabouço geológico regional, constituído por rochas areníticas do Grupo Bauru e rochas vulcânicas básicas da Formação Serra Geral, depositadas na Bacia Sedimentar do Paraná na Era Mesozóica. Na área de estudo ocorrem predominantemente as rochas da Formação Marília, constituídas por depósitos rudáceos formados por leques aluviais nas margens da bacia, e nas partes mais baixas das encostas afloram as rochas da Formação Adamantina, formadas por depósitos arenosos de sistema fluvial entrelaçado com lagos subordinados (IPT, 1981).

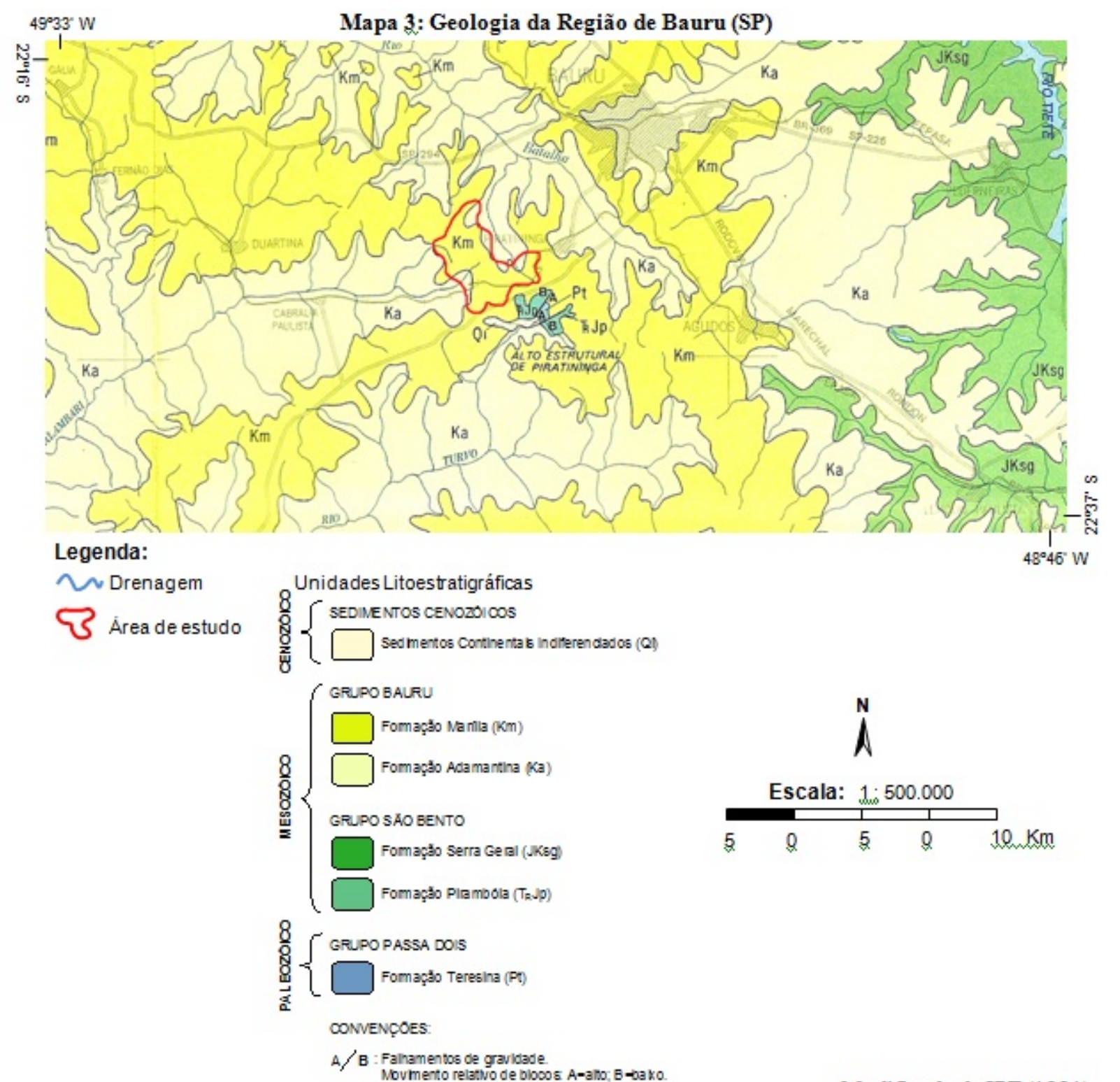

Modifica do de IPT (1981) 
No contexto regional, os basaltos da Formação Serra Geral afloram na região de Bauru apenas nas proximidades dos principais rios, onde o rio Tietê e seus tributários como o rio Bauru, ribeirão dos Patos e rio Lençóis têm seus vales escavados. Por outro lado, a Formação Marília ocorre nos principais divisores de águas da região, nas terras mais altas, compondo estruturas como o Platô de Marília e seus flancos, incluindo as cabeceiras de drenagem que formam a área de estudo deste trabalho. Tais estruturas são responsáveis pela divisão entre as águas que fluem para sudoeste em direção ao rio Paranapanema (rios Turvo e Alambari), para leste em direção ao rio Tietê (rios Bauru e Lençóis) e para norte também com ponto de jusante no rio Tietê (rio Batalha).

Com representatividade mais localizada na região de Bauru afloram a Formação Pirambóia (Grupo São Bento) e a Formação Teresina (Grupo Passa Dois), compondo o denominado Alto Estrutural de Piratininga (IPT, 1981). De acordo com HACHIRO et al. (1994) apud RICCOMINI (1997) estes sedimentos estão associados a um graben anelar, disposto concentricamente uma estrutura de impacto de corpo celeste, designada como Astroblema de Piratininga.

O clima atual da região é tropical de altitude, caracterizado por duas estações alternantes (Cwa conforme a classificação de Köppen) (CATI, 2003). Caracterizando o verão em associação às temperaturas altas está a alta pluviosidade, assim como as relativamente baixas temperaturas de inverno vêm acompanhadas por baixa pluviosidade. Nesse sentido pode-se caracterizar dois períodos marcantes: um de dezembro a fevereiro com mais de $200 \mathrm{~mm}$ de média mensal de chuva e, outro, de junho a agosto com menos de $70 \mathrm{~mm}$ de média mensal de chuva, sendo separados por períodos intermediários de março a maio e setembro a novembro cuja pluviosidade mensal fica, em média, entre 100 e 150 mm (Figura 17).

Associados ao relevo suave e ao clima quente e úmido, na região predominam solos muito desenvolvidos, com alteração pronunciada dos minerais primários: solos com horizonte $\mathrm{B}$ latossólico $(\mathrm{Bl})$ ou com horizonte $\mathrm{B}$ textural $(\mathrm{Bt})$. Solos pouco evoluídos são encontrados apenas localmente, em condições específicas do meio: solos hidromórficos em ambientes de agradação mal drenados ou solos litólicos em relevos com alta declividade (SALOMÃO, 1994). 


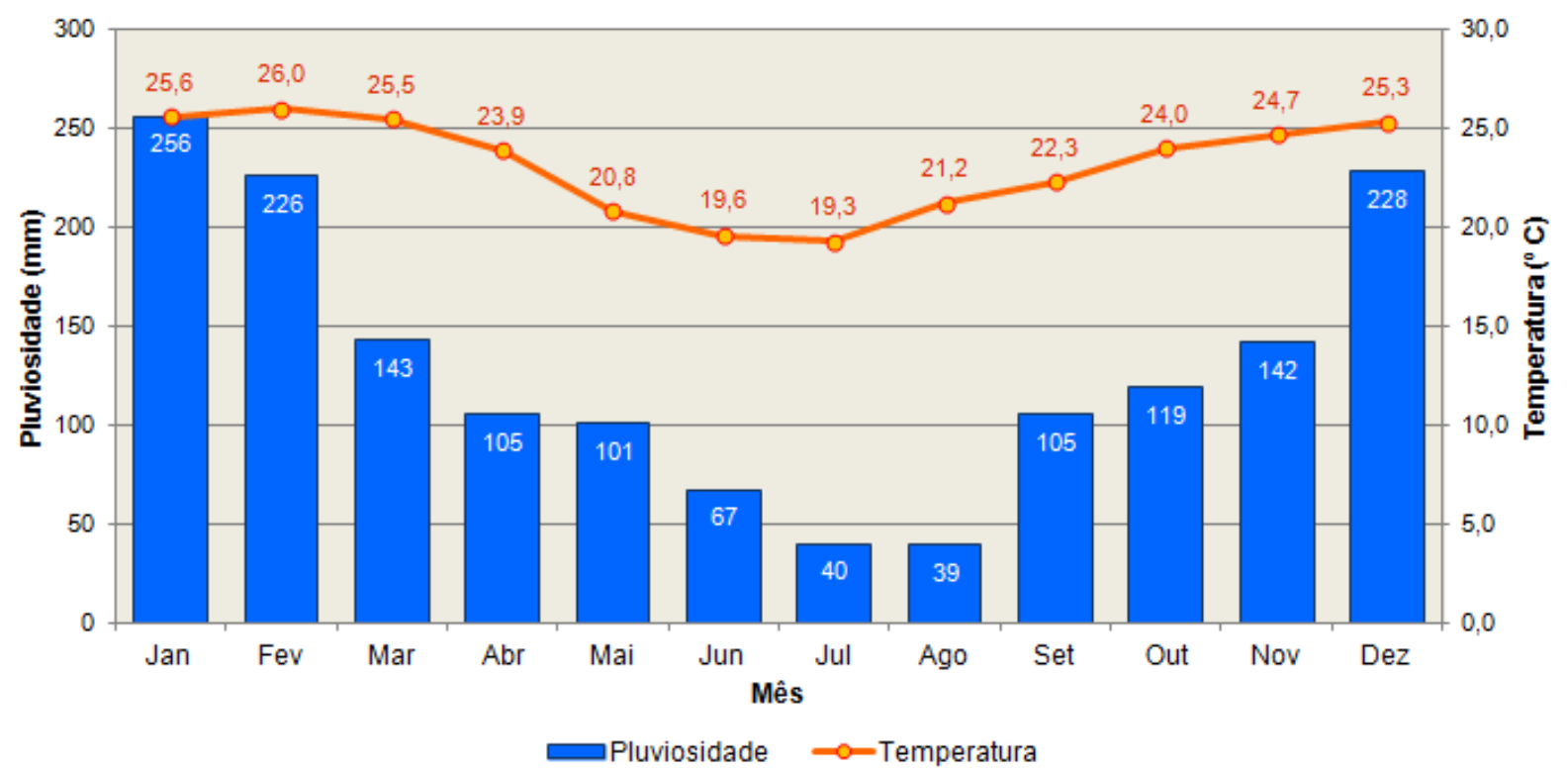

Figura 17 Média mensal de temperatura e pluviosidade (Piratininga-SP). Fonte: Interpolação de dados de temperatura do CIIAGRO (Bauru: 1995 a 2008; e Santa Cruz do Rio Pardo: 1993 a 2008) e do IAC (Jaú: 1971 a 1999); dados pluviométricos do SIGRH/DAEE (SP), série histórica de 1980 a 1997 (Posto D6-022, 530m, Bacia do Batalha, Lat. $22^{\circ} 25^{\prime}$, Long. $\left.49^{\circ} 08^{\prime}\right)$.

SALOMÃO (1994), SANTOS (1995), SANTOS et al. (2001) e SANTOS e CASTRO (2006) avaliaram a complexidade da dinâmica dos solos na região de Bauru, demonstrando inclusive o papel da cobertura pedológica na dinâmica físico-hídrica das encostas e na própria evolução do relevo. Neste sentido, SALOMÃO (1994), ao caracterizar o comportamento físico hídrico de alguns sistemas pedológicos na região de Bauru, analisou as mudanças na dinâmica dos fluxos d'água entre os Latossolos, nos quais a drenagem interna é principalmente vertical e profunda, e os Argissolos, onde a drenagem interna passa a ter um direcionamento lateral acima do horizonte B textural, contribuindo para a formação de processos de piping.

Para SANTOS (1995), os Latossolos poderiam constituir, de fato, a cobertura pedológica inicial, a partir da qual se ocorreram as transformações pedogenéticas superficiais e subsuperficiais, originando, por exemplo, os horizontes B texturais. Segundo SALOMÃO (1994) essa evolução da cobertura pedológica estaria relacionada a modificações em variáveis externas ao sistema (climáticas ou tectônicas), levando a um desequilíbrio hidrológico, cujo resultado seria a expansão das cabeceiras de drenagem e adaptação das encostas e, como consequência, um ajustamento da cobertura pedológica às novas condições. 
A associação entre os elementos do meio físico e os solos, bem como sua relação com as condições de circulação hídrica e o comportamento em relação à erosão é sintetizada por SALOMÃO (1994) no "Mapa de Sistemas Pedológicos", sendo que das seis classes propostas pelo autor, duas delas predominam na área de estudo (apenas as cabeceiras de drenagem afluentes da Água da Faca coincidem com o limite da pesquisa de SALOMÃO (1994):

- Sistema SP-IID (Latossolo-Argissolo-Gleissolo): unidade com restrita ocorrência de Latossolo nos topos, enquanto o Argissolo predomina na vertente. Nestas áreas a erosão é favorecida pelo aumento da declividade. Além disso, de acordo com o autor, nas proximidades da escarpa, a pequena espessura do solo acentua as diferenciações morfológicas da cobertura pedológica, o que permite o desenvolvimento de fluxos subsuperficiais e surgências d'água, onde os altos gradientes hidráulicos possibilitam o piping e o voçorocamento, porém limitado a pequenas profundidades.

- Sistema SP-III (Solos Rasos + Afloramento de Rocha-Argissolo-LatossoloGleissolo): ocupa as escarpas e principais cabeceiras. Caracterizado por uma espessa cobertura arenosa que aumenta de montante para jusante recobrindo quase toda a vertente e por altas declividades, esse sistema tem a concentração de fluxos superficiais e subsuperficiais facilitada. Apresenta também rupturas côncavas, delimitando anfiteatros de encosta, sendo estes muito sensíveis ao voçorocamento. Além disso, as ravinas igualmente ocorrem em grande densidade, favorecidas pelas altas declividades.

Sobre a dinâmica de uso e ocupação do solo, SALOMÃO (1994) propõe que a própria remoção da cobertura vegetal original já teria promovido o desenvolvimento de voçorocas de reativação de cabeceiras de drenagem. Na região de Bauru, o desmatamento da cobertura vegetal, constituída inicialmente, segundo CATI (2004), pela Floresta Estacional Semidecidual e por manchas de Cerrado, está associado à expansão cafeeira no estado de São Paulo no início do século XX (SANTOS et al., 2001), quando de 1900 a 1930 as florestas do estado passaram de $60 \%$ para $28 \%$ de sua área (QUEIROZ NETO, 2001). De acordo com SALOMÃO (1994) esta cultura que não contemplava quaisquer práticas conservacionistas, bem como a implantação de ferrovias e rodovias no início do século, deram origem a outra parte das feições erosivas existentes na área.

Após a crise de 1929, houve um recuo na taxa de desflorestamento e o café foi sendo substituído gradativamente por culturas como o algodão e por áreas de pastagem, de modo 
que, atualmente, estas predominam como uso do solo na região, com cultivos agrícolas restritos aos topos mais planos, manchas de eucalipto em algumas encostas e com a ocorrência de vegetação nativa secundária nas escarpas e outras áreas de maior declividade. No entanto, de acordo com SALOMÃO (1994), mesmo um uso do solo considerado mais protetor como a pastagem, tem provocado intensa dinâmica superficial em algumas áreas mais frágeis.

\subsection{Voçorocas na Bacia Sedimentar do Paraná e na Região de Bauru}

Para a descrição dos processos erosivos da área de estudo, optou-se pela utilização dos trabalhos realizados na região de Bauru, mas também de outras importantes análises que muito contribuem para a compreensão dos processos erosivos na Bacia Sedimentar do Paraná como, por exemplo, os trabalhos de VIEIRA (1978) em Franca (SP) e FURLANI (1980) em Casa Branca (SP). Pressupõe-se para tanto que a dinâmica das feições erosivas observadas nesses trabalhos se assemelhe, ao menos em parte, aos processos deflagração e desenvolvimento das feições erosivas lineares na área de estudo.

As feições erosivas que mais se destacam na região de Bauru, tanto por suas dimensões como por sua frequência de ocorrência, são as voçorocas. A maior parte dos processos descritos no item 2.2 pode ser encontrada nas voçorocas, visto serem formas de relevo geradas por um conjunto de processos morfogenéticos (VIEIRA, 1978), como demonstra a Figura 18, onde está esquematizada a parede de uma das voçorocas estudadas por FURLANI (1980). Todavia, à medida que a voçoroca passa por diferentes estágios, que vão da incisão inicial, ao alargamento e intensa atividade erosiva e, enfim, à estabilização, os processos atuantes tendem a sofrer mudanças quantitativas e qualitativas (VIEIRA, 1978).

FURLANI (1980) relata que após a incisão, ruptura ou desabamento inicial que desencadeia o processo erosivo, normalmente na baixa encosta, a voçoroca, por meio de processos remontantes, rasga um corredor até os setores mais elevados das colinas, instalando um perfil longitudinal em rampa larga e suave. A ativação dos principais processos erosivos responsáveis pelo recuo das cabeceiras ocorre durante a estação chuvosa, quando há o aumento tanto do escoamento superficial como do subterrâneo por meio de rápidas subidas do lençol freático, resultando na formação e evolução de túneis (piping) e na ocorrência de diversas tipologias de movimentos de massa (VIEIRA, 1978; FURLANI, 1980; SALOMÃO, 1994). 


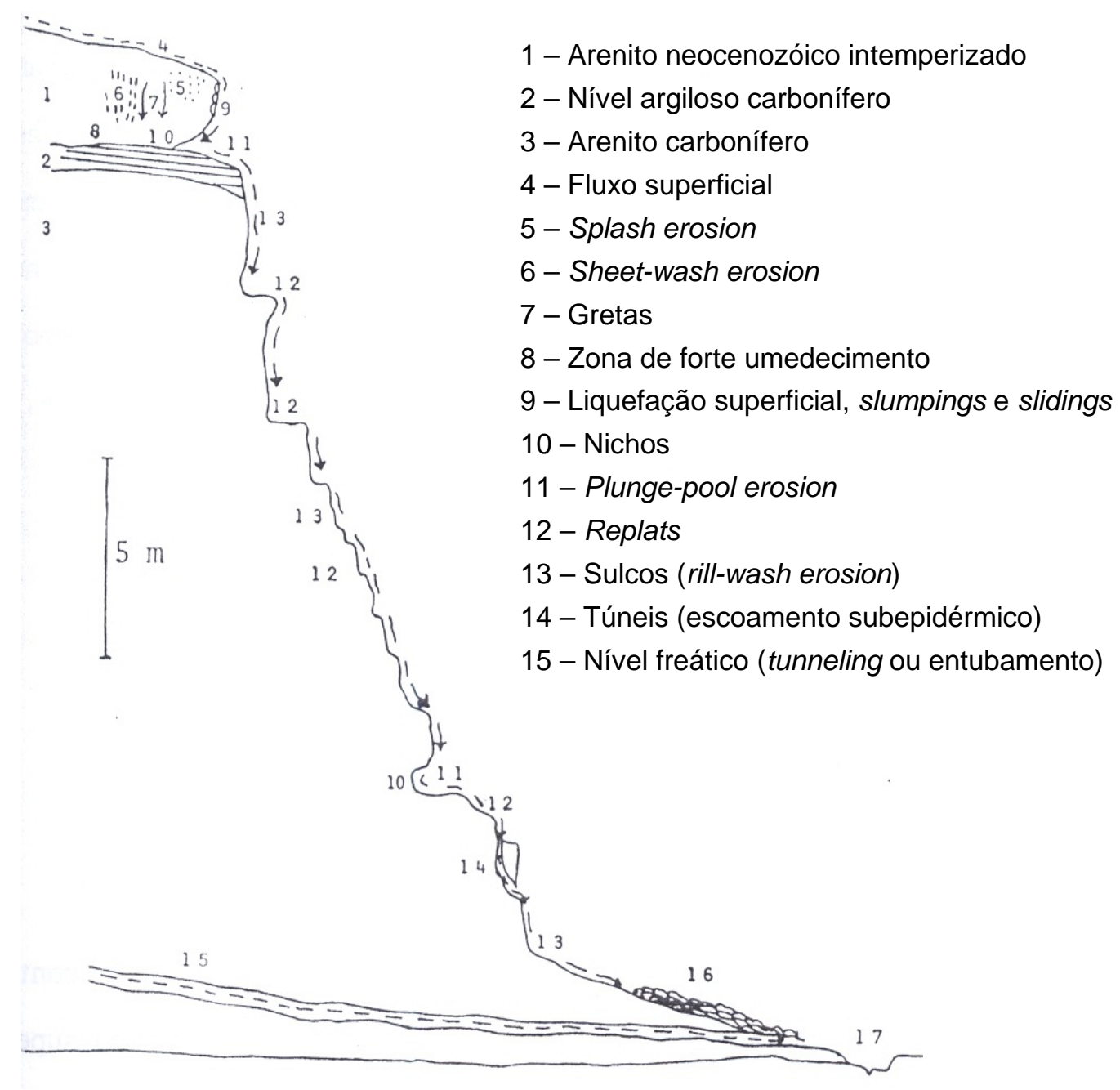

Figura 18: Esquema de parede da voçoroca Senhor Menino em Casa Branca (SP) demonstrando a variedade de processos morfogenéticos que ocorrem em um voçorocamento. Modificada de FURLANI (1980)

CASTRO e QUEIROZ NETO (2009) relatam que o gatilho para o início do desenvolvimento das voçorocas no Planalto Ocidental Paulista foi o desflorestamento da vegetação nativa (Floresta Estacional Semidecidual do domínio Mata Atlântica) na primeira metade do século XX, descrevendo que após o estabelecimento da agricultura foi observado um decréscimo nas taxas de erosão. SALOMÃO (1994) faz conclusões semelhantes a respeito das feições erosivas profundas em cabeceiras de drenagem na região de Bauru, e explica que sua provável origem é consequência de alterações hidrológicas que provocaram maior aporte de águas de escoamento superficial, causando aprofundamento e alargamento das calhas dos 
rios, e deixando expostas surgências d'água ao longo dos fundos de vale, em barrancos e mesmo na encosta.

$\mathrm{Na}$ região de Bauru ocorre ainda outro tipo de voçorocamento, originado da concentração do escoamento superficial. Nessas condições, o processo erosivo inicia-se em superfície, através do ravinamento, podendo, por aprofundamento da ravina, atingir o lençol freático (SALOMÃO, 1994).

Ao estudarem as feições erosivas (incluindo outros tipos além das voçorocas, como as ravinas) da bacia Água da Faca em Piratininga (SP), também na região de Bauru em local que inclui parte da área desta pesquisa, STABILE (2009), STABILE e VIEIRA (2009a) e STABILE e VIEIRA (2009b), constataram uma relação muito forte entre a ocorrência das feições erosivas e a declividade, com o aumento do índice denominado Potencial de Erosão (PE), ou seja, a área relativa de uma classe de um parâmetro (declividade, curvatura, etc.) ocupada pela erosão linear, em acordo com o aumento da declividade. A exceção, segundo os autores, seriam as declividades mais altas (acima de 15 graus) que tem um menor PE, justificado pela manutenção da vegetação original e menores taxas de ocupação antrópica nestes locais, entre outras hipóteses (Figura 19a). Os autores verificaram ainda o maior Potencial de Erosão em encostas côncavas em planta (Figura 19b).

Sobre o estágio de desenvolvimento das feições erosivas encontradas na região, SALOMÃO (1994) e ALMEIDA FILHO (2000) corroboram que o seu máximo desenvolvimento se deu em torno do ano de 1972, quase não sendo observadas novas feições ou mesmo o aumento das feições já existentes. Por conseguinte, pode-se considerar que boa parte das feições erosivas está próxima de uma condição de estabilidade ou mesmo já estabilizada.

(a)

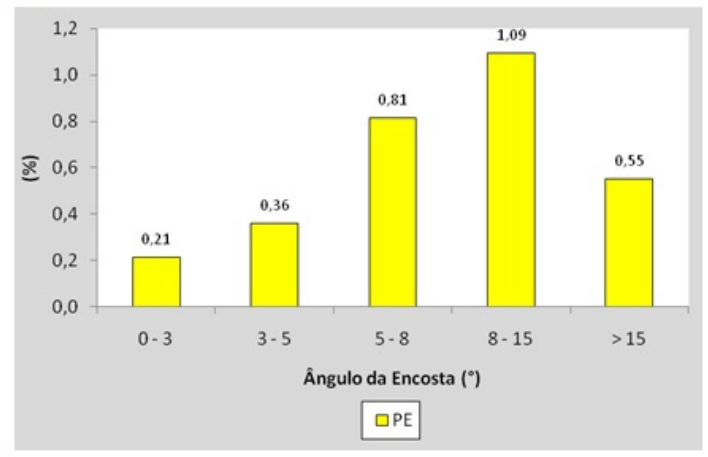

(b)

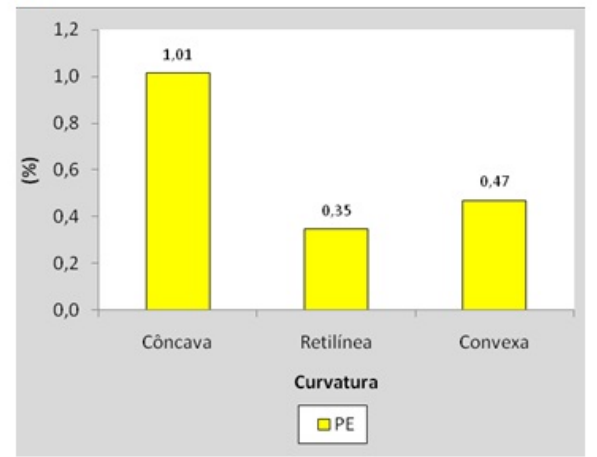

Figura 19: Potencial de Erosão (PE) para as classes de declividade (a) e curvatura em planta (b) na bacia da Água da Faca. STABILE (2009) 


\section{RESULTADOS E DISCUSSÕES}

A apresentação dos resultados inicia-se pela análise da variabilidade e das tipologias das feições erosivas estudadas, bem como suas principais características e dinâmica (item 5.1). Em seguida, discutem-se os resultados das medições de declividade em campo com o uso do pantômetro e das informações de declividade e área de contribuição geradas pelo MDT, e também a avaliação dos resultados das diferentes resoluções de MDT (5.2). Por fim, chega-se ao objetivo geral da pesquisa, com a avaliação dos limites críticos topográficos para o desenvolvimento da erosão linear na área de estudo (5.3); com o diagnóstico da relação dos limites críticos com a estabilidade e instabilidade das feições erosivas (5.4); com a análise das consequências para a deflagração e desenvolvimento inicial das voçorocas (5.5); e com a avaliação das relações com a classificação das feições erosivas (5.6).

\subsection{Feições Erosivas}

A partir da análise das feições erosivas na área de estudo, foi verificada a sua ampla variedade, seja pela forma, pelos processos, pelo estágio de desenvolvimento, ou pelo ambiente de formação.

Em um esforço de classificação, as cabeceiras das feições erosivas foram divididas em quatro classes principais, sendo que cada uma dessas classes apresenta subconjuntos, totalizando 13 categorias, descritas na Tabela 3. Na Figura 20 as 73 cabeceiras atuais analisadas foram contabilizadas de acordo com a categoria estabelecida. 


\begin{tabular}{|c|c|c|c|c|}
\hline \multicolumn{5}{|c|}{ Tabela 3 Síntese das categorias de feições erosivas na área de estudo } \\
\hline Classe & Subclasse & Forma atual & Processos atuais & Evolução desde 1972 \\
\hline \multirow{3}{*}{ 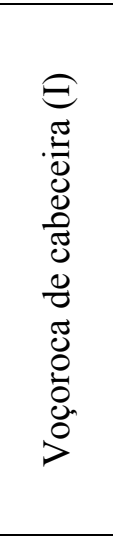 } & 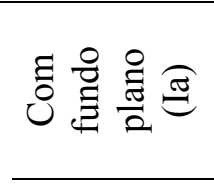 & $\begin{array}{l}\text { Feição linear em planta, } \\
\text { com cabeceiras abruptas, } \\
\text { fundo plano e grande } \\
\text { dimensão relativa. }\end{array}$ & $\begin{array}{l}\text { Solapamentos frequentes } \\
\text { nas cabeceiras, indícios de } \\
\text { piping e, às vezes, } \\
\text { escoamento superficial. }\end{array}$ & $\begin{array}{c}\text { Estável, com crescimento } \\
\text { de arbustos e gramíneas no } \\
\text { fundo. Raramente, ocorreu } \\
\text { desenvolvimento alguns } \\
\text { metros a montante. }\end{array}$ \\
\hline & 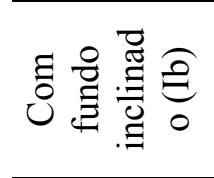 & $\begin{array}{l}\text { Feição linear em planta, } \\
\text { com cabeceiras e fundo } \\
\text { inclinados (presença de } \\
\text { arenito) e grande dimensão } \\
\text { relativa. }\end{array}$ & $\begin{array}{c}\text { Poucos processos ativos, } \\
\text { normalmente quedas de } \\
\text { blocos na cabeceira e } \\
\text { pequenos solapamentos no } \\
\text { corpo. }\end{array}$ & $\begin{array}{l}\text { Estável, com crescimento } \\
\text { de arbustos e gramíneas no } \\
\text { fundo. }\end{array}$ \\
\hline & 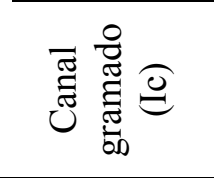 & $\begin{array}{l}\text { Canal totalmente gramado } \\
\text { com borda suave, fundo } \\
\text { levemente inclinado, em } \\
\text { geral a montante da feição } \\
\text { Ia. }\end{array}$ & $\begin{array}{l}\text { Sem indícios de processos } \\
\text { de evolução atuais. }\end{array}$ & $\begin{array}{l}\text { Suavização da cabeceira, } \\
\text { paredes e sulcos } \\
\text { perpendiculares com } \\
\text { crescimento de gramíneas } \\
\text { na feição toda. }\end{array}$ \\
\hline \multirow{6}{*}{ 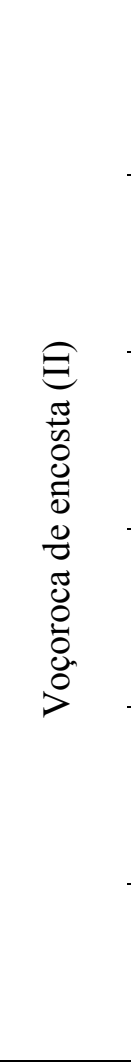 } & 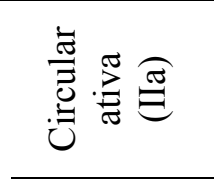 & $\begin{array}{l}\text { Feição circular em planta, } \\
\text { com fundo irregular e muito } \\
\text { material solapado próximo } \\
\text { à cabeceira. }\end{array}$ & $\begin{array}{c}\text { Solapamentos } \\
\text { generalizados nas } \\
\text { cabeceiras, às vezes piping } \\
\text { e com pouca frequência } \\
\text { escoamento superficial. }\end{array}$ & $\begin{array}{c}\text { Em estágio inicial em } 1972 . \\
\text { Em um caso, havia outra } \\
\text { tipologia de feição no } \\
\text { mesmo local. }\end{array}$ \\
\hline & 离 & $\begin{array}{c}\text { Feição circular em planta, } \\
\text { com fundo plano a } \\
\text { inclinado próximo à } \\
\text { cabeceira. }\end{array}$ & $\begin{array}{l}\text { Sem indícios de processos } \\
\text { de evolução atuais, diversos } \\
\text { blocos solapados já } \\
\text { estabilizados. }\end{array}$ & $\begin{array}{l}\text { Inexistente ou em estágio } \\
\text { inicial em } 1972 .\end{array}$ \\
\hline & 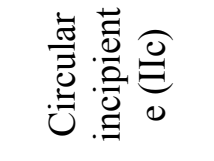 & $\begin{array}{c}\text { Feição com forma irregular, } \\
\text { próxima à circular, com } \\
\text { paredes e fundo cobertos } \\
\text { por gramíneas. }\end{array}$ & $\begin{array}{l}\text { Sem indícios de processos } \\
\text { de evolução atuais. }\end{array}$ & $\begin{array}{l}\text { Inexistente em 1972. Em } \\
\text { um caso, havia outra } \\
\text { tipologia de feição no } \\
\text { mesmo local. }\end{array}$ \\
\hline & 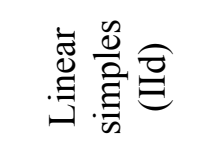 & $\begin{array}{l}\text { Feição linear em planta, } \\
\text { com cabeceiras abruptas, } \\
\text { fundo plano e pequena } \\
\text { dimensão relativa. }\end{array}$ & $\begin{array}{l}\text { Solapamentos nas } \\
\text { cabeceiras, indícios de } \\
\text { piping e escoamento } \\
\text { superficial. }\end{array}$ & Em estágio inicial em 1972. \\
\hline & 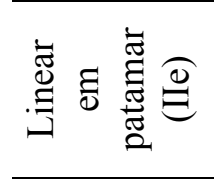 & $\begin{array}{l}\text { Feição linear em planta, } \\
\text { com fundo em patamares e } \\
\text { com alcovas e incisões } \\
\text { frequentes no fundo. }\end{array}$ & $\begin{array}{c}\text { Sinais frequentes de } \\
\text { escoamento superficial } \\
\text { (plunge pool nos patamares } \\
\text { e incisões). }\end{array}$ & $\begin{array}{l}\text { Aparentemente estabilizada } \\
\text { em 1972, com cobertura } \\
\text { vegetal. Não aumentou de } \\
\text { tamanho desde então, mas } \\
\text { parece mais ativa. }\end{array}$ \\
\hline & 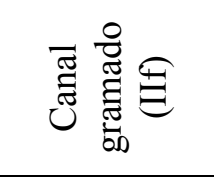 & $\begin{array}{l}\text { Diversas formas de feições } \\
\text { com fundo coberto por } \\
\text { gramíneas, normalmente a } \\
\text { montante de outras feições } \\
\text { do tipo II. }\end{array}$ & $\begin{array}{c}\text { Sem indícios de processos } \\
\text { de evolução atuais. }\end{array}$ & $\begin{array}{l}\text { Varia de acordo com a } \\
\text { feição: se estabilizaram, já } \\
\text { estavam estabilizadas ou } \\
\text { surgiram posteriormente. }\end{array}$ \\
\hline \multicolumn{2}{|c|}{ 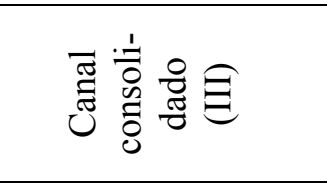 } & $\begin{array}{l}\text { Feição linear conectada à } \\
\text { rede de drenagem, com } \\
\text { cabeceira abrupta e } \\
\text { vegetação arbóreo-arbustiva } \\
\text { no interior e entorno. }\end{array}$ & $\begin{array}{l}\text { Sem indícios de processos } \\
\text { de evolução atuais. }\end{array}$ & $\begin{array}{l}\text { Varia de acordo com a } \\
\text { feição: estabilização, com } \\
\text { crescimento de vegetação } \\
\text { na feição ou já estava } \\
\text { estabilizada. } \\
\end{array}$ \\
\hline \multirow{3}{*}{ 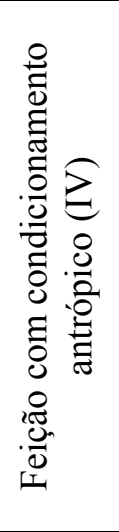 } & 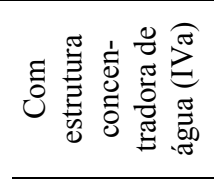 & $\begin{array}{l}\text { Feição linear com bordas } \\
\text { suaves e cobertas por } \\
\text { gramíneas associada à } \\
\text { concentração de água por } \\
\text { estruturas antrópicas. } \\
\end{array}$ & $\begin{array}{l}\text { Sem indícios de processos } \\
\text { de evolução atuais, a } \\
\text { estrutura que concentra } \\
\text { água muitas vezes não } \\
\text { existe mais. } \\
\end{array}$ & $\begin{array}{l}\text { Suavização da cabeceira d } \\
\text { paredes, com crescimento } \\
\text { de gramíneas na feição } \\
\text { toda. }\end{array}$ \\
\hline & 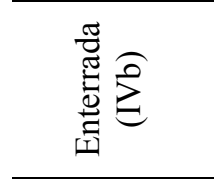 & $\begin{array}{l}\text { Diversas formas de feições } \\
\text { que foram parcialmente ou } \\
\text { totalmente enterradas. }\end{array}$ & $\begin{array}{l}\text { Varia por feição, frequentes } \\
\text { sinais de escoamento } \\
\text { superficial e poucos } \\
\text { solapamentos. }\end{array}$ & $\begin{array}{l}\text { Feições intactas em } 1972 . \\
\text { Parte do canal da feição } \\
\text { ainda existe (talvez tenha } \\
\text { reaparecido) e apresenta } \\
\text { sinais de atividade. } \\
\end{array}$ \\
\hline & 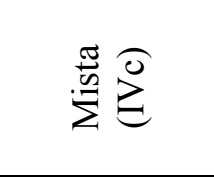 & $\begin{array}{c}\text { Feição que agrega as } \\
\text { características de IVa e } \\
\text { IVb. }\end{array}$ & $\begin{array}{c}\text { Varia por feição, } \\
\text { normalmente sem indícios } \\
\text { de processos, quando } \\
\text { ocorrem predomina o } \\
\text { escoamento superficial. }\end{array}$ & $\begin{array}{c}\text { Enterrada total ou } \\
\text { parcialmente. Quando } \\
\text { ainda existe parte da feição, } \\
\text { ocorreu sua estabilização. }\end{array}$ \\
\hline
\end{tabular}




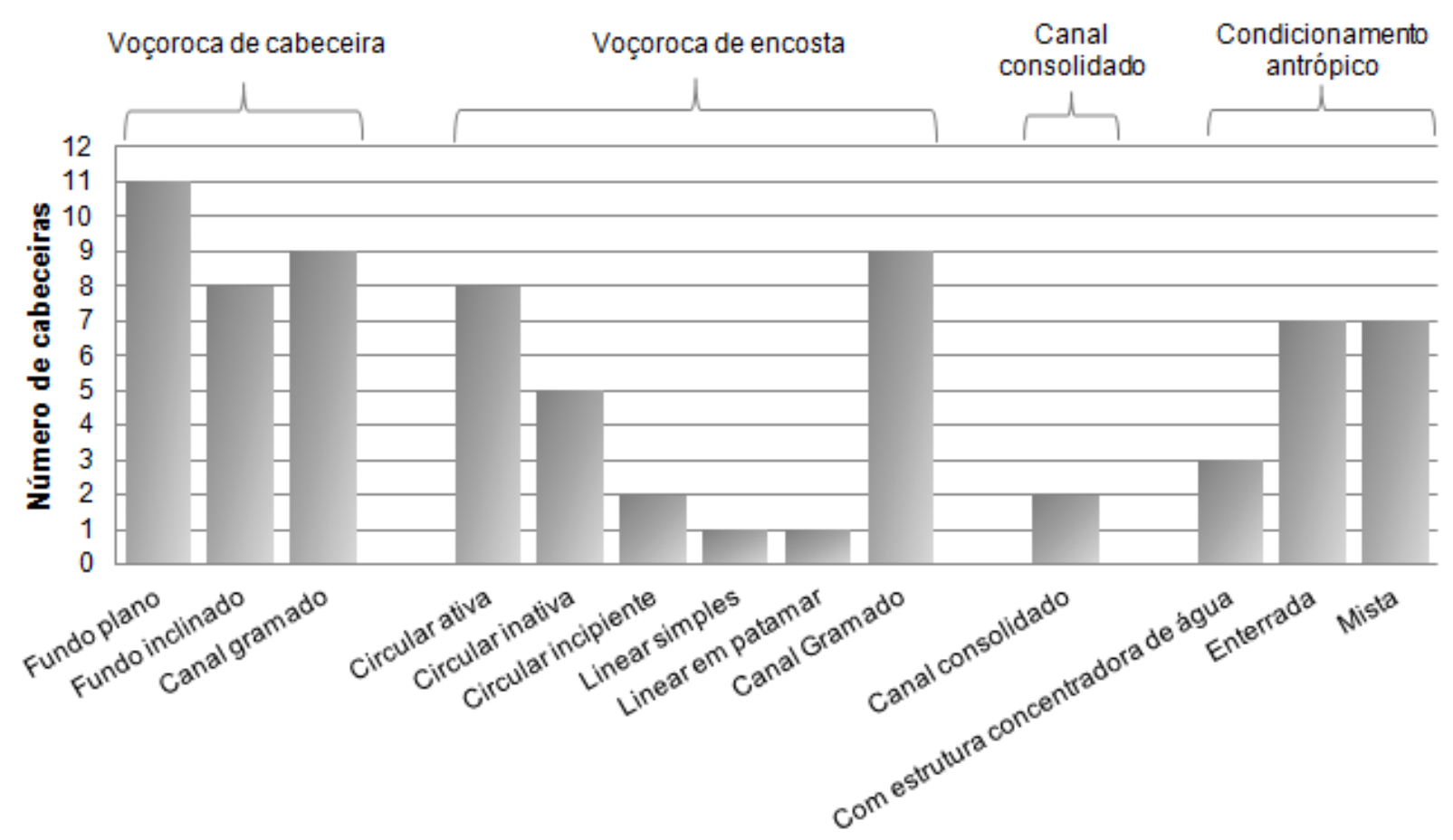

Figura 20: Distribuição das 73 cabeceiras de feições erosivas atuais estudadas de acordo com a classificação proposta.

Um ponto importante do trabalho de classificação é que uma mesma feição erosiva pode apresentar cabeceiras dispostas em classes diferentes. Essa condição ocorre especialmente quando apenas uma das cabeceiras da feição foi incluída na classe IV, ou seja, somente uma das cabeceiras teve sua forma condicionada por atividades antrópicas (como a concentração do escoamento superficial ou o enterramento), ou, nos frequentes casos em que as cabeceiras denominadas de canal gramado (subclasses Ic e IIf) situam-se a montante de outras subclasses de cabeceira na mesma feição erosiva, como foi ilustrado na Figura 11 (item 3.2).

Uma segunda ressalva a ser feita, é que as classes apresentadas representam unicamente as feições erosivas atuais, visto que é muito difícil inferir os processos predominantes em 1972. Sobre isso, duas condições devem ser explicadas:

- No ano de 1972, alastravam-se na área de estudo inúmeros sulcos, provavelmente formados pelo escoamento superficial, mormente a montante das feições erosivas maiores. Esses sulcos dispunham-se concentricamente às cabeceiras e ao corpo das voçorocas e na maioria das vezes estavam conectados às feições de jusante (Figura 21). Atualmente, quase não se observam sulcos junto aos voçorocamentos. 


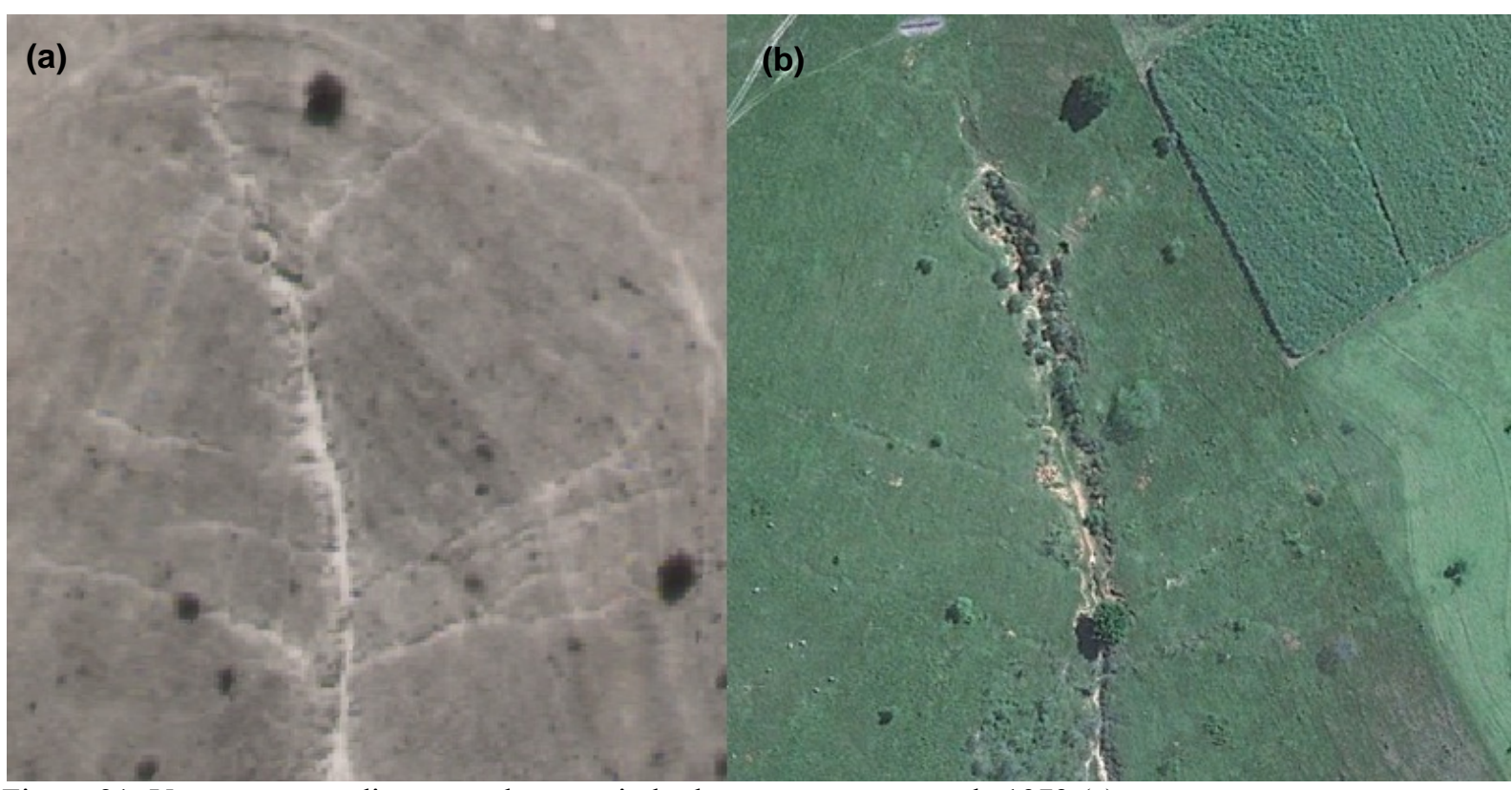

Figura 21: Voçoroca com diversos sulcos partindo de seu corpo no ano de 1972 (a), e a mesma voçoroca no ano de 2010, onde se observa que os sulcos estão suavizados ou desapareceram (b). Escala aproximada: 1:4.000. Fontes: Instituto Brasileiro do Café (1972) e Google Earth.

- Muitas das cabeceiras classificadas nas subclasses Ic (canal gramado das voçorocas de cabeceira) tratavam-se de feições ativas em 1972, com pouca distinção em relação às demais feições da classe I, com exceção de certos aspectos morfométricos como menor profundidade e largura (Figura 22). Nesses casos, para fins das análises posteriores dos limites críticos em 1972, tais cabeceiras foram agrupadas às feições do tipo Ia.

O critério inicial de separação dos tipos de cabeceira foi identificar aquelas em que houve uma forte subordinação dos processos de deflagração ou desenvolvimento da feição erosiva a atividades antrópicas (classe IV). $\mathrm{Na}$ área de estudo, podem ser descritas três situações principais:

- A concentração de escoamento superficial por estradas, caminhos rurais ou ferrovias, resultando na deflagração, a jusante ou até mesmo na própria estrutura, de feições erosivas retilíneas, não muito profundas e relativamente largas (classe IVa). Essas formas apresentavam-se muito ativas em 1972, mas atualmente encontram-se estabilizadas, com bordas suaves e totalmente cobertas por gramíneas (Figura 23). Na maior parte dos casos a estrutura que promoveu a deflagração do processo não existe mais; 


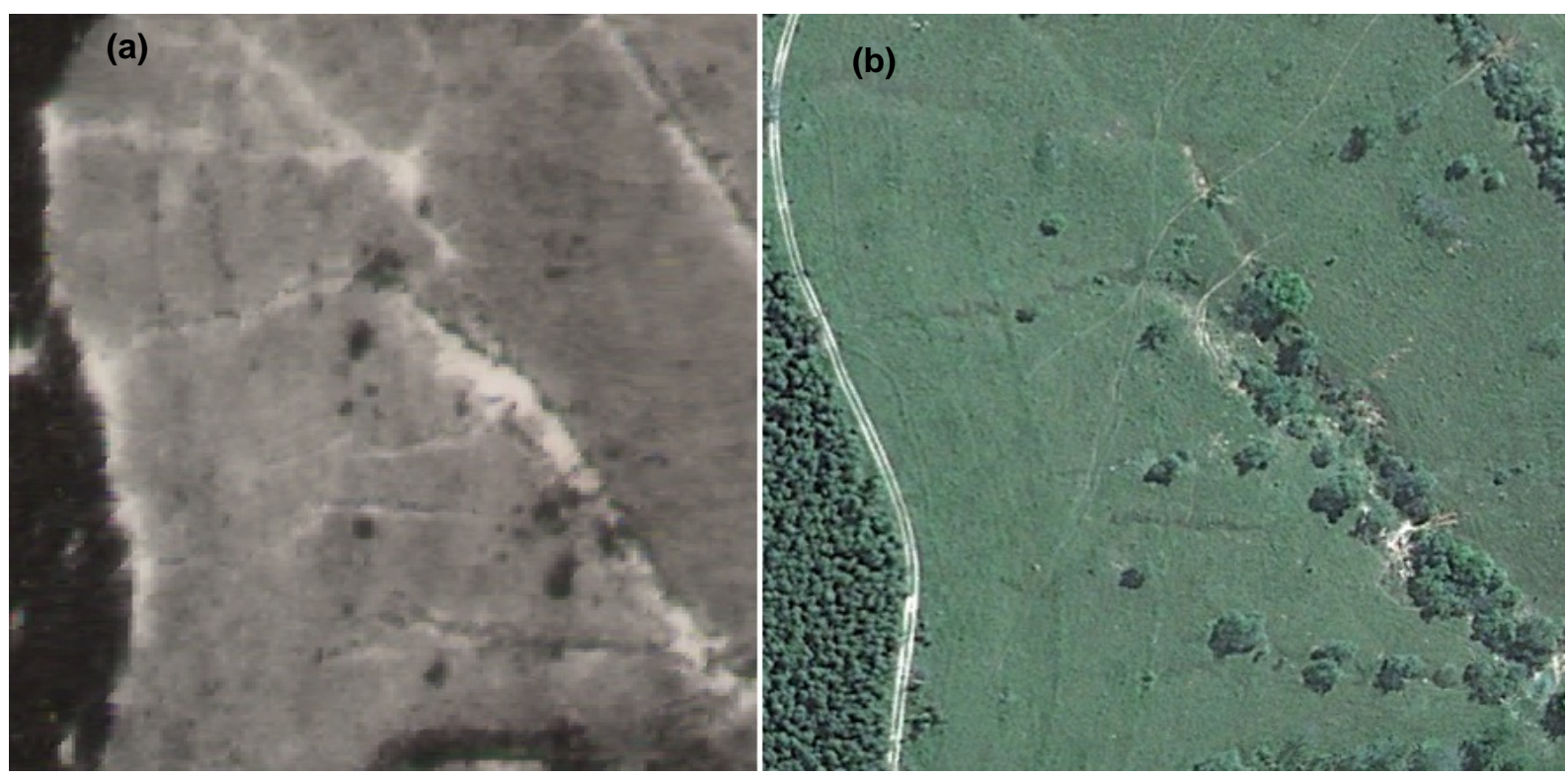

Figura 22 Canal gramado no ano de 1972, quando ainda era uma feição ativa (voçoroca de cabeceira com fundo plano) (a), e a mesma feição em 2010, coberta por vegetação e com bordas suaves (b). Escala aproximada: 1:2.000. Fontes: Instituto Brasileiro do Café (1972) e Google Earth.

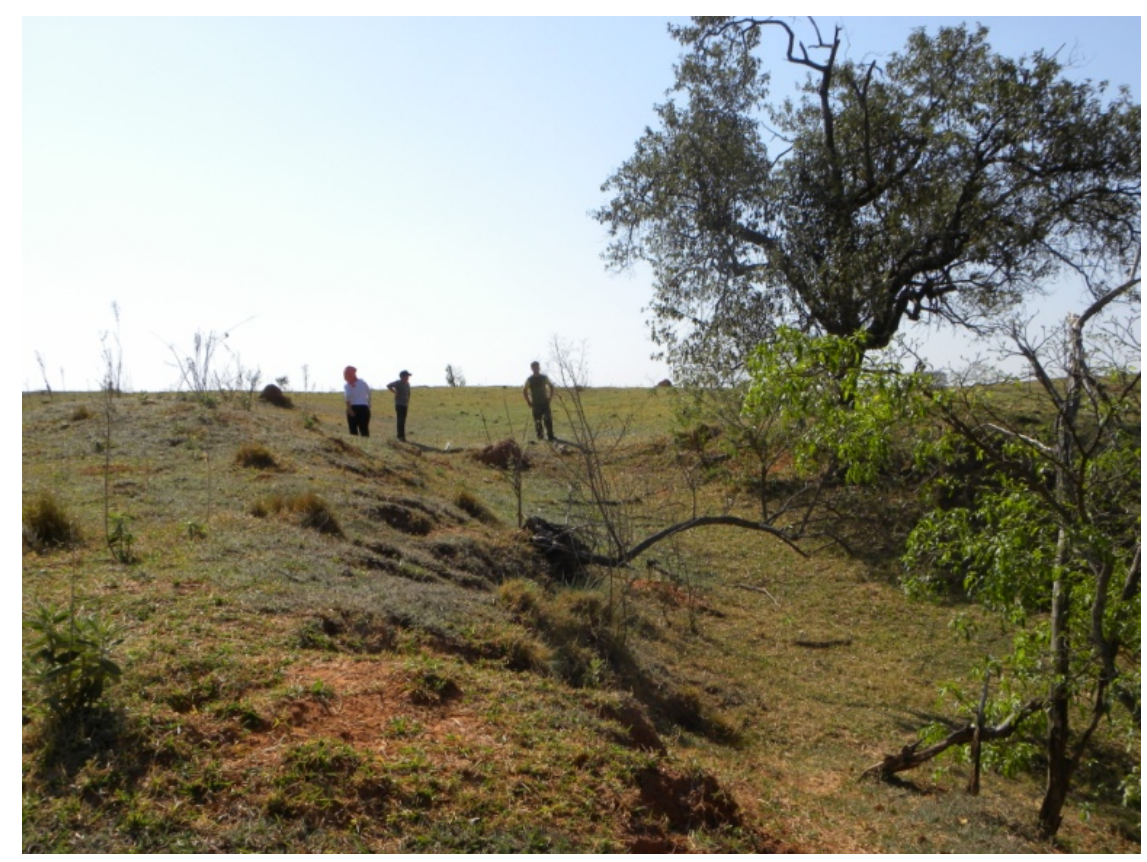

Figura 23: Vista de uma das cabeceiras classificadas como IVa. Nota-se um perfil transversal suave e a ausência de evidências de processos erosivos atuais. 
- A cobertura total ou parcial de algumas feições erosivas ativas depois de 1972 (classe $\mathrm{IVb})$. Ainda que as feições tenham sido enterradas, parece ter ocorrido um processo de reativação em algumas delas, fazendo com que elas reaparecessem, porém, normalmente menores, onde antes se localizava a parte de jusante. Estas feições apresentam mais indícios de processos atuais que as anteriores, predominando o escoamento superficial e raramente resquícios de solapamentos nas cabeceiras; e,

- A mescla entre as dinâmicas anteriores, ou seja, feições subordinadas a estruturas antrópicas e que depois foram enterradas (classe IVc) (Figuras 24 e 25).

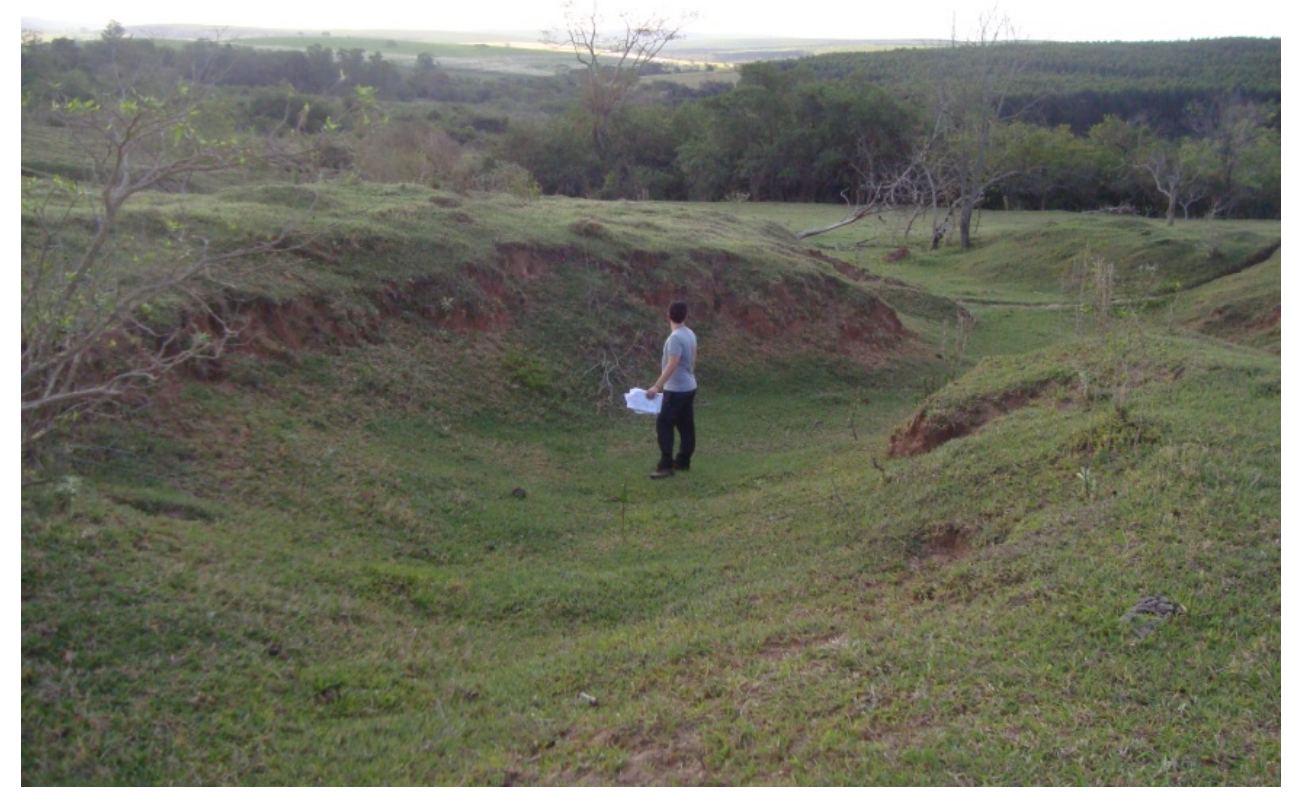

Figura 24: Exemplar de cabeceira classificada como IVc, neste caso mais estabilizada, sendo que a porção enterrada situava-se a montante

As feições subordinadas ao escoamento de caminhos, estradas, etc. têm áreas de contribuição que não correspondem às formas de relevo representadas nas cartas topográficas e identificadas pelo MDT, e as cabeceiras então se situam em posições incomuns, como noses e até grandes divisores de bacia hidrográfica. Tal situação contraria a tendência geral da área de estudo e as descrições de VIEIRA (1978), FURLANI (1980) e STABILE e VIEIRA (2009a) de que a erosão linear predomina nas encostas com curvatura côncava em planta. 


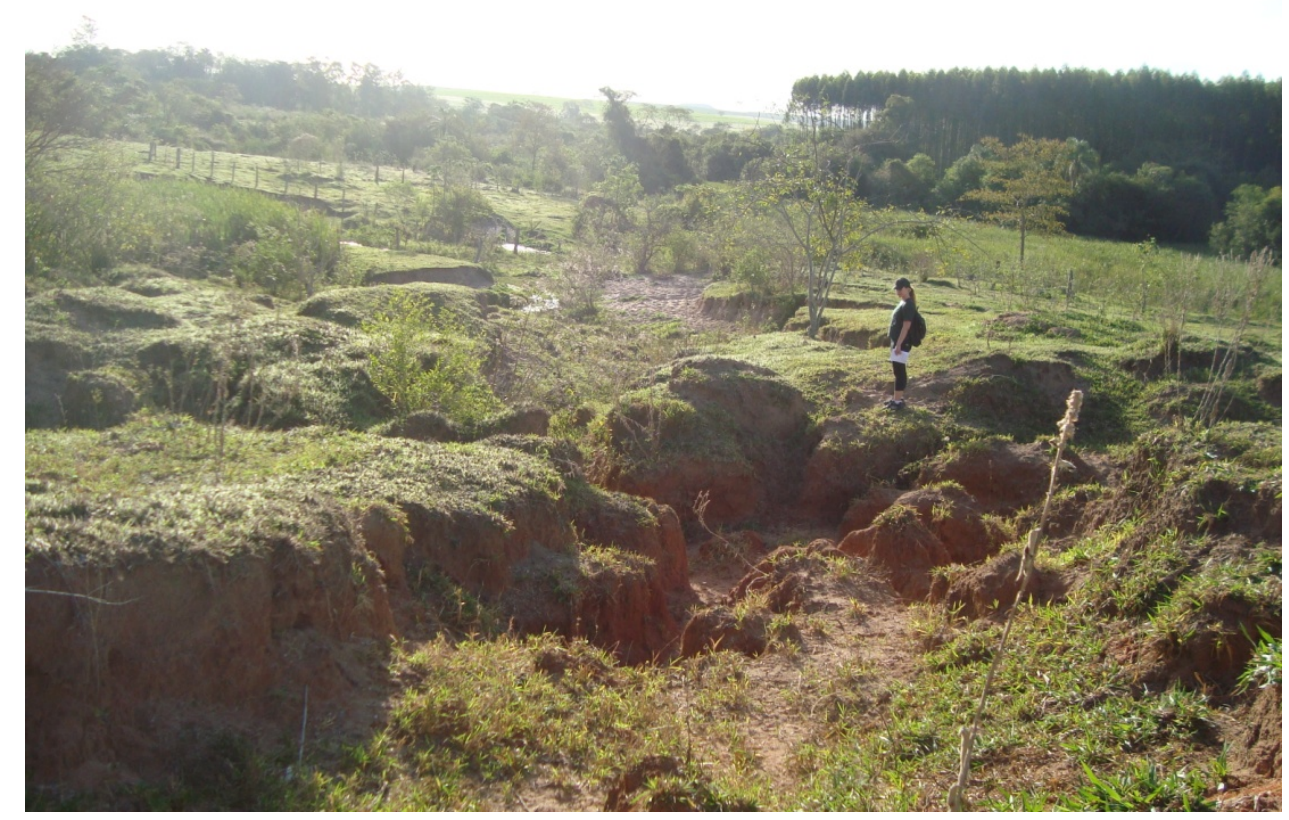

Figura 25: Outra cabeceira classificada como IVc, porém com indícios de escoamento superficial que promoveram a reativação da feição.

Duas feições foram classificadas como canais consolidados (classe III), ou seja, assemelham-se mais a cabeceiras de drenagem. Ambas estão cobertas por vegetação arbóreoarbustiva relativamente densa, têm cabeceiras inclinadas, porém mais suavizadas que as das feições ativas, e sem quaisquer indícios de processos erosivos atuais (Figura 26). É notável que uma dessas cabeceiras em 1972 já tinha tais características, enquanto a outra tratava-se de uma feição erosiva bastante ativa, com solo exposto em todo seu corpo e com depósitos de sedimentos a jusante, ainda que com a posição da cabeceira similar a atual.

As voçorocas de cabeceira (classe I) compõem uma classe de feições relativamente homogêneas, onde predominam feições com forma em planta linear e grande dimensão relativa. Essas feições, que correspondem àquelas que SALOMÃO (1994) denomina como de reativação de cabeceiras de drenagem, iniciam-se junto a cursos d'água de primeira ordem, e desenvolvem-se remontantemente nos hollows, às vezes com mais de um ramo, comumente atingindo a alta encosta. 


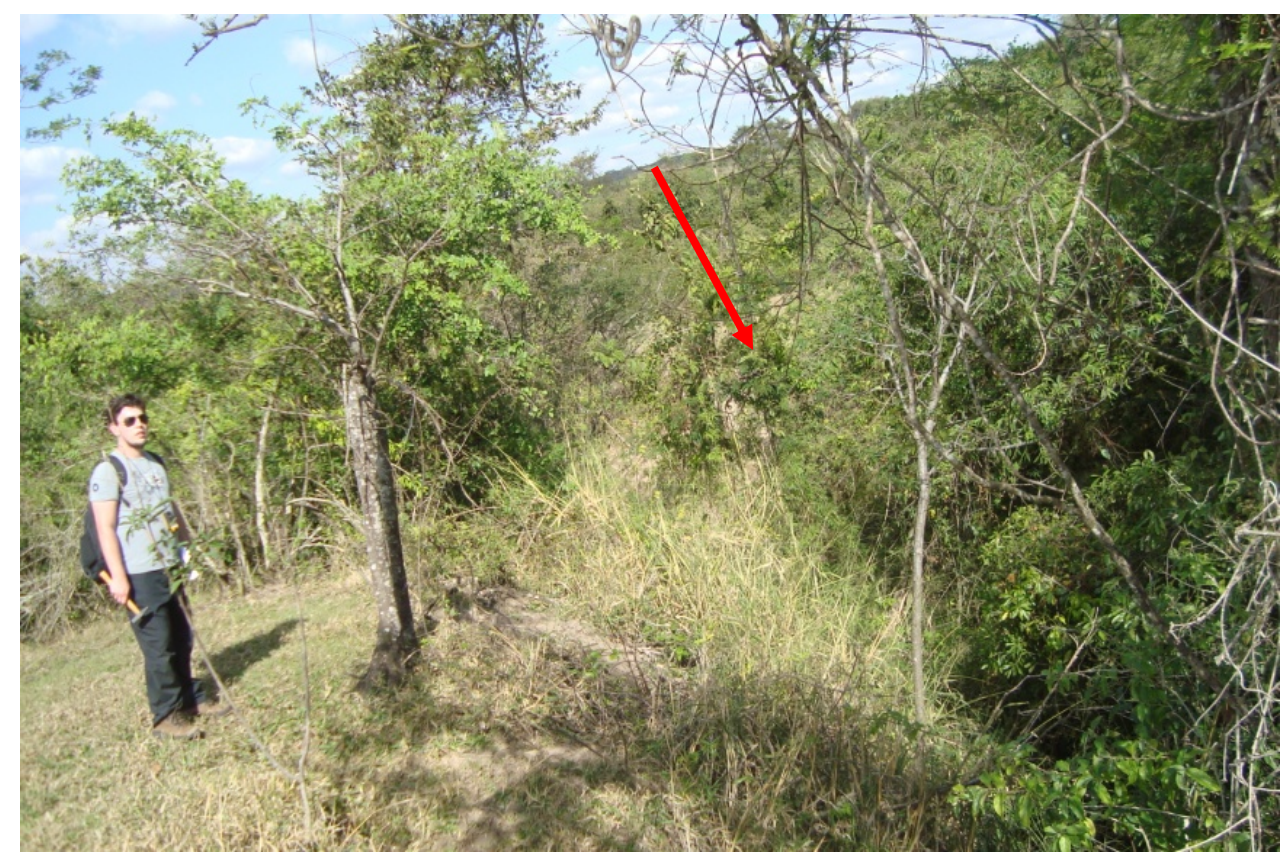

Figura 26: Visão da margem esquerda do canal classificado na categoria III. A vegetação impede a clara visualização do canal.

De maneira geral, foi avaliado que as voçorocas de cabeceira observadas atualmente já existiam em 1972, e que, desde então elas se desenvolveram muito pouco seja em profundidade, largura ou comprimento. Comparando as fotografias aéreas de 1972 com as imagens de satélite atuais, nos casos mais significativos as feições avançaram entre 10 e 20 metros remontantemente em 40 anos, isto é, com média entre 25 e $50 \mathrm{~cm}$ por ano.

As feições da categoria Ic (Figura 27), como já afirmado, foram feições ativas em 1972 que atualmente têm uma condição de forma e até mesmo de processos diversas dos outros subtipos de voçorocas de cabeceira. São feições com limites suaves e cobertas por vegetação gramínea, por vezes dispostas à montante das feições do tipo Ia, e em outros casos dispostas logo a montante do curso d'água a partir do qual se originaram. 


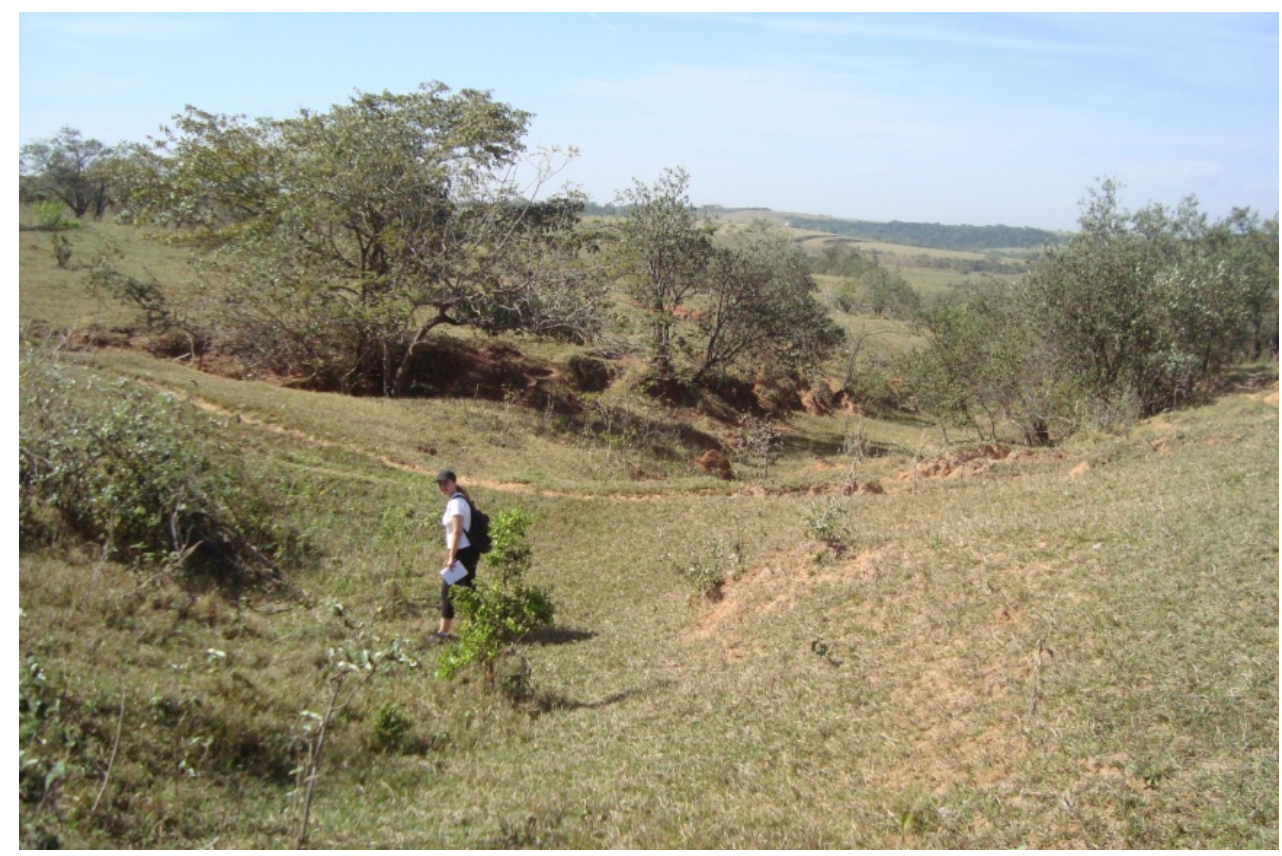

Figura 27: Feição erosiva do tipo Ic. Os limites suaves e a cobertura por vegetação gramínea fazem com que a feição não se destaque na paisagem.

As feições dos tipos Ia e Ib não apresentam diferenças morfológicas perceptíveis nas suas partes mais de jusante. O diferencial entre as duas advém do substrato: enquanto as feições do tipo Ia seguem por encostas com solo espesso até a sua cabeceira, as feições do conjunto $1 \mathrm{~b}$ atingem o substrato rochoso (arenito) quando desenvolvem-se remontantemente. A influência do substrato gera dois tipos de feições distintas nas cabeceiras:

- As cabeceiras Ia são abrutas e com fundo relativamente plano. Os processos atuais abrangem solapamentos relativamente frequentes, piping e, eventualmente, escoamento superficial (Figura 28).

- As cabeceiras Ib são inclinadas, assim como o fundo da feição nos locais mais de montante. Os processos ocorrentes na cabeceira restringem-se a poucas quedas de bloco, e, esporadicamente sinais de escoamento superficial (Figura 29). 
(a)
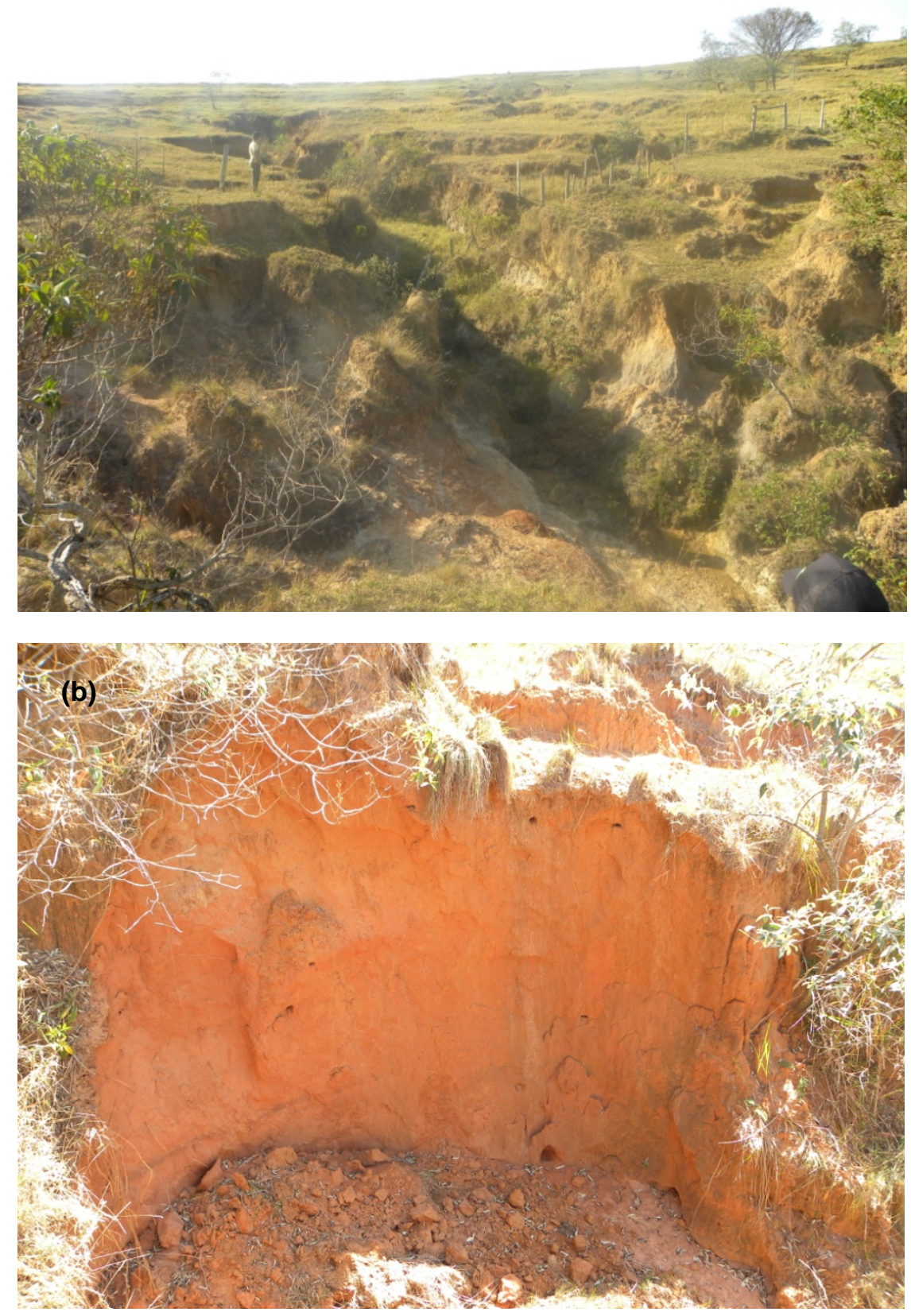

Figura 28: Feição erosiva da classe Ia (a) e detalhe de parte de sua cabeceira (b) 

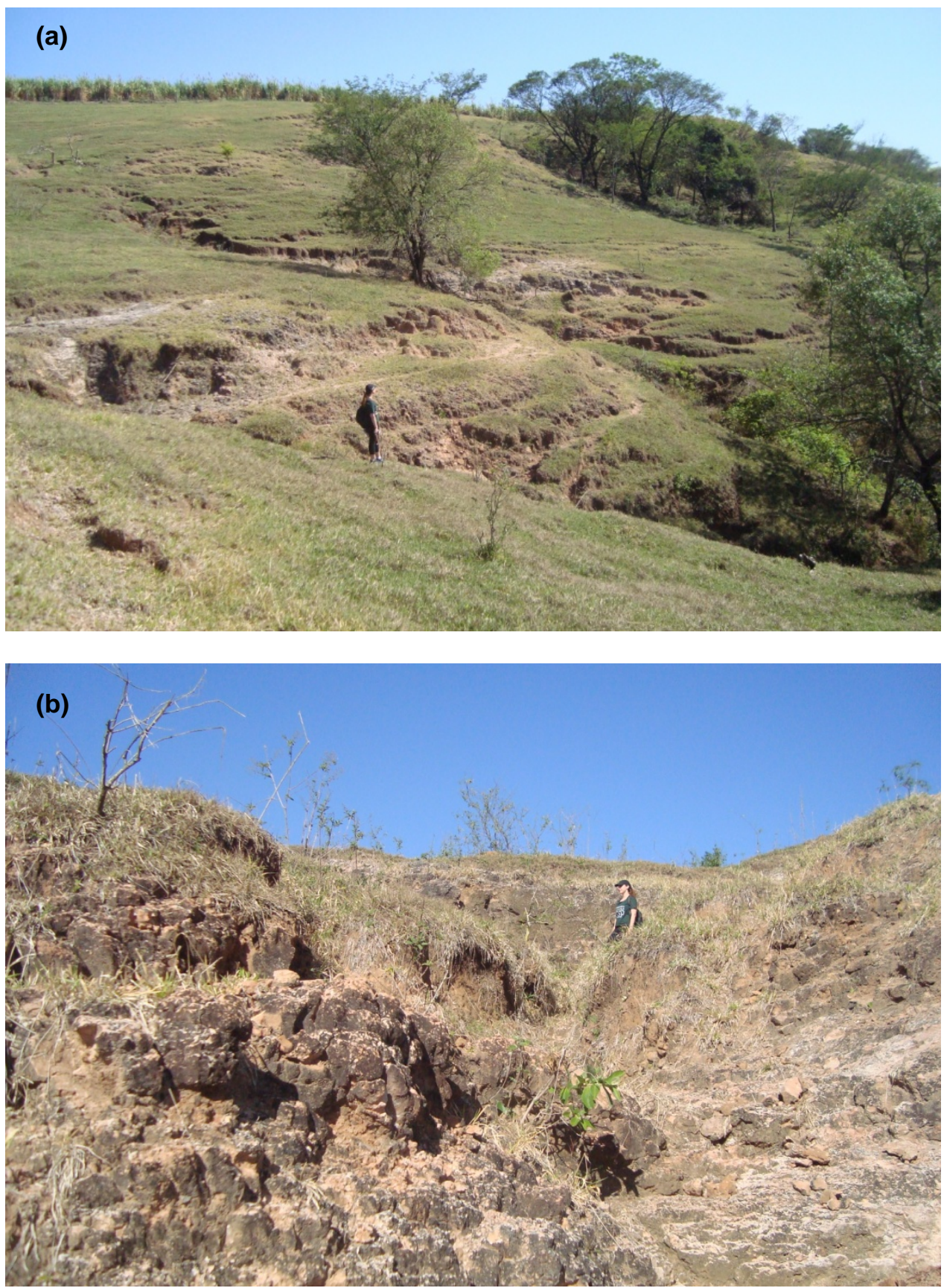

Figura 29: Cabeceira de feição erosiva da classe Ib (a) e detalhe da mesma cabeceira (b). 
$\mathrm{Na}$ quase totalidade das feições erosivas enquadradas nas tipologias Ia e Ib ocorre o afloramento do lençol freático no interior da voçoroca. Entretanto, o fluxo d'água perene aparece somente em um ponto mais a jusante da feição, por vezes mais próxima ao centro, e em outras circunstâncias apenas nas proximidades do curso d'água de origem da feição (Figura 30). Alguns desses pontos de afloramento do lençol são os locais de maior atividade em toda a voçoroca, ocorrendo deslizamentos e solapamento nas paredes laterais, porém eles não interferem, em nenhum dos casos, no recuo das cabeceiras.

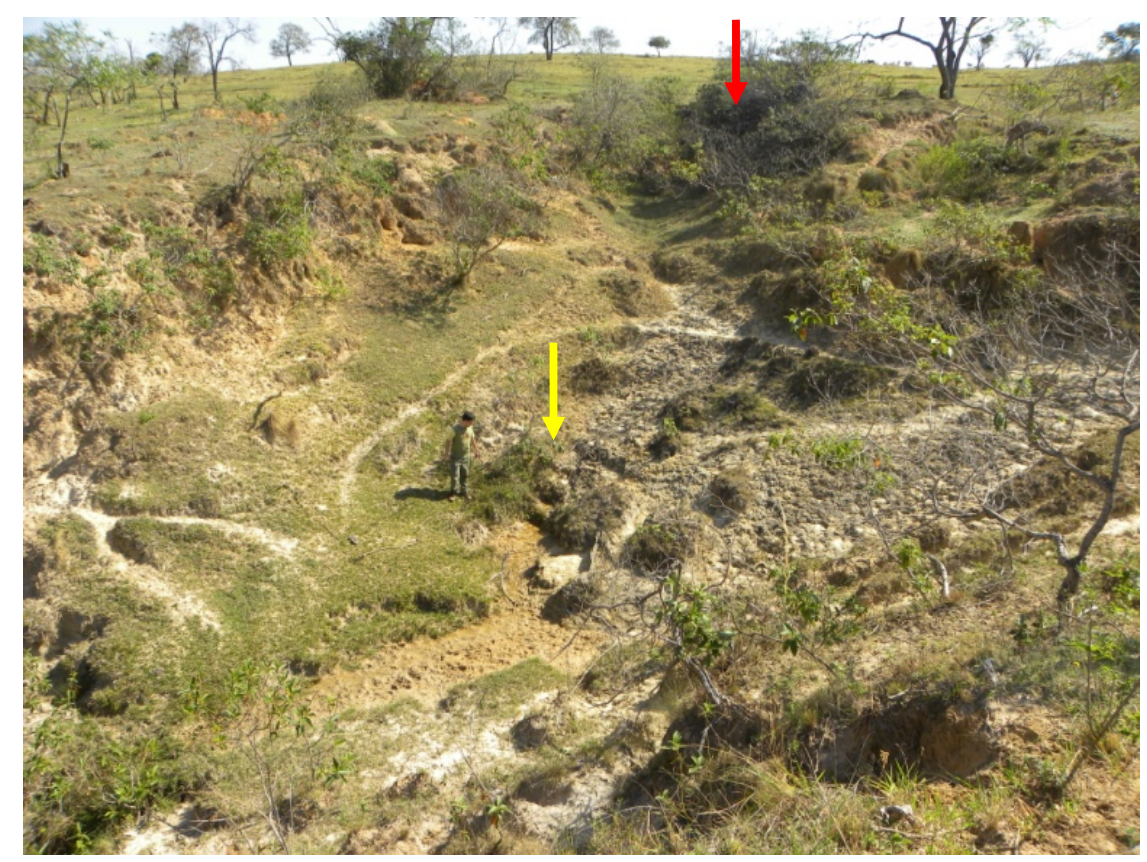

Figura 30: Local de afloramento do lençol freático (seta amarela) em uma das voçorocas da classe Ia. É possível observar que o local está distante da cabeceira da feição (seta vermelha).

Quanto à origem das voçorocas de cabeceira, a teoria de SALOMÃO (1994), de que o aprofundamento e alargamento das calhas dos rios pelo aumento do escoamento superficial deixaram surgências d'água expostas ao longo dos fundos de vale, em barrancos ou na encosta, parece ser apropriada para explicar essa tipologia de erosão. A Figura 31 mostra a calha de um dos rios a jusante de uma voçoroca de cabeceira, onde há um vale profundo, bastante irregular no fundo e com margens instáveis, sujeitas a solapamentos e deslizamentos, característica essa comum aos rios da área de estudo, e que está de acordo com a hipótese de SALOMÃO (1994). 


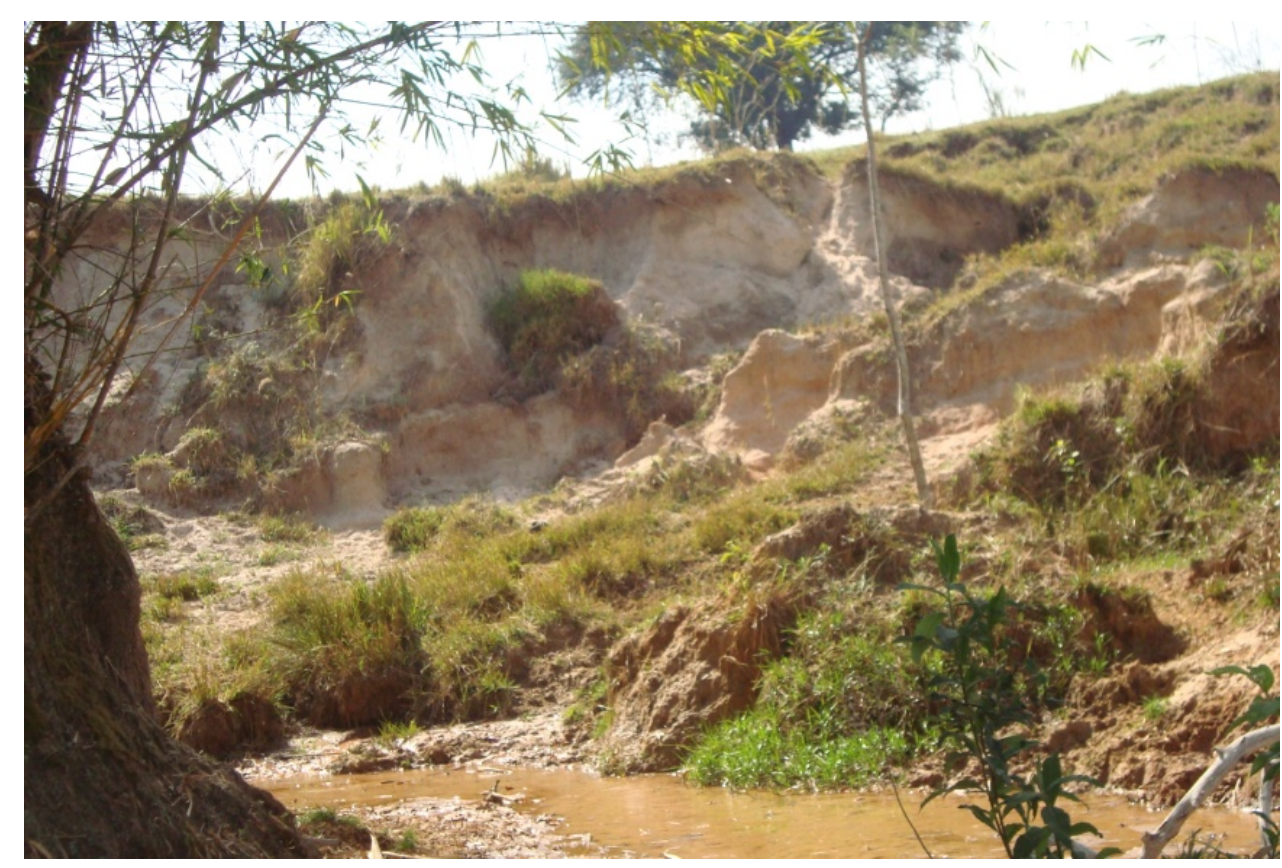

Figura 31: Calha de um dos afluentes do rio Alambari a jusante de uma voçoroca da classe Ia. Nota-se o vale profundo, irregular no fundo e as margens instáveis, sujeitas à solapamentos e deslizamentos.

As voçorocas de encosta (classe II) são feições que predominantemente têm forma em planta grosseiramente circular e têm, em geral, como ponto de início (jusante) áreas adjuntas a rupturas côncavas na baixa encosta (Figura 32), de modo que as áreas mais planas de jusante parecem representar o nível de base dessas voçorocas. O lençol freático raramente aflora nas voçorocas de encosta.

Grande porcentagem das feições da classe II não existia ou estava em estágio inicial em 1972. Apesar disso, poucas dessas voçorocas estão ativas atualmente. Quando existem processos de recuo de cabeceira ativos, sua velocidade de evolução remontante não aparenta ser muito maior que a das voçorocas de cabeceira mais ativas.

Foram estabelecidos três grupos de voçorocas de encosta circulares: circular ativa (IIa), circular inativa (IIb) e circular incipiente (IIc). Além dos canais gramados (classe IIf), existem apenas outras duas cabeceiras de voçorocas de encosta que foram enquadradas em tipologias não circulares: uma cabeceira descrita como linear simples (IId) e outra como linear em patamar (IIe). 


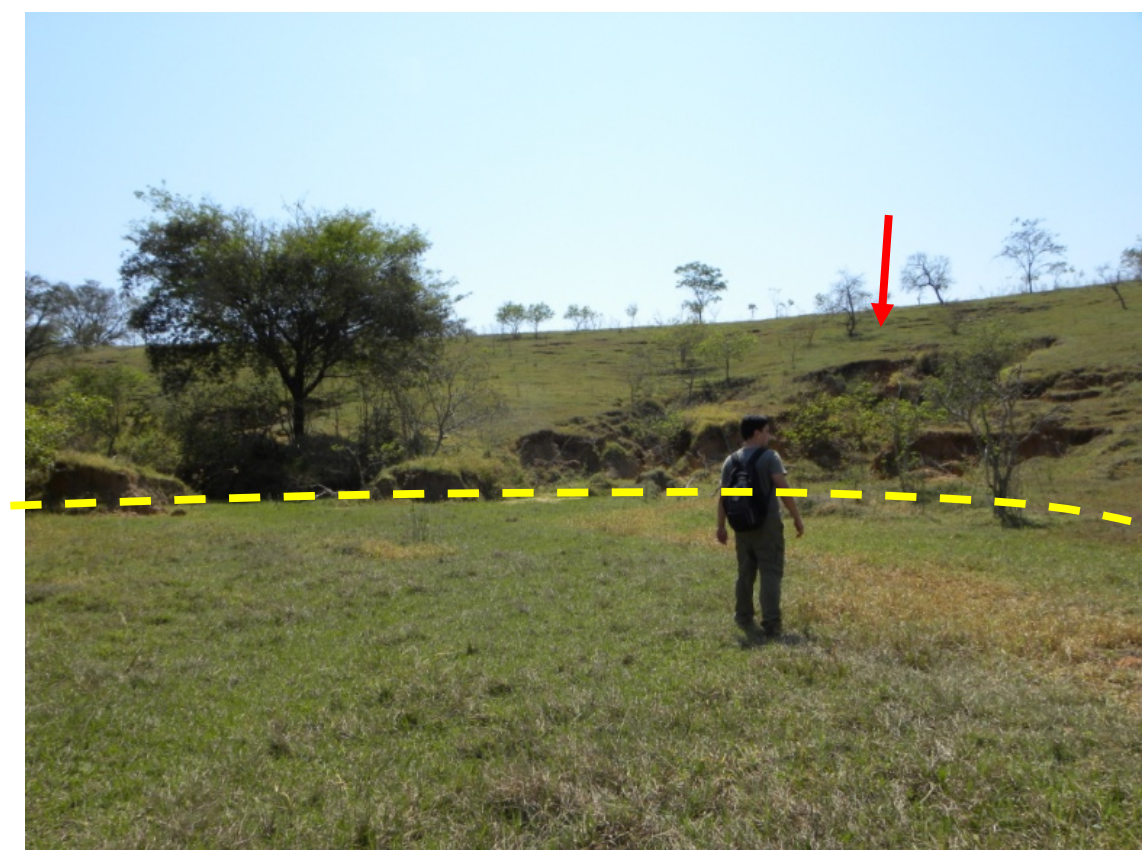

Figura 32: Exemplo de ruptura côncava (linha amarela tracejada) onde normalmente se iniciam as voçorocas de encosta. A seta vermelha indica uma voçoroca de encosta circular.

É interessante notar que a bibliografia referente aos processos erosivos na Bacia Sedimentar do Paraná descreve feições erosivas de encosta diversas das encontradas neste estudo, destacando-se sulcos e ravinamentos com configuração linear e paredes em forma de "V", e algumas voçorocas lineares cujo desenvolvimento é favorecido pela concentração das águas pluviais por estruturas antrópicas. VIEIRA (1978) descreve que no último estágio, as voçorocas de Franca tendem à circularidade, porém, nestes casos a autora está tratando de voçorocas lineares que após evoluírem remontantemente, se ramificam na alta encosta, e depois tendem à circularidade nas cabeceiras. Referências a voçorocas com forma em planta circular são citadas principalmente nos trabalhos realizados em áreas com substrato cristalino, como a pesquisa de SOBREIRA e BACELLAR (1999), em Ouro Preto (MG), que associam feições erosivas circulares à predominância do escoamento subsuperficial na esculturação da feição.

As voçorocas dos tipos IIa e IIb não apresentam diferenças morfométricas quanto a sua forma em planta. Por outro lado, as feições da classe circular ativa (IIa) têm fundo irregular e muitos depósitos de material junto à cabeceira, resultado dos solapamentos generalizados, assim como do piping e, em alguns casos, do escoamento superficial (Figura 33), enquanto que as feições da classe circular inativa (IIb) têm o fundo plano, mais inclinado nas 
proximidades da cabeceira, resultado da estabilização de antigos blocos de solo solapados (Figura 34).

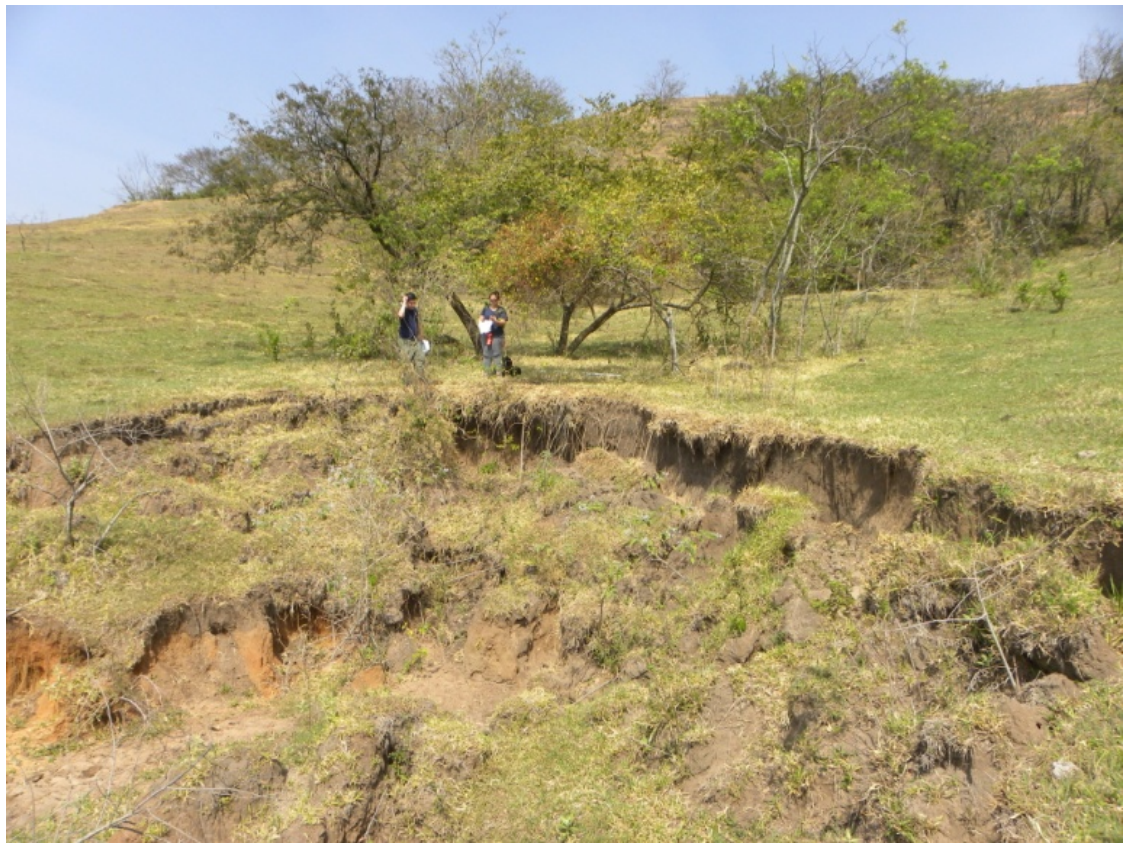

Figura 33: Cabeceira de voçoroca de encosta circular ativa (classe IIa).

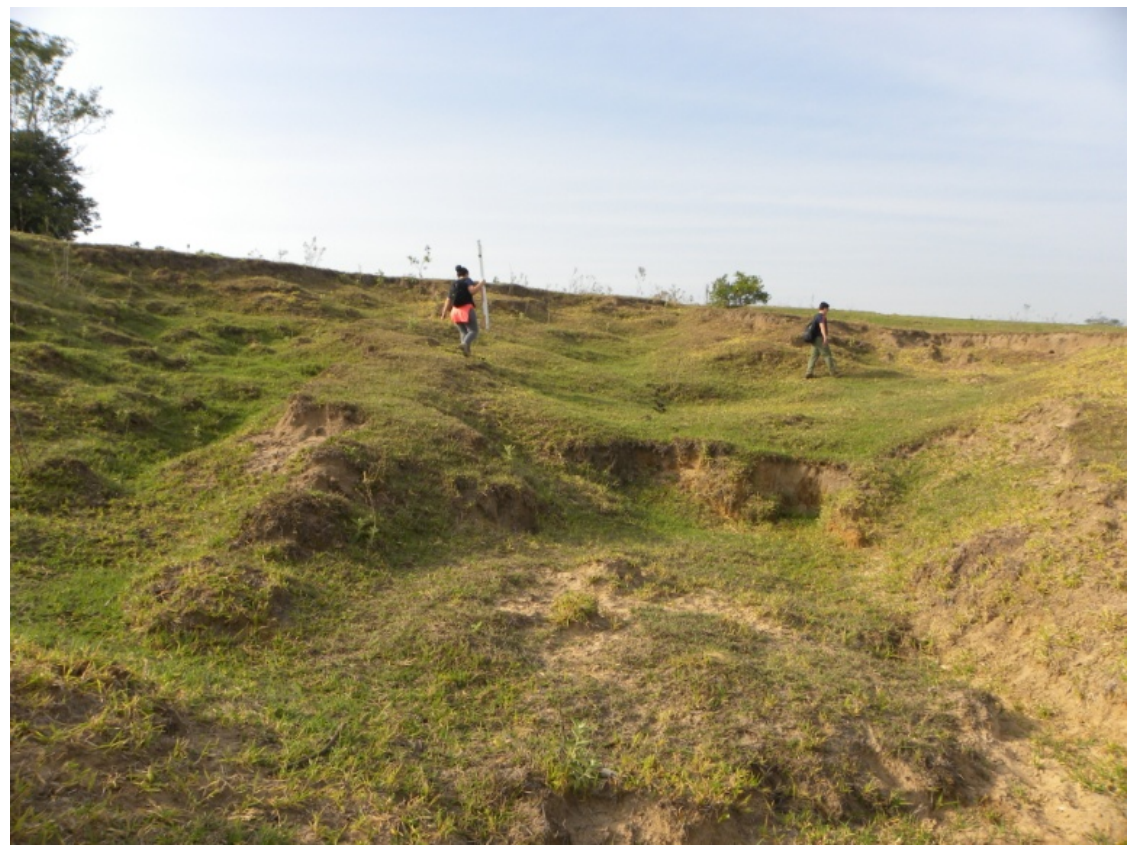

Figura 34: Cabeceira de voçoroca de encosta circular inativa (classe IIb). 
As cabeceiras circulares incipientes têm forma em planta irregular, porém, aparentam uma tendência à circularidade. Mais do que os outros tipos de voçorocas circulares, essas feições não apresentam quaisquer indícios de processos atuais, estando totalmente cobertas por vegetação. Apesar disso, essas feições são relativamente menores.

Envolvida por uma dinâmica similar às voçorocas de cabeceira, a feição IId (linear simples), tem solapamento nas cabeceiras, indícios de piping e marcas de escoamento superficial. Sua morfometria também é similar àquelas, com cabeceira abrupta e fundo plano, porém, a feição tem tamanho menor (Figura 35).

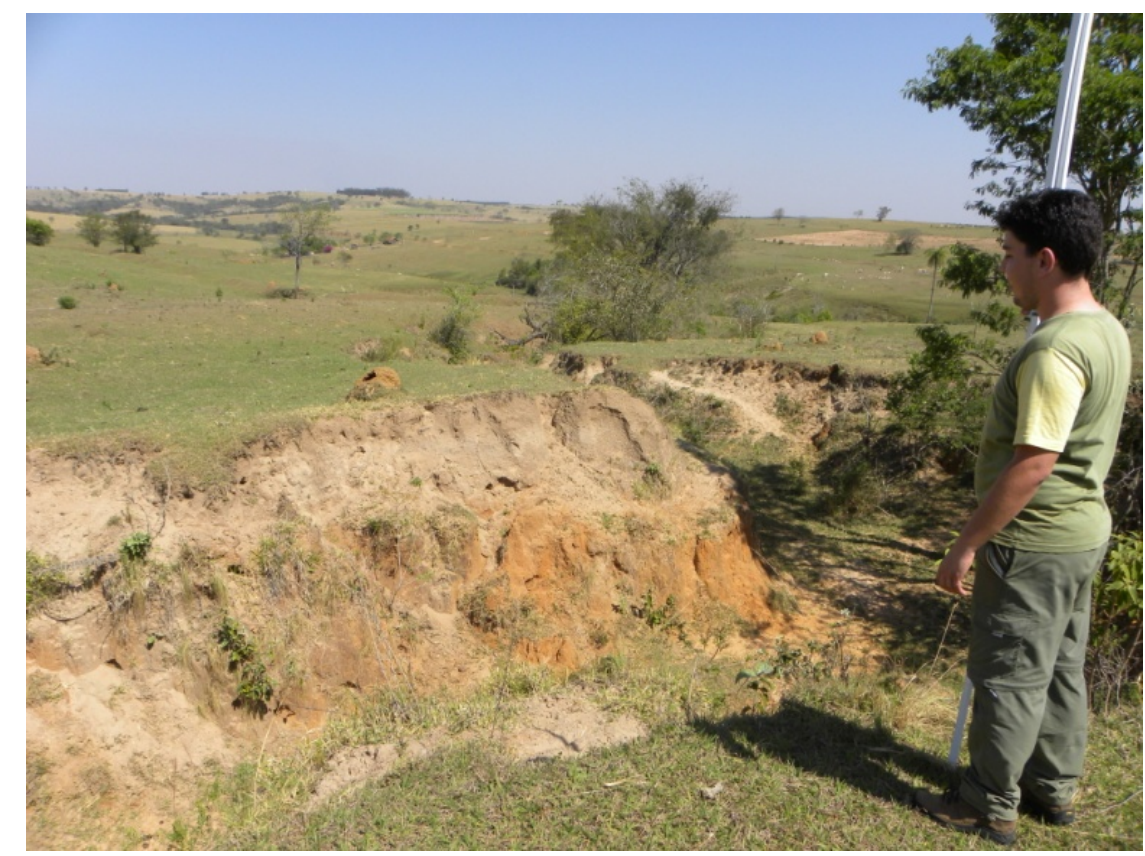

Figura 35 Vista parcial de voçoroca de cabeceira linear simples (classe IId).

A voçoroca de encosta subtipo linear em patamar (classe IIe) é uma feição erosiva bastante singular em relação às demais. Trata-se de uma feição com forma em planta linear, porém, é a única onde as evidências de escoamento superficial são mais significativas que as de outros processos atuais (Figura 36), mesmo que diversas subsidências no terreno do entorno insinuem uma alta importância do piping no desenvolvimento passado da feição . A participação do escoamento superficial na esculturação da voçoroca é indicada pelas alcovas na parte inferior dos patamares, demonstrando a ocorrência de plunge pool, assim como por diversas incisões no leito da feição. Ainda assim, a feição parece estabilizada quanto as suas 
dimensões desde 1972, quando ela aparece totalmente coberta por vegetação de gramíneas na fotografia aérea.
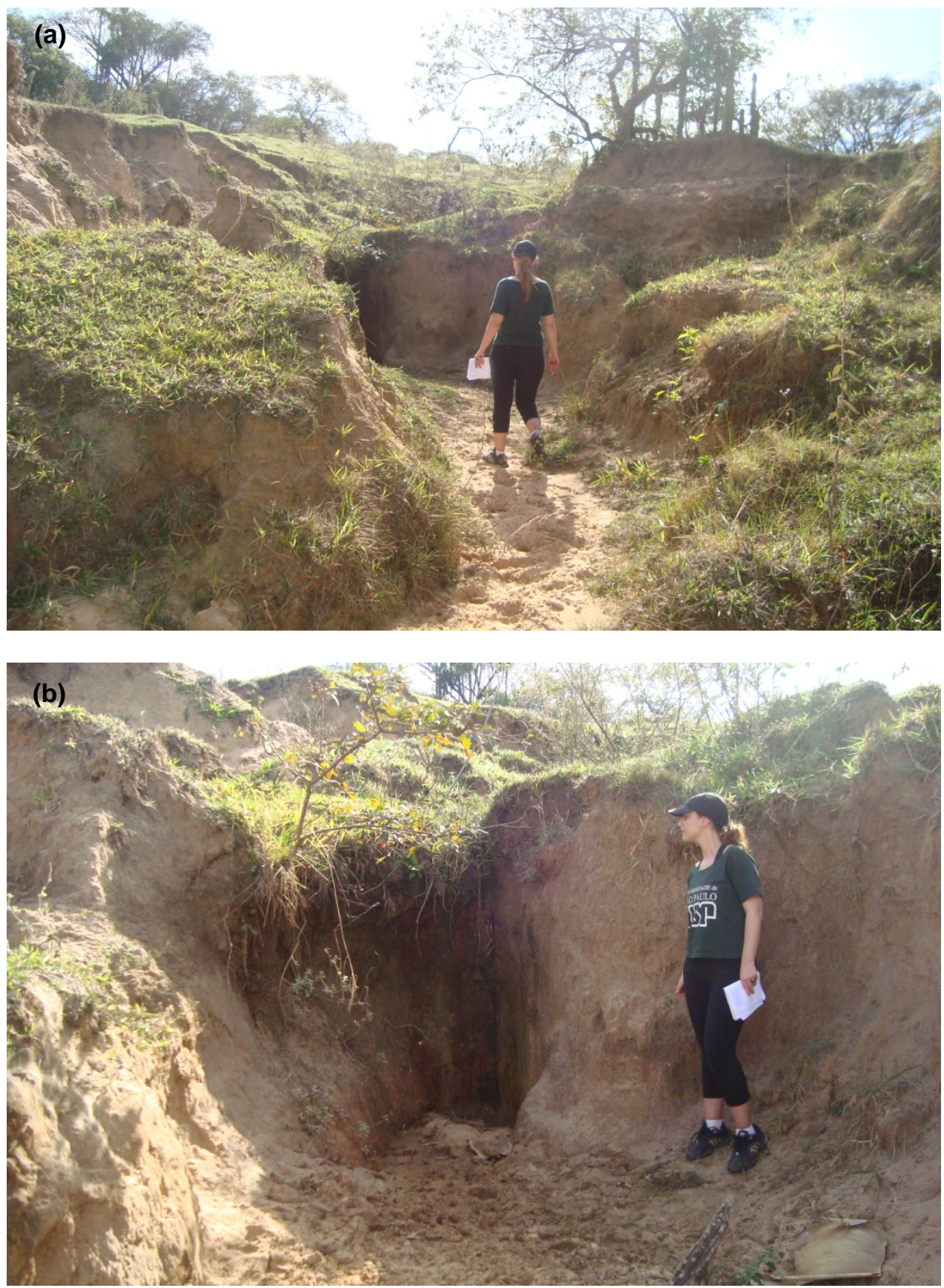

Figura 36: Visão de um dos patamares da voçoroca de encosta subtipo linear em patamar (classe IIe) (a) e detalhe da alcova formada por processo de plunge pool (b). 
Por último, as voçorocas de encosta do tipo canal gramado (classe IIf) referem-se a diversas formas de feições erosivas com fundo coberto por gramíneas, localizadas sobretudo a montante de outras voçorocas de encosta, mas eventualmente também aparecem isoladas (Figura 37). Normalmente estas feições têm forma relativamente linear, mas aparecem também com os contornos aproximadamente dendríticos.

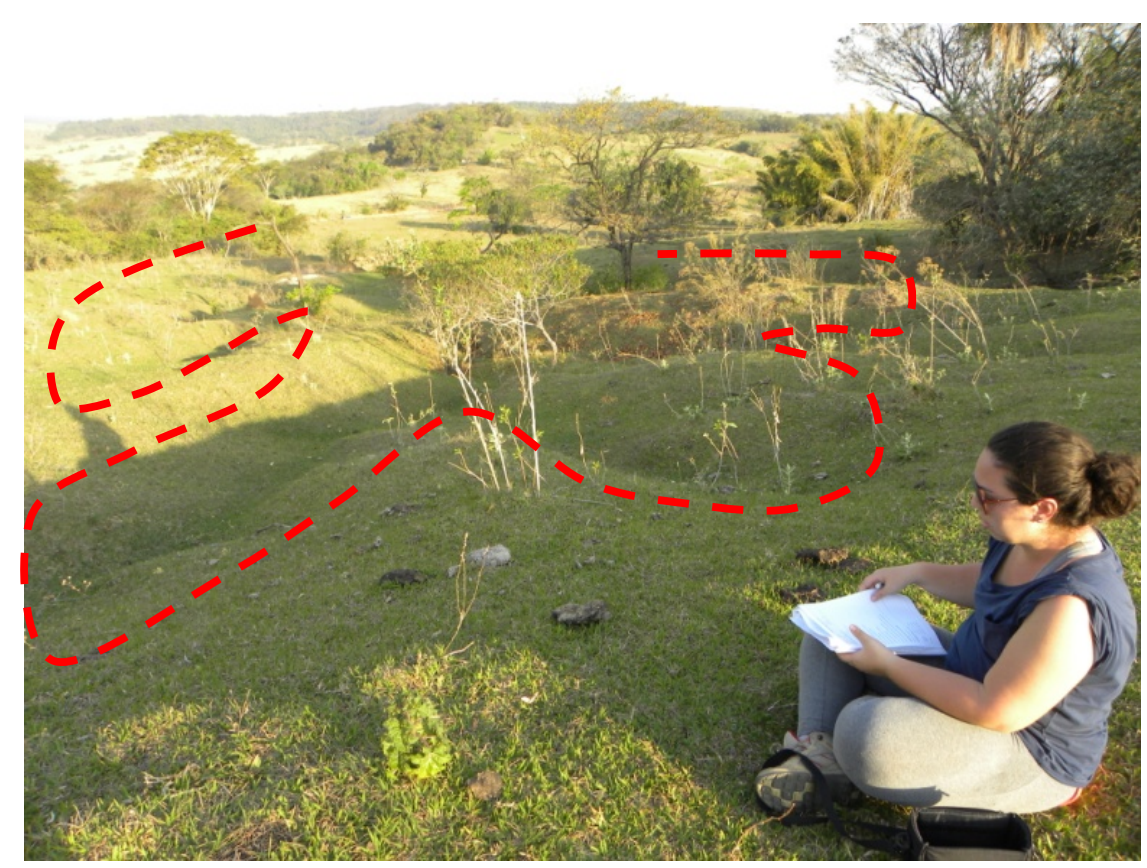

Figura 37: Voçoroca de encosta do tipo canal gramado (classe IIf). A linha tracejada delimita os contornos aproximadamente dendríticos da feição. 


\subsection{Comparação dos Métodos de Mensuração da Declividade e da Área de Contribuição}

A Figura 38 exibe os gráficos com a correlação entre os dados extraídos das diferentes medições de declividade. Foram comparadas as medidas de campo entre si (entre 0 e 1,5m da cabeceira da feição e 0 a $6 \mathrm{~m}$ da cabeceira da feição); as medidas das diversas resoluções de Modelo Digital de Terreno entre si (células de 2x2m, 6x6m e 10x10m); e, as medidas de campo com as medidas dos MDTs.

Conforme a Figura 38a é possível avaliar que os primeiros $6 \mathrm{~m}$ a montante das feições erosivas tendem a ser menos íngremes que os primeiros $1,5 \mathrm{~m}$ a montante. Assim, seguindo a linha de regressão, se uma feição erosiva tem declividade de $0,40 \mathrm{~m} / \mathrm{m}$ no trecho de $1,5 \mathrm{~m}$, sua declividade no segmento de $6 \mathrm{~m}$ tende a ser aproximadamente $0,32 \mathrm{~m} / \mathrm{m}$, com um coeficiente de determinação $\left(\mathrm{R}^{2}\right)$ de 0,75 . Esses resultados demonstram que a extensão do segmento escolhido para a mensuração da declividade influencia nos dados coletados. Ou seja, com exceção de circunstâncias ideais, com encostas retilíneas em perfil e sem quaisquer irregularidades, a seleção do segmento onde será estimada a declividade determinará o posicionamento do limite crítico topográfico projetado a partir da relação entre declividade e área de contribuição.

As mesmas conclusões podem ser feitas a partir da análise da correlação entre os dados gerados pelas diversas resoluções de MDT (Figuras 38d, 38e e 38f), contudo, neste caso as variações são menos intensas. Por exemplo, se a área a montante de uma feição erosiva tiver $0,40 \mathrm{~m} / \mathrm{m}$ de inclinação na célula de $2 \times 2 \mathrm{~m}$, a célula de $6 \times 6 \mathrm{~m}$ a montante da mesma feição tende a ter $0,37 \mathrm{~m} / \mathrm{m}$ de declividade $\left(\mathrm{R}^{2}=0,93\right)$; em outro caso se a área a montante de uma feição erosiva tiver $0,40 \mathrm{~m} / \mathrm{m}$ de inclinação na célula de $6 \times 6 \mathrm{~m}$, a célula de $10 \times 10 \mathrm{~m}$ a montante da mesma feição tende a ter também $0,37 \mathrm{~m} / \mathrm{m}$ de declividade $\left(\mathrm{R}^{2}=0,92\right)$. A Figura 39 ilustra os produtos (classes de declividade) de distintas resoluções de MDT em um trecho da área estudada.

Observa-se que, mesmo utilizando o referencial teórico de MONTGOMERY e DIETRICH (1988), de que os processos erosivos que controlam as cabeceiras dos canais são muito influenciados pela declividade local, há que se definir qual é a declividade local. Consequentemente, quando PATTON e SCHUMM (1975) mensuram a declividade em cartas topográficas entre as duas curvas de nível mais próximas da cabeceira do canal, DIETRICH et al. (1993) extraem a declividade de unidades elementares definidas pelo Modelo Digital de Terreno TOPOG, e VANDEKERCKHOVE et al. (2000), aferem a declividade local em campo a até $3 \mathrm{~m}$ da cabeceira do canal, mesmo que estejam seguindo um mesmo referencial 
teórico, estão adotando procedimentos que interferem diretamente, em maior ou menor grau, nas relações entre declividade e área de contribuição estabelecidas.

A comparação entre as declividades mensuradas em campo e as obtidas pelo MDT (Figuras $38 \mathrm{~b}$ e $38 \mathrm{c}$ ) revela que elas têm uma correlação bastante baixa. Tal fato pode ser explicado pelo nível de detalhamento das cartas topográficas utilizadas para a geração dos MDTs, isto é, a equidistância de $5 \mathrm{~m}$ das cartas topográficas não é suficiente para incorporar as pequenas variações no relevo local a montante das feições erosivas. Considerando a média de declividade de $0,146 \mathrm{~m} / \mathrm{m}$ na cabeceira das feições erosivas, seria necessário mensurar a declividade em um segmento de aproximadamente 34 metros para atingir os 5 metros de amplitude altimétrica entre curvas de nível. 

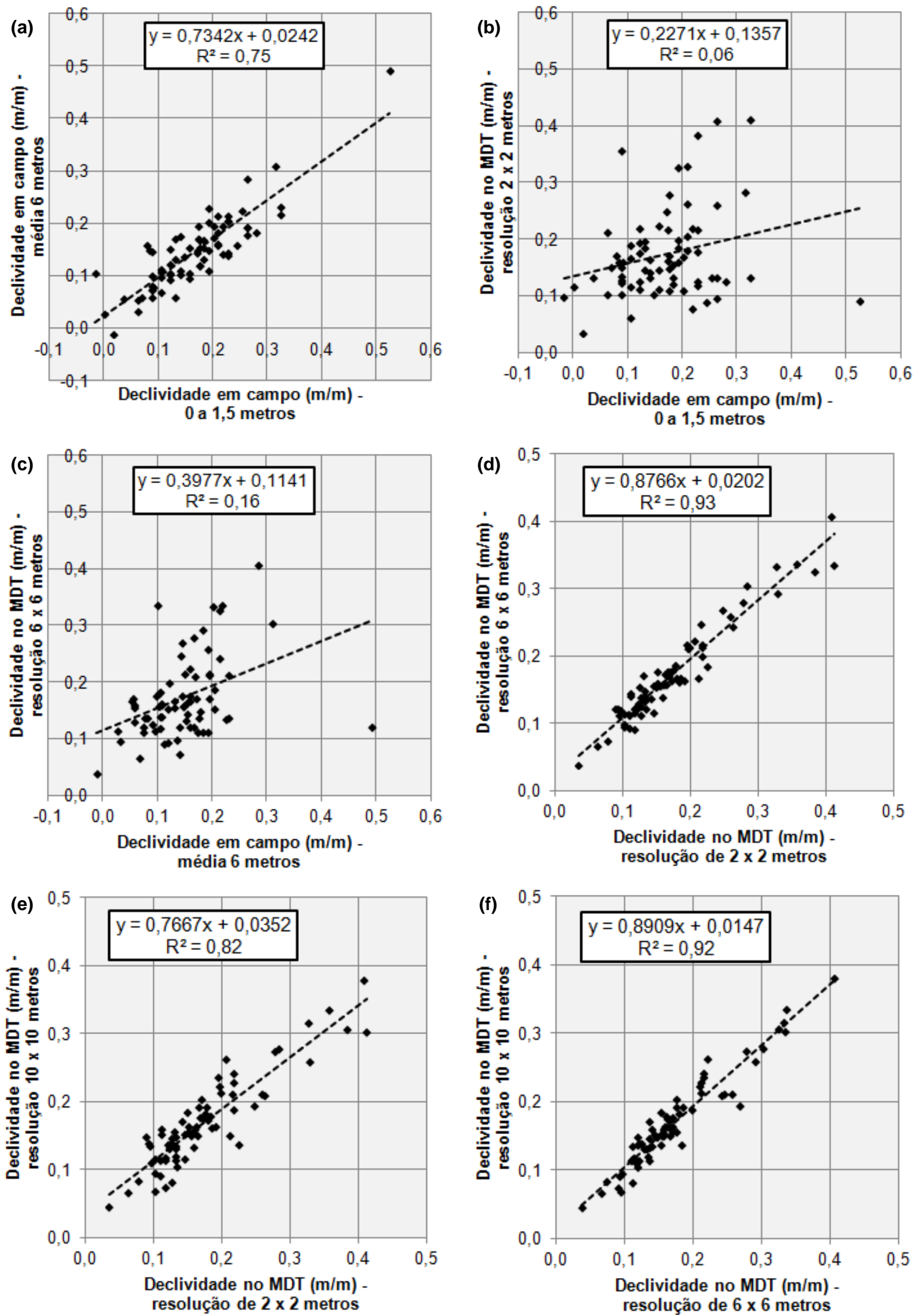

Figura 38: Gráficos da correlação entre as diversas medidas de declividade. A linha tracejada representa a linha de regressão dos dados. Priorizou-se a comparação entre as diferentes medidas de campo, entre as diferentes resoluções de MDT e entre as medidas de campo e o MDT. 

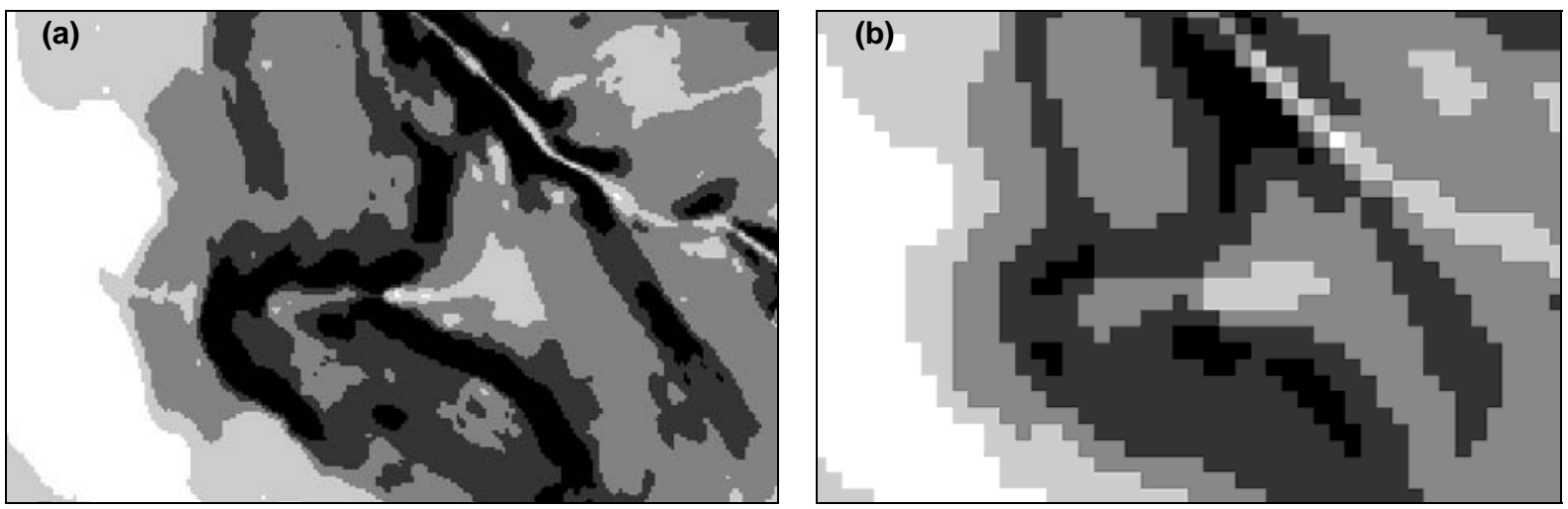

Figura 39 Comparação entre as classes de declividade geradas pelo MDT com resolução de 2x2m (a) e pelo MDT com resolução de 10x10m (b). Escala aproximada: 1:4.000.

Deve-se considerar ainda que as áreas a montante das feições erosivas estudadas têm um relevo muito irregular, com muitas proeminências e depressões, que incluem desde trilhas de pisoteio de gado e sistemas de cordões de nível arrasados a áreas reprimidas por piping. (Figura 40). Isso significa que as próprias mensurações de campo podem sofrer interferência de inúmeras situações que resultam em expressivas alterações dos resultados finais de declividade a montante das feições. Além disso, em algumas vezes não foi fácil identificar a linha de maior declive a montante da feição e a direção da medição também pode alterar os resultados.

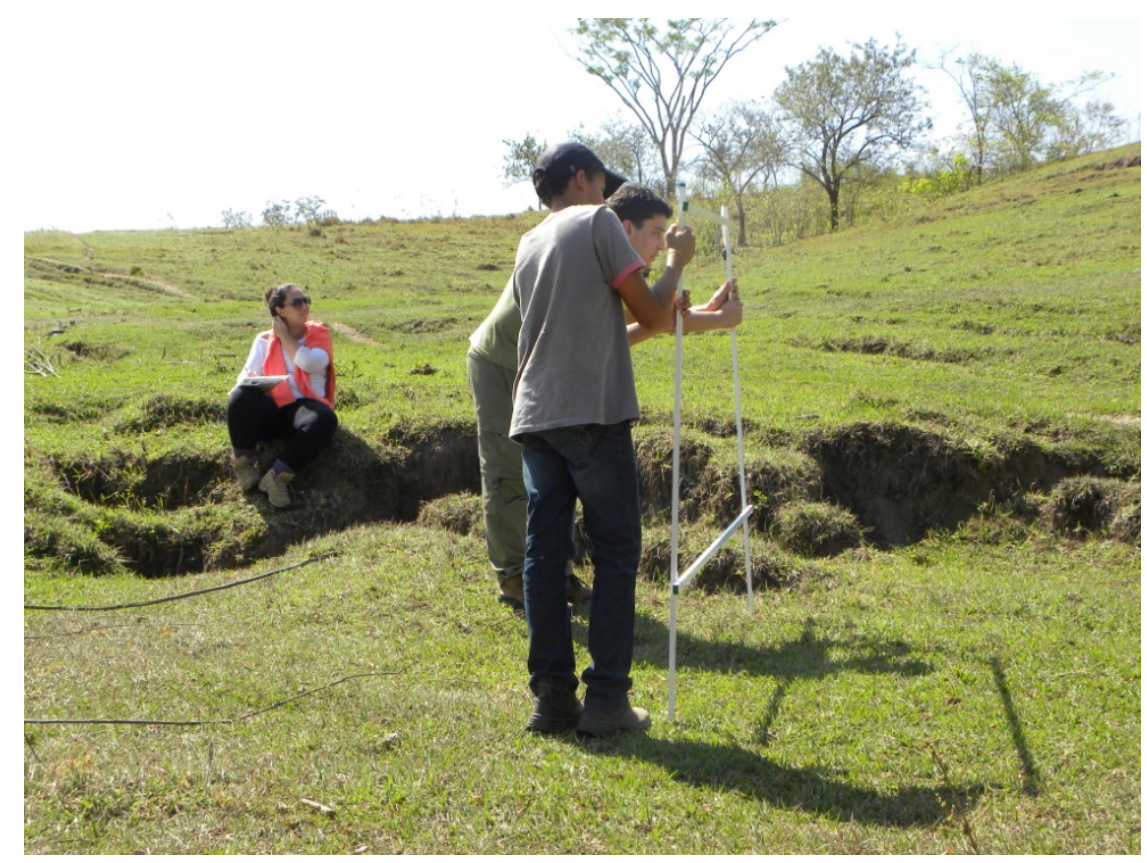

Figura 40: Exemplo de irregularidade no relevo que gera distorções nos dados de declividade mensurados em campo com o uso do pantômetro. 
A ponderação dos resultados descritos motivou a seleção dos dados de declividade gerados a partir do Modelo Digital de Terreno com resolução de 10x10m para a avaliação dos limites críticos topográficos. Esses dados representam ao menos uma média da declividade local a montante das feições erosivas, sem sofrer a interferência de pequenas irregularidades no relevo e sem extrapolar as informações disponíveis nas cartas topográficas.

A Figura 41 expõe os gráficos da correlação entre os dados extraídos das diferentes medições de área de contribuição. Neste caso, foram confrontadas as medidas das diversas resoluções de MDT (células de 2×2 metros, 6x6 metros e 10x10 metros).

Analisando a correlação entre os dados de áreas de contribuição gerados por diferentes resoluções de MDT (Figuras 41a, 41c e 41e), é perceptível que a escolha do tamanho da célula afeta significativamente os resultados de área de contribuição, em uma escala muito maior do que interfere nos dados de declividade. Todavia, as máximas diferenças entre os valores são visualizadas nas áreas de contribuição maiores, sobretudo acima de $500 \mathrm{~m}^{2}$.

Restringindo a análise aos dados para as áreas de contribuição menores que $500 \mathrm{~m}^{2}$ (Figuras 41b, 41d e 41f) é evidenciada uma correlação mais forte, até similar às encontradas para os dados de declividade quando considera-se as áreas de contribuição geradas pelos MDTs com resolução de 6x6m e 10x10m.

É provável que as expressivas diferenças encontradas para as áreas de contribuição maiores estejam relacionadas a sua localização em hollows, que frequentemente estão em contato direto com noses e outros locais com áreas de contribuição baixas, refletindo em grande número de diferenças bruscas de área de contribuição entre células contíguas, em especial quando os tamanhos de célula são menores (Figura 42). Deste modo, quando a resolução do MDT é alterada, o posicionamento exato de cada célula pode muitas vezes refletir em áreas de contribuição bastante diversas. Por outro lado, o padrão de distribuição das células de declividade mostra mudanças mais suaves, de modo que dificilmente uma área de declividade muito baixa passa abruptamente a uma declividade muito alta, reduzindo o erro inerente à resolução do MDT. Igualmente à declividade, foram selecionados os dados de área de contribuição gerados a partir do Modelo Digital de Terreno com resolução de 10x10m para a avaliação dos limites críticos topográficos. 
(a)

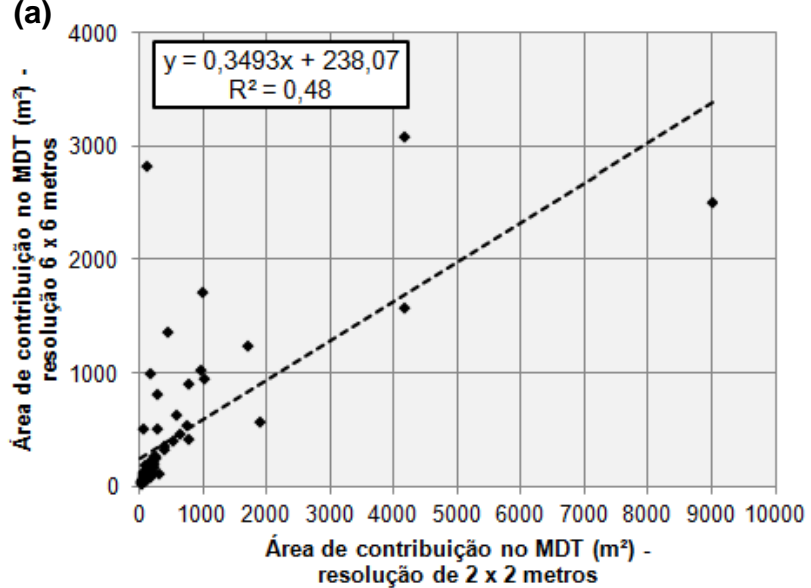

(c) 4000

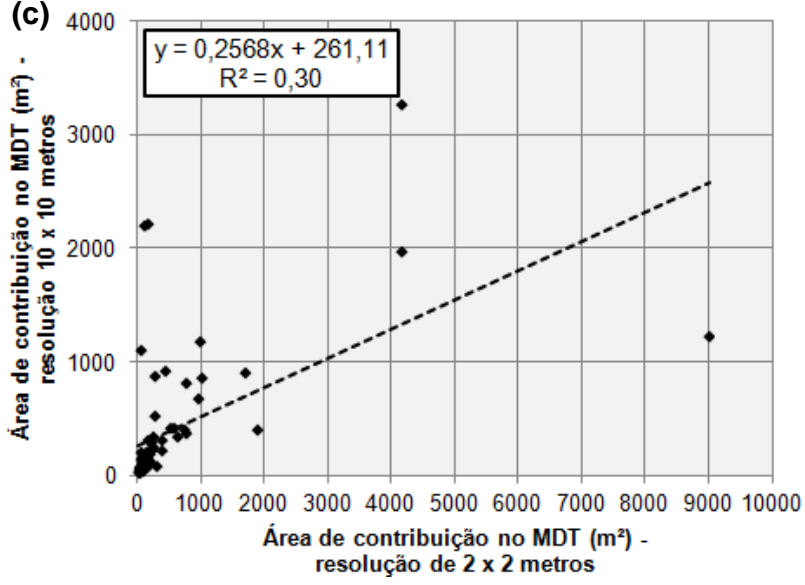

(e)

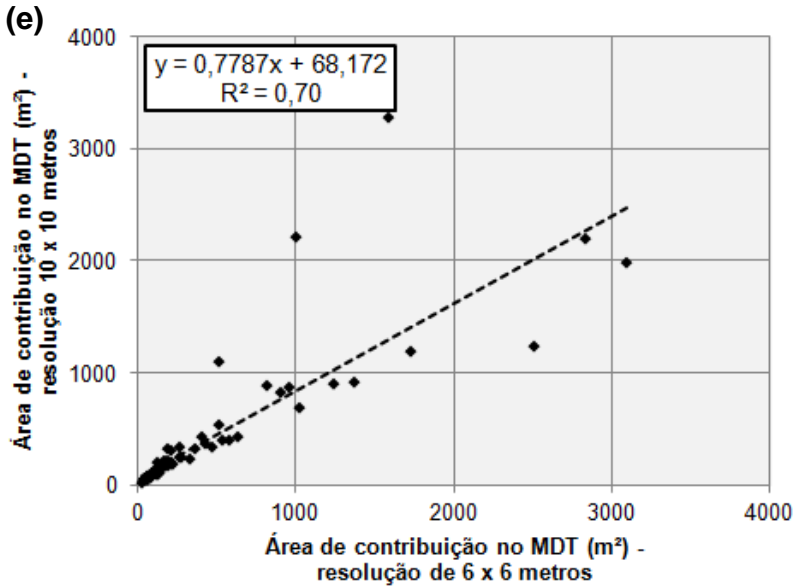

(b)

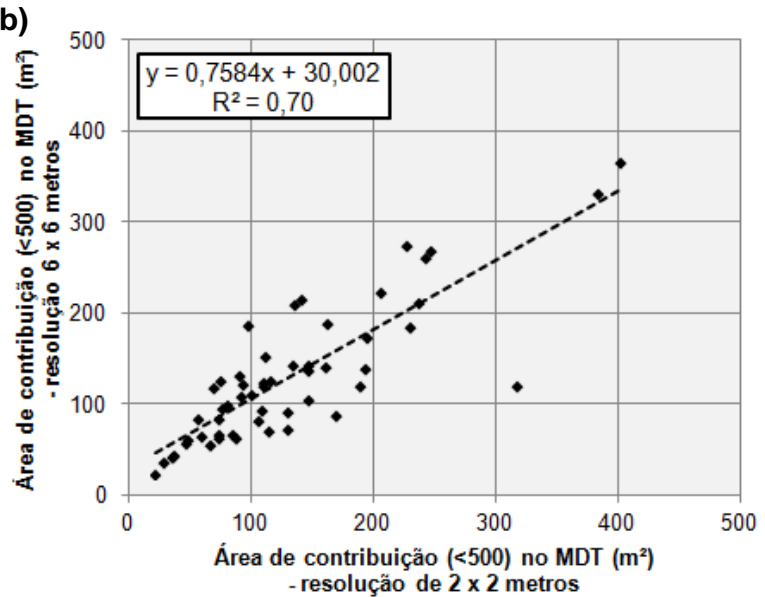

(d)

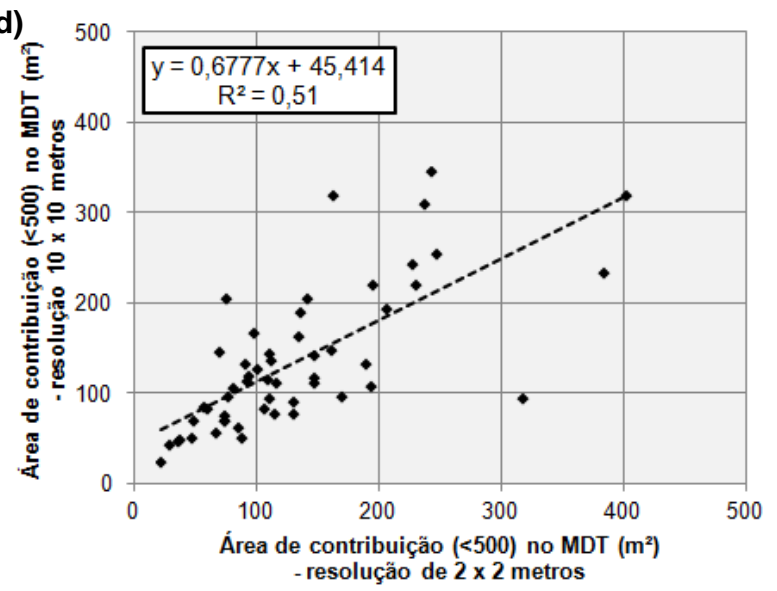

(f)

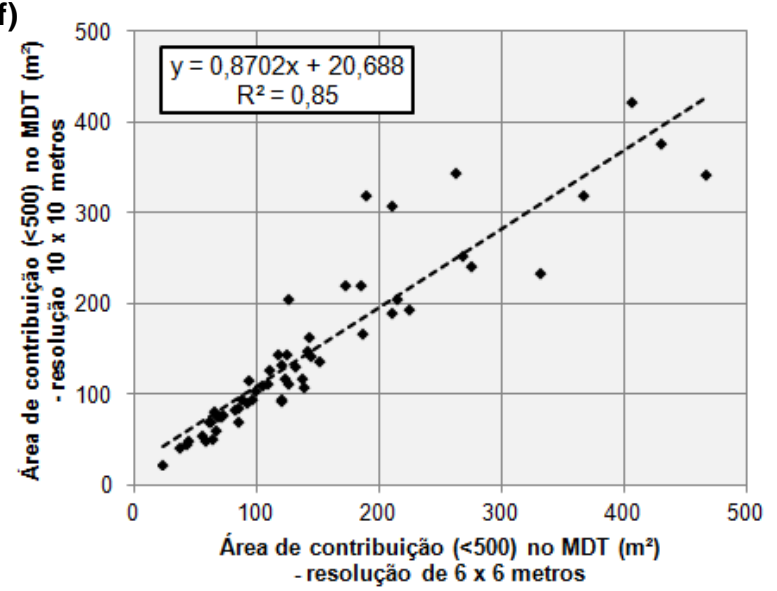

Figura 41: Gráficos da correlação entre as diversas medidas de área de contribuição. A linha tracejada representa a linha de regressão dos dados. Priorizou-se a comparação entre as diferentes resoluções de MDT. Os gráficos da direita foram construídos com os dados da mesma resolução de MDT que os respectivos gráficos da esquerda, porém, apenas com as áreas de contribuição menores que $500 \mathrm{~m}^{2}$. 

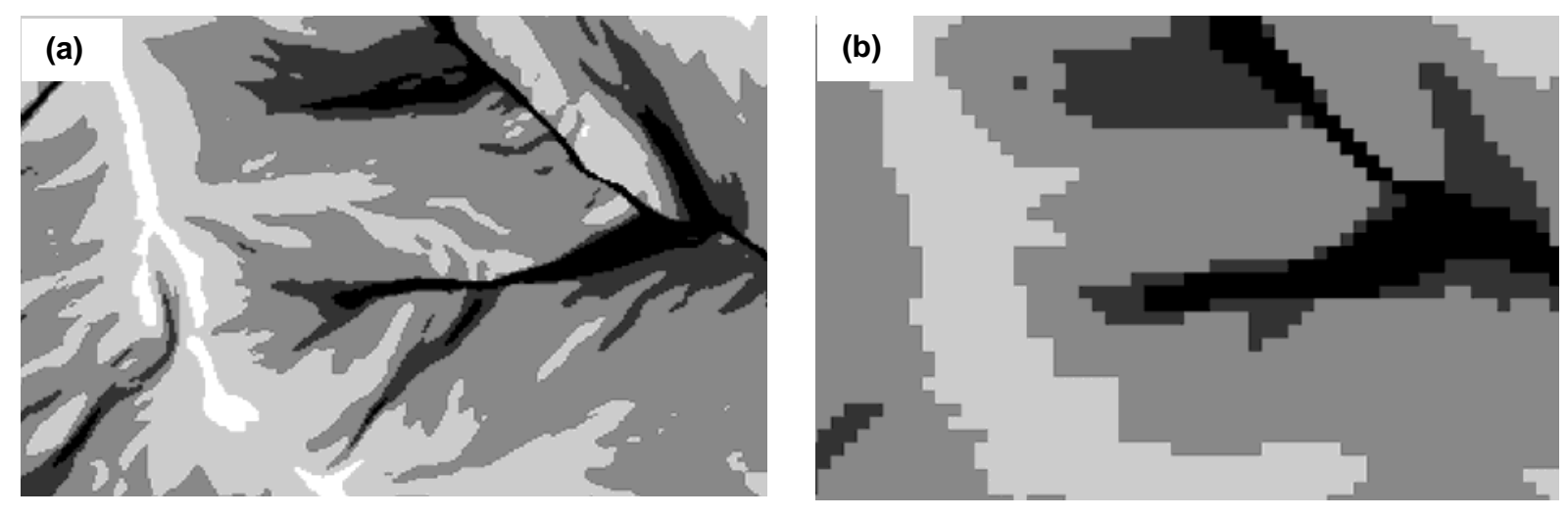

Figura 42: Comparação entre as classes de área de contribuição geradas pelo MDT com resolução de 2x2m (a) e pelo MDT com resolução de 10x10m (b). Escala aproximada: 1:4.000.

\subsection{Limites Críticos Topográficos: Aspectos Gerais}

A Figura 43 apresenta a relação entre declividade (S) e área de contribuição (A) para as feições erosivas estudadas. Os dados foram divididos entre as feições erosivas da classe IV (com condicionamento antrópico) e as demais feições onde não foram registradas evidências de condicionamento antrópico que influenciasse diretamente na posição da cabeceira (classes I, II e III $)^{4}$. Pode-se visualizar uma tendência negativa, ou seja, a diminuição de S com o aumento de A. Em geral, as associações entre S e A com essa configuração (expoente $b$ negativo) têm sido descritas como vinculadas a canais formados a partir de processos de escoamento superficial Hortoniano ou escorregamentos translacionais rasos (MONTGOMERY e FOUFOULA-GEORGIOU, 1993; MONTGOMERY e DIETRICH, 1994; PROSSER e ABERNETHY, 1996).

MONTGOMERY e DIETRICH (1994) explicam tal vínculo com base em modelos matemáticos em bases físicas, demonstrando, a partir das equações específicas a cada processo, qual a relação entre S e A esperada. No caso do escoamento superficial Hortoniano, a área de contribuição crítica necessária para a formação de um canal é descrita pela Equação 8:

\footnotetext{
${ }^{4}$ As unidades de S (m/m) e A (ha) foram escolhidas com base na apresentação dos dados pela bibliografia, a fim de facilitar a comparação dos resultados.
} 


$$
a_{c r}=\frac{2 \times \tau_{c r}{ }^{3}}{(R-I) \times k \times v \times \mathrm{p}_{w}{ }^{3 \times} \times g^{2} \times S^{2}}
$$

onde: $a_{c r}$ é a área de contribuição crítica necessária para ocorrer erosão por fluxo superficial Hortoniano; $\tau_{\mathrm{cr}}$ é a tensão de cisalhamento crítica; $R$ é a intensidade da chuva em condições de steady state; I é a capacidade de infiltração; $k$ é um coeficiente adimensional de rugosidade da superfície; $v$ é a viscosidade; $p_{w}$ é densidade da água; $g$ é aceleração da gravidade; e, $S$ é a declividade.

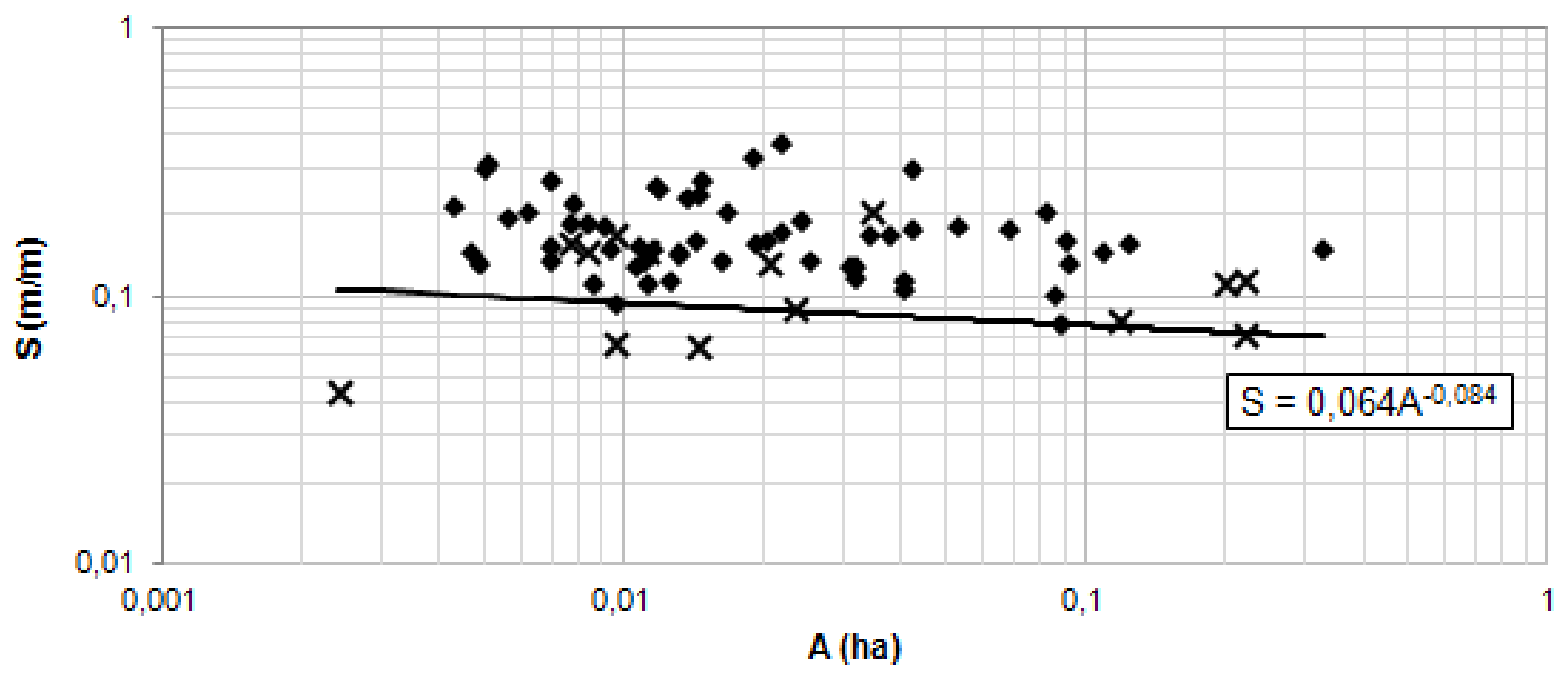

x Feições erosivas com condicionamento antrópico

- Feições erosivas sem condicionamento antrópico

—Limite crítico das feições erosivas sem condicionamento antrópico

Figura 43: Relação entre área de contribuição e declividade para feições erosivas com condicionamento antrópico (classe IV) e sem condicionamento antrópico (classes I, II e III). Também está indicado no gráfico o limite crítico topográfico para as feições erosivas sem condicionamento antrópico. 
MONTGOMERY e DIETRICH (1994) propõem que as cabeceiras de canais abruptas, resultantes da seepage erosion (erosão resultante do escoamento subsuperficial pelas águas de exfiltração), podem ser modeladas como dependentes da saturação do solo. A área de contribuição crítica para a saturação do solo e para a consequente formação de canais nesses casos é obtida conforme a Equação 9, ou seja, a relação entre S e A nesses casos é positiva (aumento de A com o aumento de S).

$$
A_{c r}=\frac{T \times S}{R}
$$

onde: $A_{c r}$ é a área de contribuição crítica para a saturação do solo; $T$ é a transmissividade do solo; $S$ é a declividade; e, $R$ é a intensidade da chuva em condições de steady state.

Observa-se, portanto, que os dados obtidos para as feições erosivas de Piratininga, cujos principais processos de deflagração e desenvolvimento estão vinculados às águas do escoamento subsuperficial, são conflitantes com os pressupostos do modelo utilizado por MONTGOMERY e DIETRICH (1994) para prever a formação de canais nessas condições.

Outros estudos, como VANDEKERCKHOVE et al. (2000) e VANWALLEGUEM et al. (2005), analisaram feições erosivas com diversos processos de evolução, incluindo seepage e piping, mas também escoamento superficial Hortoniano. Em ambos foi encontrada uma correlação negativa entre área de contribuição e declividade, corroborando com resultados desta pesquisa. VERACHTERT et al. (2010), ao avaliarem os limites críticos para o desenvolvimento de piping, também encontraram uma relação negativa entre $\mathrm{S}$ e $\mathrm{A}$. Os autores fazem a ressalva de que a validade física dos seus resultados depende do pressuposto de que a área de contribuição da superfície é similar à de subsuperfície.

As bases físicas do piping, que é um dos processos responsáveis pelo voçorocamento em Piratininga, estão associadas às características hidráulicas dos materiais da zona de percolação das águas subsuperficiais (SALOMÃO, 1994). Assim, o piping só pode ocorrer em uma determinada posição da encosta em locais com altos níveis de concentração de fluxo d'água subsuperficial associados a valores elevados de gradiente hidráulico, condição que é facilitada no caso da existência de surgências d'água. Supondo que o gradiente hidráulico 
esteja grosseiramente paralelo à declividade da encosta e que a área de contribuição subsuperficial não difere em grandes proporções da superficial, essas explicações legitimam ser possível uma relação negativa entre declividade e área de contribuição para a formação de voçorocas relacionadas às águas subsuperficiais. Consequentemente, locais com maior concentração das águas subsuperficiais (A) necessitam de menor gradiente hidráulico (S) para deflagrar e promover a evolução da voçoroca e vice-versa. Portanto, acredita-se que a complexidade dos processos de voçorocamento não possa ser explicada apenas por um modelo de saturação do solo, devendo envolver também a caracterização das bases físicas dos outros processos envolvidos.

O coeficiente $a$ do limite crítico topográfico é igual a 0,064 e o coeficiente $b$ é igual a 0,084. A Tabela 4 apresenta uma comparação com os coeficientes encontrados em outros trabalhos ${ }^{5}$.

\begin{tabular}{|c|c|c|c|}
\hline \multicolumn{4}{|c|}{ Tabela 4: Comparação dos coeficientes $a$ e $b$ encontrados por diversas pesquisas } \\
\hline Pesquisa & Incisão por & Coeficiente $a$ & Coeficiente $b$ \\
\hline \multirow{4}{*}{$\begin{array}{l}\text { MORGAN e MNGOMEZULU } \\
(2003)\end{array}$} & & 0,1577 & $-0,0645$ \\
\hline & Hortonian overland flow e subsurface & 0,12108 & $-0,1767$ \\
\hline & $\begin{array}{c}\text { processes (seepage) (valley-siae } \\
\text { gullies) }\end{array}$ & 0,2235 & $-0,3198$ \\
\hline & & 0,1622 & $-0,4314$ \\
\hline \multirow{2}{*}{ VANWALLEGUEM et al. (2005) } & $\begin{array}{l}\text { Hortonian e saturated overland flow } \\
\text { e seepage (shallow ephemeral gullies) }\end{array}$ & 0,020 & $-0,141$ \\
\hline & $\begin{array}{l}\text { Hortonian e saturated overland flow } \\
\text { e seepage (deep gullies) }\end{array}$ & 0,0578 & $-0,152$ \\
\hline \multirow{3}{*}{ VERACHTERT et al. (2010) } & Piping (S mensurada pelo MDT) & 0,017 & $-0,123$ \\
\hline & & & \\
\hline & Piping (S mensurada em campo) & 0,019 & $-0,140$ \\
\hline STABILE (2012) & $\begin{array}{l}\text { Escoamento subsuperficial (piping, } \\
\text { solapamento por seepage), } \\
\text { escoamento superficial eventual }\end{array}$ & 0,064 & $-0,084$ \\
\hline
\end{tabular}

\footnotetext{
${ }^{5}$ Ainda que o estudo de ARAUJO (2011) tenha sido realizado na Bacia Sedimentar do Paraná e seus dados pudessem auxiliar na interpretação dos resultados, os dados não são comparáveis, pois o autor mensurou a declividade média da área de contribuição de cada feição erosiva e não a declividade local. Além disso, os limites críticos topográficos foram definidos manualmente, sem o critério da regressão dos dados (o autor definiu limites críticos com o expoente $b$ negativo, mas a observação da distribuição dos dados permite verificar que a relação entre S e A é positiva nas formas erosivas estudadas em São Pedro).
} 
Observa-se que o coeficiente $a$ encontrado neste estudo $(0,064)$ assemelha-se aos coeficientes obtidos em outras pesquisas. VANDAELE et al. (1996) ao observar os resultados de diferentes autores, descreve que esse coeficiente é altamente variável, sofrendo a influência dos métodos usados e de características específicas do conjunto de dados. A variação atinge várias ordens de magnitude (de 0,0035 a 0,35), sendo que 0,025 foi definido como um valor típico.

O valor do coeficiente $b(-0,084)$, entretanto, é maior que os valores descritos na Tabela 4 com exceção de um dos coeficientes $(b=-0,06445)$ encontrados por MORGAN e MNGOMEZULU (2003). VANDAELE et al. (1996) afirmam que o valores encontrados por eles na bibliografia variam entre $-0,25$ e $-0,60$, sendo que $b \approx-0,40$ em vários estudos. MONTGOMERY e DIETRICH (1994) associam $b$ ao processo que desencadeou o canal (ou a feição erosiva), estimando que $b \approx-0,5$ para canais gerados pelo escoamento superficial, tendendo a ter maiores valores quando os canais são originados pelos escorregamentos.

MORGAN e MNGOMEZULU (2003) descrevem que as feições erosivas por eles mapeadas, em geral, são atribuídas ao escoamento superficial. Contudo, em duas das quatro áreas estudadas eles encontraram $b<-0,2$, e concluíram que ou os processos de subsuperfície (seepage) teriam influência na evolução dessas feições após a incisão pelo escoamento superficial, ou que sua inferência de que maiores valores de $b$ refletem esse tipo de processo é um erro.

Considerando que os trabalhos descritos por VANDAELE et al. (1996) foram realizados principalmente em canais formados pelo escoamento superficial e que os estudos de VANWALLEGUEM et al. (2005) e VERACHTERT et al. (2010) compreenderam feições erosivas associadas ao runoff subsuperficial, o valor do coeficiente $b$ aqui encontrado $(-0,084)$ possivelmente reflete os processos de voçorocamento pelas águas subsuperficiais.

A Figura 44 mostra que o limite crítico estabelecido é difuso, ou seja, que nem todos os locais que estão acima do limiar para a formação de canais efetivamente vão gerar canais. É possível verificar que a maior parte da área do entorno das feições erosivas está acima do limite crítico, restando os topos e os noses mais suaves abaixo. Sobre isso, DIETRICH et al. (1993) argumentam que os locais acima do limite crítico são propensos ao desenvolvimento de canais, todavia, devido à variações locais em certas propriedades como a condutividade hidráulica saturada e o ângulo de fricção, ou mais provavelmente, devido à tendência dos processos de transporte de sedimentos difusos em preenchê-los, os canais não incidem em tais áreas. 


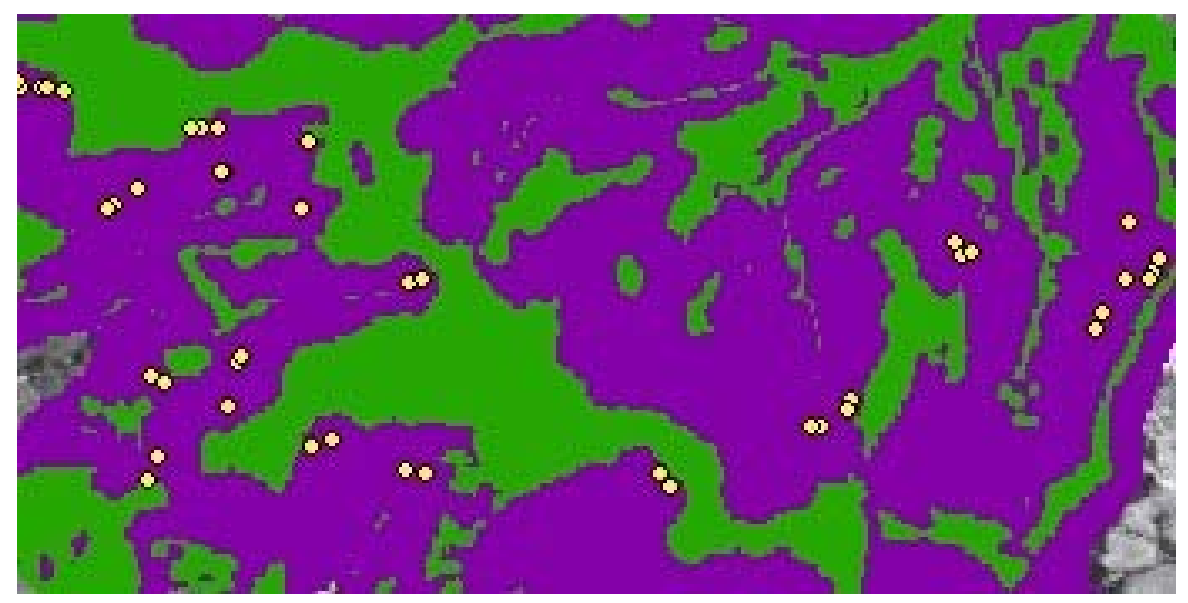

Figura 44: Representação espacial do limite crítico topográfico para as feições erosivas sem condicionamento antrópico. Áreas abaixo do limite crítico (verde), as áreas acima do limite crítico (roxo) e as feições erosivas sem condicionamento antrópico (ć́rculos amarelos). Escala aproximada 1:30.000.

Quanto às feições com condicionamento antrópico (Figura 43), observa-se que elas estão plotadas de modo esparso ao longo dos dados de S e A. Chama a atenção, porém, dois grupos de feições erosivas com condicionamento antrópico:

- Grupo 01: formado pelas três feições erosivas que estão abaixo do limite crítico. Tratam-se das feições cujo condicionamento antrópico refere-se à presença de uma estrutura concentradora de água (classe IVa). Comprova-se assim que essas feições não existiriam em condições normais. Tomando-se como base o ponto $(0,0145 ; 0,066)$, pode-se calcular que na cabeceira de uma feição erosiva com essa declividade local, seria necessária uma área de contribuição de aproximadamente 1 hectare para ocorrer a erosão, isto é, quase 70 vezes mais do que a estimada para esse ponto.

- Grupo 02: constituído por quatro feições erosivas com $\mathrm{A}>0,1$ hectares e que, desse modo, destoam da média de área de contribuição. São feições classificadas como IVb ou IVc, ou seja, que foram ao menos parcialmente enterradas. Nas fotografias aéreas é possível constatar que em todos esses casos as feições tiveram suas cabeceiras enterradas (Figura 45) e, por conseguinte, os valores de área de contribuição referem-se ao corpo das feições em partes não enterradas, obviamente com áreas de contribuição maiores que a média. 


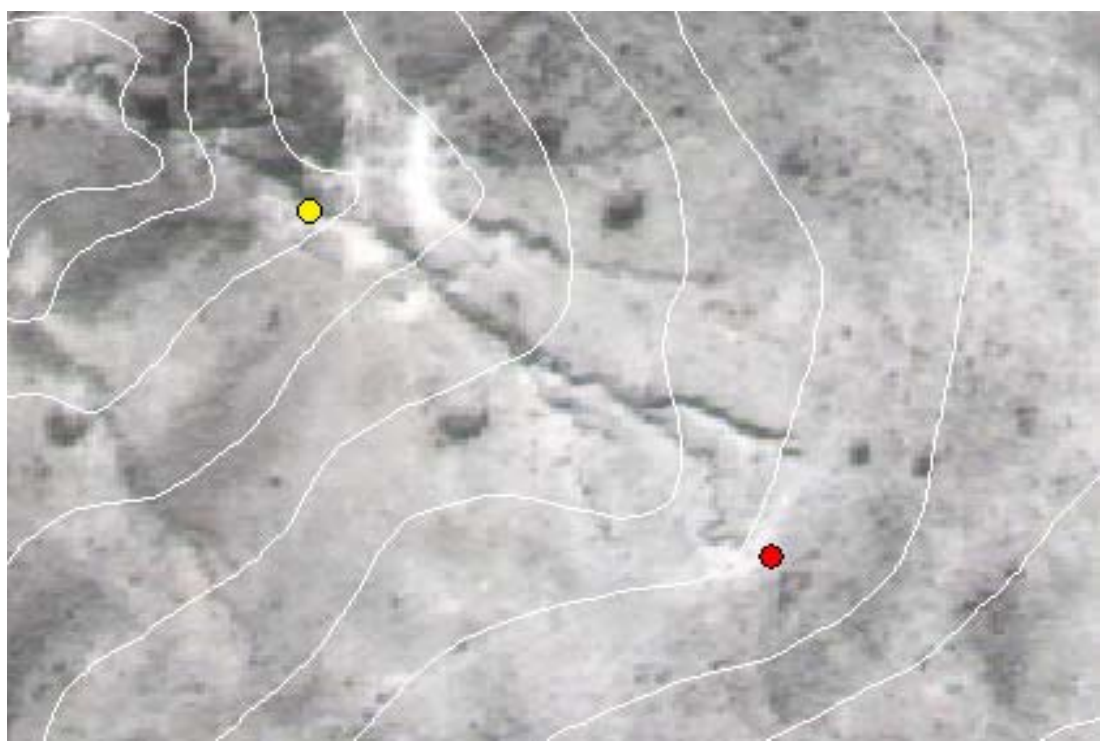

Figura 45: Recorte ampliado da fotografia aérea de 1972, com a marcação da cabeceira da feição erosiva classe IV (círculo vermelho) e a marcação da cabeceira da feição após ser enterrada (círculo amarelo). Escala aproximada: 1:3.000. Fonte da fotografia aérea: Instituto Brasileiro do Café (1972).

\subsection{Limites Críticos Topográficos: Instabilidade e Estabilidade das Feições Erosivas}

A caracterização das feições erosivas permitiu a distinção entre feições erosivas com ausência de processos atuais (estabilizadas), com poucos processos atuais (quase estabilizadas) e com presença de processos atuais (ativas) (Figura 46). Ressalta-se que mesmo as feições consideradas ativas apresentam, na sua maioria, uma velocidade muito baixa de recuo das cabeceiras, de no máximo alguns centímetros por ano.

Os dados de S e A referentes a essa classificação baseada na frequência dos processos também foram avaliados (Figura 47). A distinção entre feições erosivas onde ainda há indícios de recuo das cabeceiras e feições erosivas que já atingiram o equilíbrio, fornece bases empíricas para a discussão da evolução das feições erosivas em relação ao limite crítico topográfico.

É visível a diferença nas relações entre $\mathrm{S}$ e A para as feições erosivas com processos atuais e as feições onde os indicadores de atividade atual são ausentes. Essas relações são expressas pelas respectivas equações de regressão que demonstram que as feições erosivas com ausência de processos atuais estão mais próximas do limite crítico topográfico que as feições ativas (o coeficiente $a$ é menor para as primeiras). 
(a)
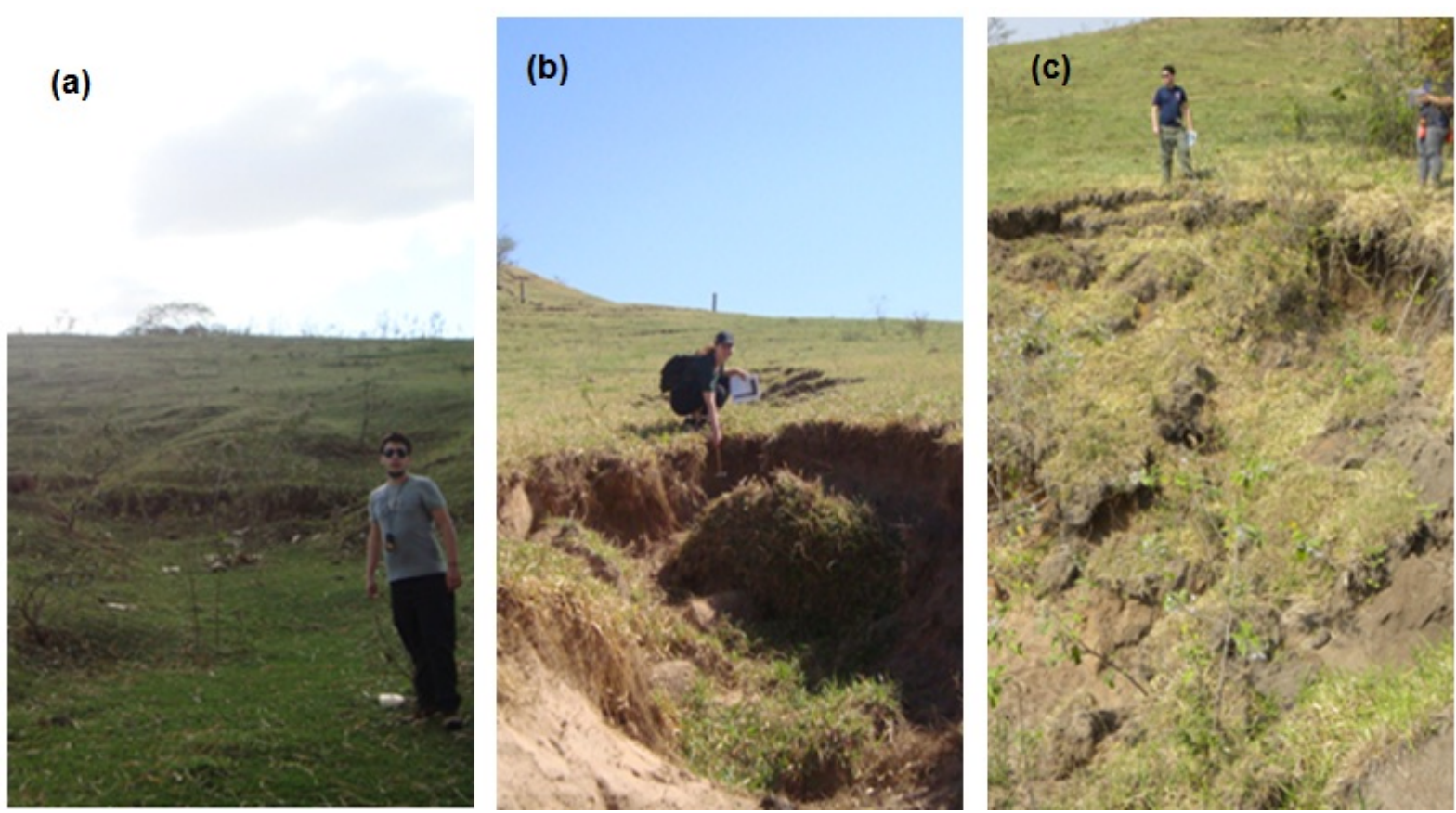

Figura 46: Exemplos de cabeceiras de feições erosivas classificadas como: com ausência de processos atuais (a); com poucos processos atuais (b); e, com presença de processos atuais (c).

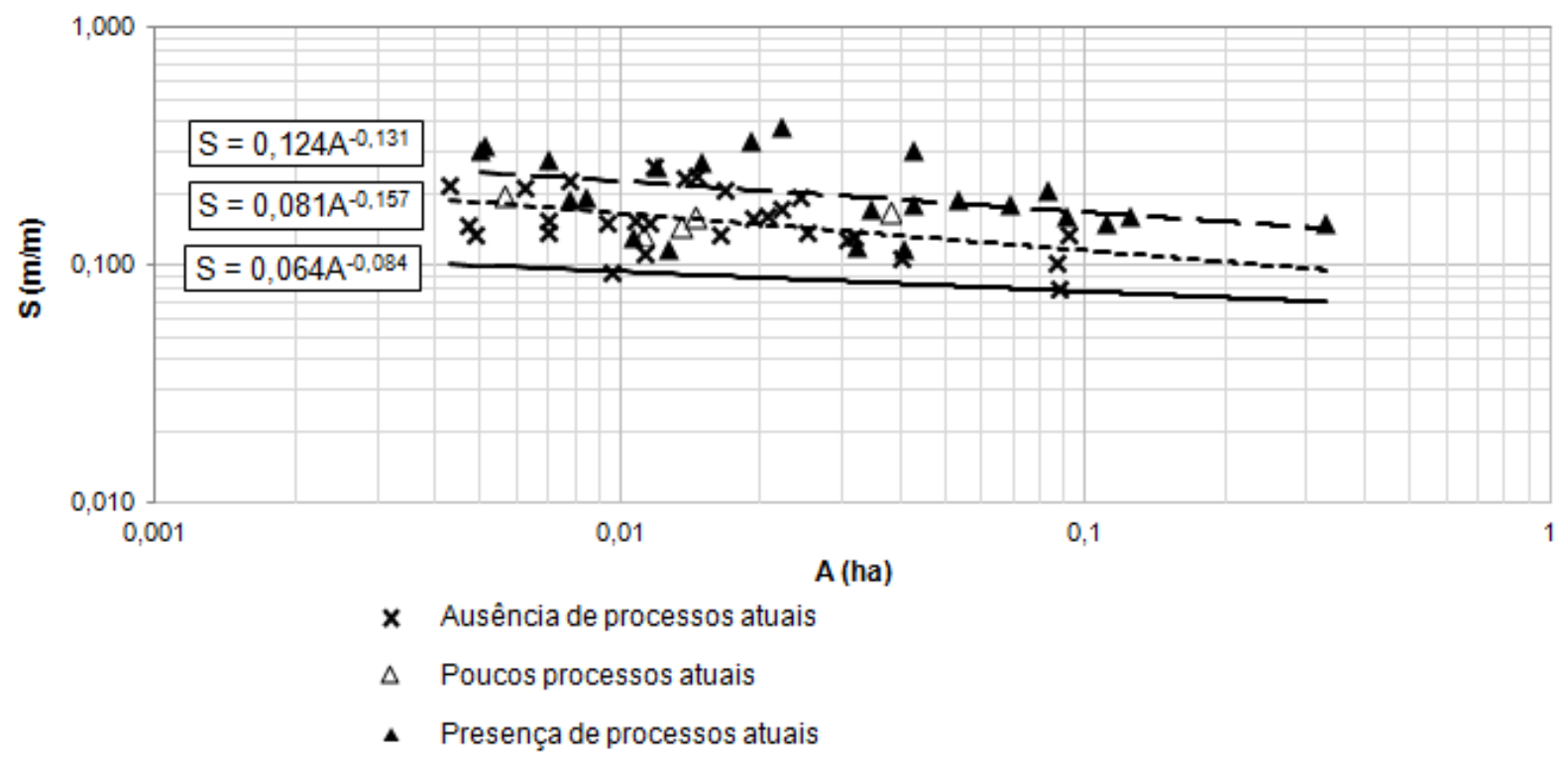

— - Linha de regressão das cabeceiras com presença de processos atuais

----- Linha de regressão das cabeceiras com ausência de processos atuais

Limite crítico das feições erosivas sem condicionamento antrópico

Figura 47: Relação entre área de contribuição e declividade para as feições erosivas com ausência de processos atuais, com poucos processos atuais e com presença de processos atuais. Também estão indicadas no gráfico as linhas de regressão para as feições erosivas com ausência de processos atuais e com presença de processos atuais, assim como o limite crítico das feições erosivas sem condicionamento antrópico. 
Na proposta teórica de MONTGOMERY e DIETRICH (1988; 1994), as cabeceiras dos canais situam-se no primeiro ponto a jusante do divisor de águas no qual há área de contribuição suficiente para manter um canal. Desse modo, considerando o limite crítico como ponto máximo que as feições erosivas têm a possibilidade de alcançar, as observações da presente pesquisa permitem afirmar que as feições erosivas estabilizadas estão mais próximas das condições máximas de desenvolvimento, e por isso, não se observam mais processos de recuo das suas cabeceiras. Por outro lado, as feições erosivas ativas estão um pouco mais distantes do limite crítico e, por esse motivo, ainda têm área de contribuição suficiente para promover o recuo de suas cabeceiras, como é evidenciado pelos solapamentos encontrados nas cabeceiras dessas feições.

Sobre a migração das cabeceiras, MONTGOMERY e DIETRICH (1994) argumentam que a posição da cabeceira do canal pode flutuar a montante e jusante em reposta a mudanças de clima, de uso do solo ou variações sazonais. Os autores detalham ainda que a área de contribuição vai diminuir caso ocorra o aumento da chuva, o decréscimo na capacidade de infiltração do solo ou a diminuição da tensão de cisalhamento crítica. Similarmente, modificações de uso do solo que aumentam a intensidade efetiva da chuva na superfície, ou que diminuem tanto a capacidade de infiltração como a tensão de cisalhamento crítica resultariam em avanço remontante da cabeceira do canal, erosão acelerada e expansão da rede de canais.

Considera-se, por conseguinte, que as feições erosivas estudadas foram ativadas por mudanças bruscas de uso do solo, especificamente pelo desflorestamento (SALOMÃO, 1994; CASTRO e QUEIROZ NETO, 2009), ocasionando modificações similares às descritas por MONTGOMERY e DIETRICH (1994) em relação à intensidade da chuva na superfície, à capacidade de infiltração e à tensão de cisalhamento crítica. Dessa maneira, as surgências d'água que apareceram com o aprofundamento e alargamento das calhas dos rios (SALOMÃO, 1994), passaram a formar canais que recuaram remontantemente. Em 1972 a evolução das feições já atingia quase o limite máximo permitido pela área de contribuição disponível, de modo que desde então as voçorocas se desenvolveram muito pouco.

As linhas de regressão demonstram, por fim, que algumas dessas feições já estão muito próximas do equilíbrio entre declividade e área de contribuição, enquanto que outras ainda dependem da evolução remontante para chegar a tal equilíbrio. É claro que as variações pedológicas e de uso do solo exercem importante papel em tais processos, como fica subentendido na Figura 47 pelas variações significativas dentro de cada classe entre as 
distâncias das feições ativas e estáveis do limite crítico, entretanto, na média (linha de regressão) a relação entre S e A consegue delinear a dinâmica erosiva.

As mudanças de uso do solo desde 1972 até os dias atuais podem explicar porque diversas feições erosivas já estariam estabilizadas mesmo sem estarem abaixo do limite crítico. Isto é, a adoção de práticas agrícolas menos agressivas, incluindo medidas de conservação do solo, pode ter modificado o limite crítico topográfico (que foi estabelecido com base em cabeceiras de feições erosivas que já existiam em 1972), fazendo com que algumas feições erosivas se estabilizassem e até mesmo passassem a ter uma dinâmica que MONTGOMERY e DIETRICH (1988) denominaram de preenchimento agradacional das cabeceiras dos canais de primeira ordem. Essa possivelmente é a condição atual de diversas das feições erosivas denominadas de canal gramado (classes Ic e IIf).

Um tópico que deve ser enfatizado refere-se à forma pela qual ocorre a evolução remontante e a consequente diminuição da área de contribuição. A base teórica de MONTGOMERY e DIETRICH $(1988 ; 1994)$ assume a declividade como uma variável independente nessa relação, ou seja, ela não se altera com a variação da área de contribuição. Obviamente, esse é um pressuposto válido exclusivamente no modelo teórico. Na realidade, $\mathrm{S}$ e A variam conjuntamente. Nas feições erosivas estudadas, as encostas a montante das cabeceiras dos canais atuais têm em sua maioria perfil convexo, ainda que sua forma em planta seja essencialmente côncava.

A Figura 48 explica como os pontos se deslocariam no gráfico da relação entre S e A em encostas retilíneas e como os pontos tendem a se deslocar em encostas convexas. Nestas últimas, perfil encontrado nas cabeceiras das feições erosivas da área de estudo, a diminuição da área de contribuição é acompanhada pela diminuição da declividade, fazendo com que a condição de equilíbrio seja atingida mais rapidamente do que se a encosta tivesse perfil retilíneo. Notadamente, caso a evolução remontante ocorresse em perfil retilíneo (Figura 48a), devido ao baixo coeficiente $b$ do limite crítico topográfico, seriam necessárias áreas de contribuição extremamente pequenas para permitir a estabilização das voçorocas, o que faria com que suas cabeceiras se localizassem praticamente junto ao divisor de águas.

Existem também encostas côncavas em perfil a montante das cabeceiras das feições erosivas atuais da área de estudo. Porém, nestas circunstâncias, muitas vezes ocorre o afloramento do substrato rochoso (arenito) a montante do eixo da concavidade, que por sua vez pode exercer um controle estrutural no recuo das cabeceiras, fazendo com as mesmas se estabilizem antes de alcançarem a área de contribuição ideal. 
Tal como já informado, considerando a predominância de processos movidos pelo escoamento subsuperficial, todas essas constatações dependem da validade da hipótese de que a declividade superficial corresponde ao gradiente hidráulico, assim como a área de contribuição superficial obedece aos limites piezométricos. Caso contrário, poderão ocorrer processos do tipo captura de drenagem e outras ocorrências imprevistas.

(a)
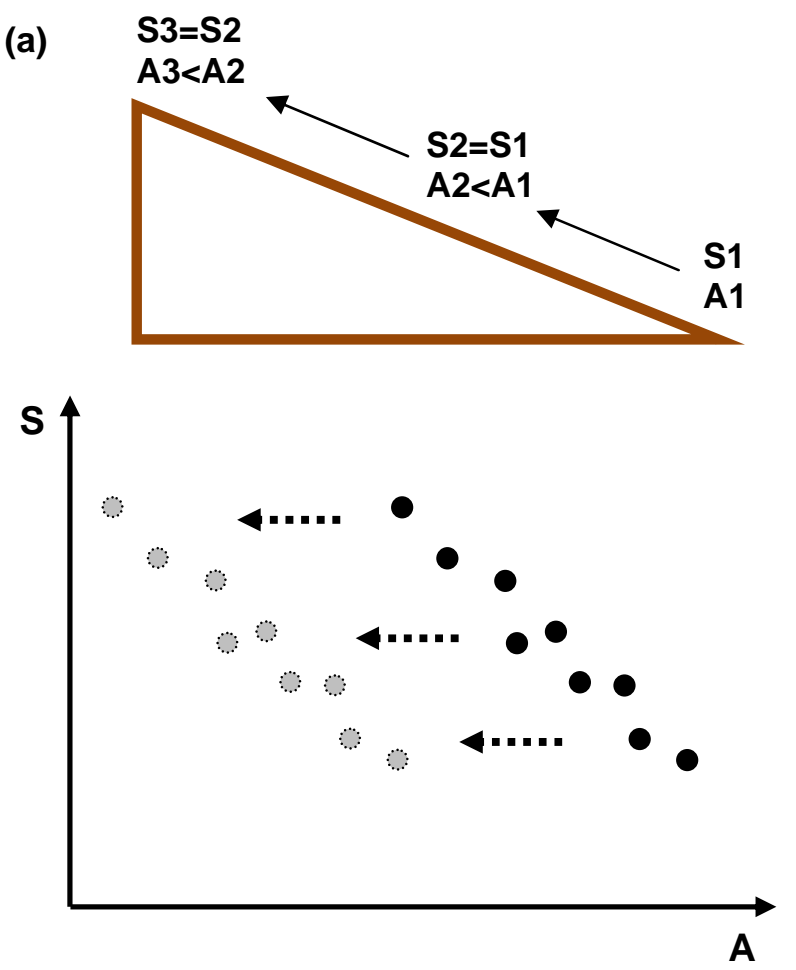

- Posição inicial da cabeceira das feições erosivas (b)
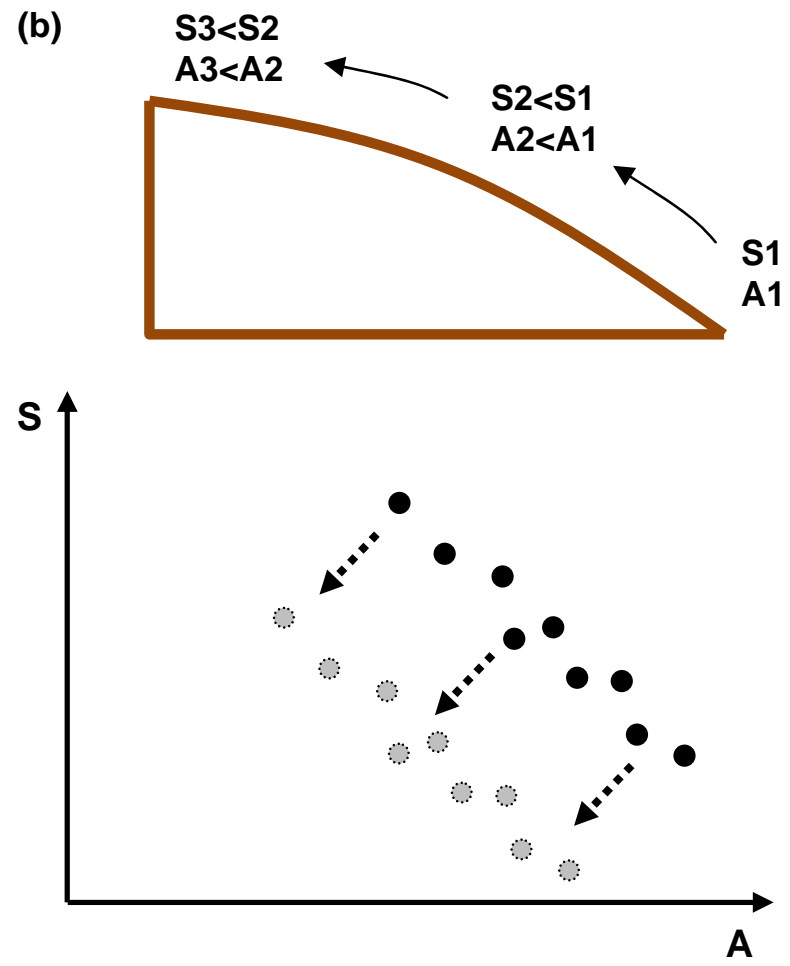

Posição da cabeceira das feições erosivas após evolução remontante

Figura 48: Modelos teóricos de variação da declividade de acordo com a diminuição da área de contribuição: (a) modelo teórico para encostas retilíneas, ou seja, sem variação da declividade; (b) modelo teórico para encostas convexas, ou seja, com diminuição da declividade e diminuição da área de contribuição. 


\subsection{Limites Críticos Topográficos: Deflagração das Voçorocas}

A fim de identificar se os pontos de deflagração das voçorocas também estão inseridos acima do limite crítico topográfico estabelecido e caracterizar como ocorreu a evolução dessas feições erosivas até a cabeceira, a correlação entre $\mathrm{S}$ e A foi examinada também para os pontos gerados a partir da observação das fotografias aéreas de 1972 (locais de início e cabeceiras das voçorocas) (Figura 49). Dois pontos de início das voçorocas foram excluídos das análises sendo considerados outliers, pois eles estavam situados em canais onde a fotointerpretação não permitia distinguir entre o local de início do voçorocamento e os locais onde apenas havia uma forte incisão e alargamento das margens do curso d'água.

Os pontos de início das voçorocas, assim como as cabeceiras mapeadas em 1972, situam-se todos acima do limite crítico definido inicialmente. Consequentemente, fica evidenciado que assim como as feições erosivas só se desenvolvem em áreas acima do limite crítico, os limiares topográficos também definem os locais onde as feições erosivas podem se iniciar.

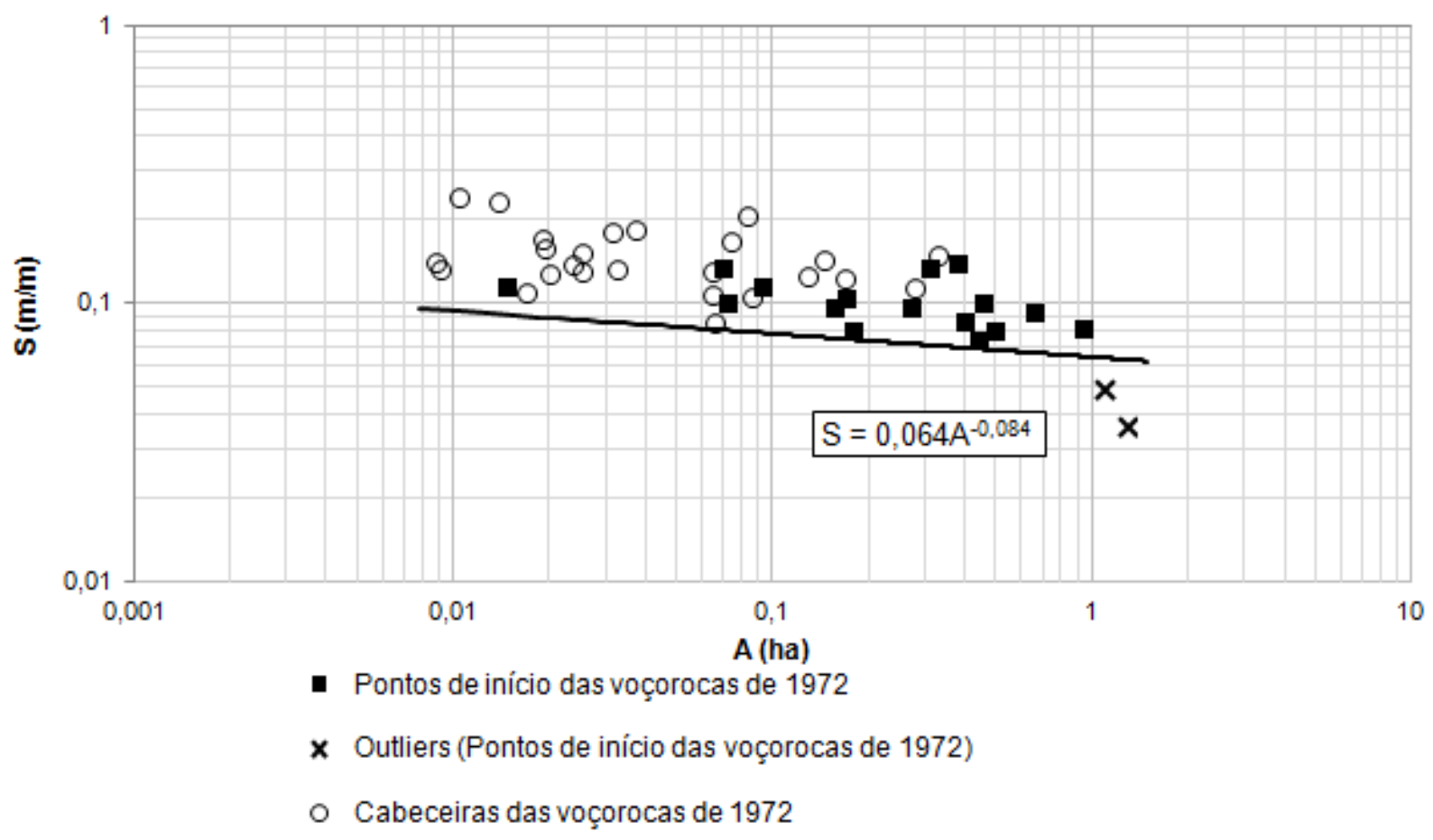

Figura 49: Relação S x A para os pontos de início e para cabeceiras das voçorocas mapeadas em 1972. Também está indicado no gráfico o limite crítico das feições erosivas sem condicionamento antrópico. 
O principal indicador da dinâmica das feições erosivas entre o ponto de início e as cabeceiras (Figura 49) é a variação da área de contribuição. Os pontos de início das voçorocas têm uma média de área de contribuição de cerca de 0,414 hectares, enquanto que as cabeceiras têm área de contribuição média aproximadamente igual a 0,071 hectares (quase seis vezes menor). Considerando que os pontos de início e as cabeceiras mapeadas em 1972 referem-se às mesmas voçorocas, é possível identificar que a evolução remontante das voçorocas entre seu ponto de início e a posição final da cabeceira, além da diminuição da área de contribuição, foi caracterizada pelo aumento da declividade local acima das cabeceiras das feições, tipicamente de perfis de encostas côncavas (Figura 50).
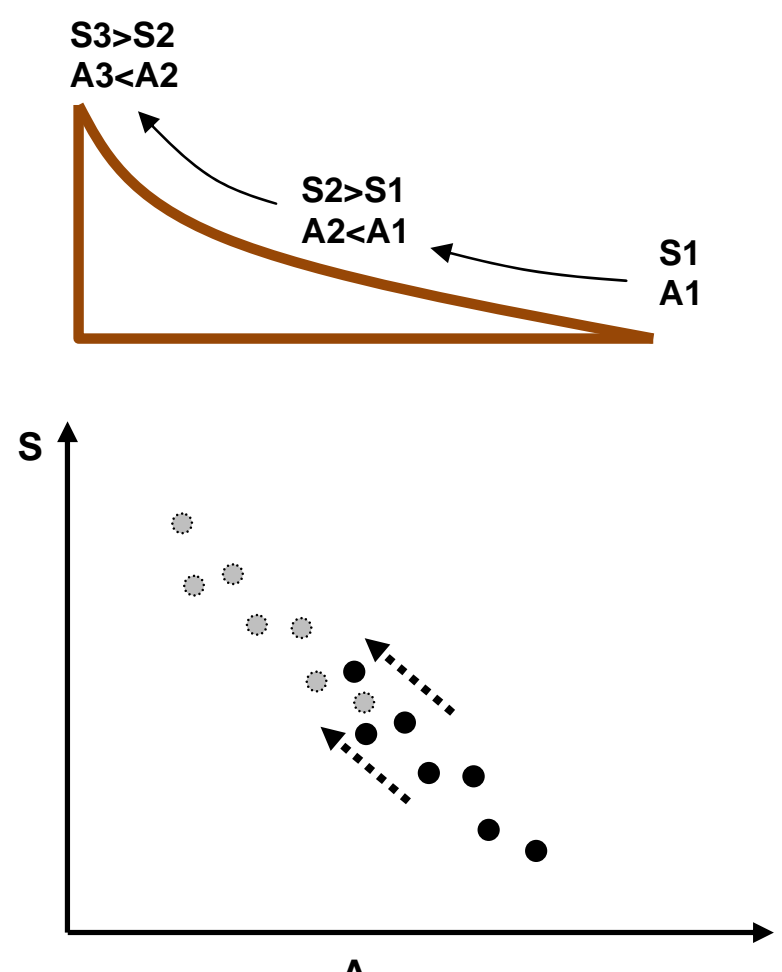

- Posição inicial da cabeceira das feições erosivas

Posição da cabeceira das feições erosivas após evolução remontante

Figura 50: Modelo teórico de variação da declividade de acordo com a diminuição da área de contribuição para encostas côncavas, ou seja, com aumento da declividade e diminuição da área de contribuição.

A tendência de aumento da declividade com a diminuição da área de contribuição desde o ponto de deflagração da voçoroca até a sua cabeceira pode ter como explicação o fato de que as feições erosivas analisadas normalmente se iniciam junto aos cursos d'água em locais relativamente planos ou na porção inferior de rupturas côncavas na encosta. Desse modo, em todos os casos, ao menos o terço inferior das encostas que estão a montante do ponto de início 
das voçorocas são côncavos, diferentemente dos setores de encosta a montante das cabeceiras das feições erosivas estudadas que são convexos (Figura 51).

Como implicação dessa tendência identificada, constata-se que muito dificilmente uma voçoroca irá se estabilizar (ou deixar de evoluir remontantemente) em setores côncavos em perfil na encosta, pois a relação entre $\mathrm{S}$ e A tende a estar sempre acima do limite crítico topográfico, diferentemente de quando a encosta é convexa ou retilínea. Entre as únicas possibilidades de uma voçoroca deixar de avançar em encostas côncavas em perfil está o substrato, ou seja, nos casos em que a declividade aumenta tanto a montante que permite exclusivamente o desenvolvimento de solos rasos ou até mesmo provoca o afloramento do substrato rochoso.
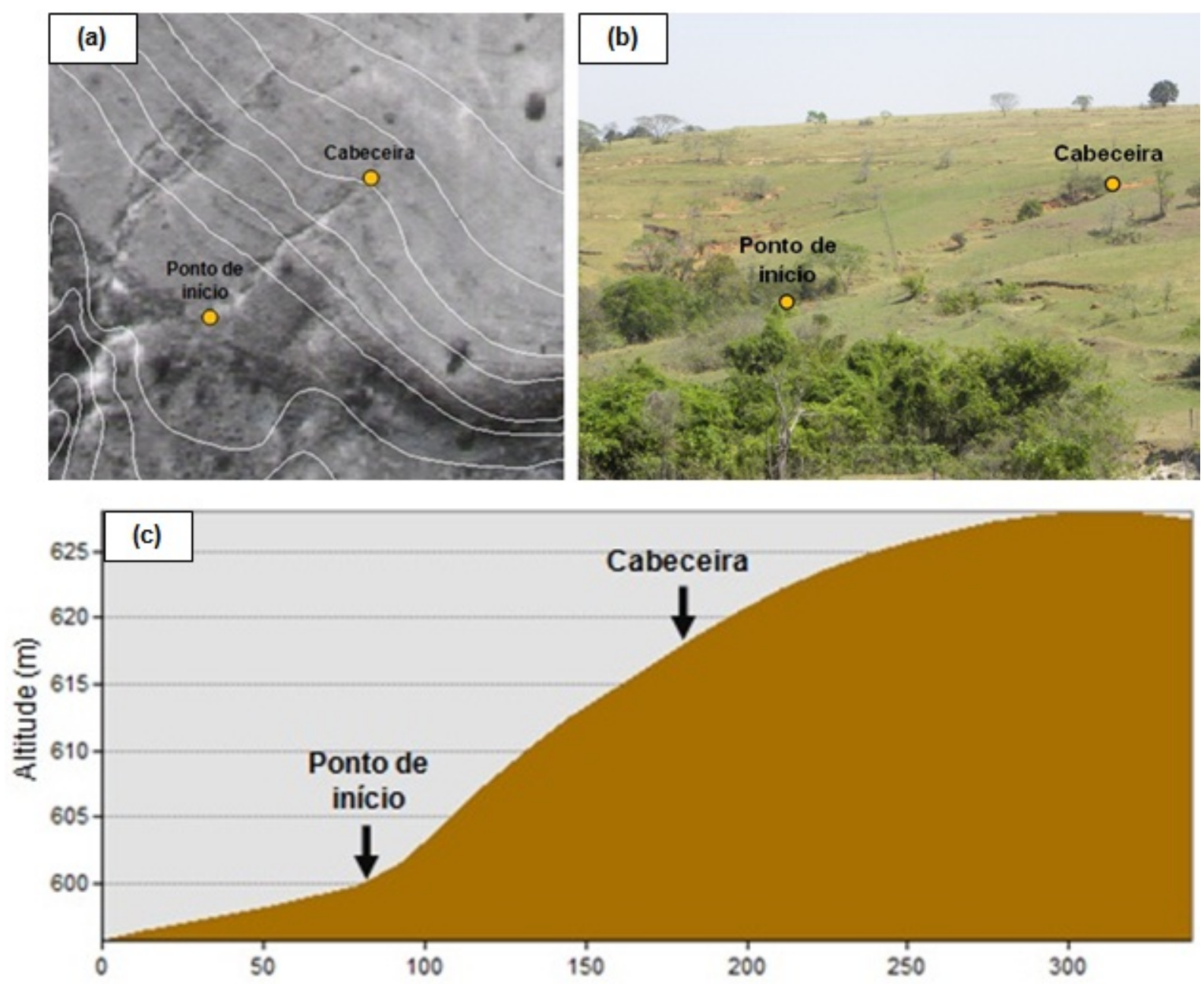

Figura 51: Exemplo de feição erosiva com ponto de início em setor da encosta côncavo em perfil e com cabeceira em setor da encosta com perfil convexo: (a) fotografia aérea ampliada (escala aproximada 1:5.000) com detalhe da feição erosiva e curvas de nível de 5 em 5 metros; (b) vista da feição erosiva em campo; (c) perfil da encosta onde se situa a feição erosiva. 


\subsection{Limites Críticos Topográficos: Classificação das Feições Erosivas}

A Figura 52 apresenta a relação SA para as classes I e III e a Figura 53 para a classe II. As tipologias de voçoroca de cabeceira (Classe I) têm uma correlação positiva entre S e A quando analisadas isoladamente. O contrário ocorre com as voçorocas de encosta (Classe II), que de maneira geral apresentam coeficiente $b$ negativo para a relação SA. A explicação mais plausível para o primeiro caso é a alta concentração de feições erosivas estabilizadas em uma área de contribuição específica (entre 0,009 e 0,020 hectares), que estão mais próximas do limite crítico e têm alto peso no estabelecimento da correlação.

A distribuição das classes de feições também permite avaliar que as diversas classes estão fortemente regionalizadas no gráfico pela sua área de contribuição. No caso das voçorocas de cabeceira (Classe I), as de fundo plano situam-se em locais com maiores áreas de contribuição que as voçorocas de fundo inclinado. Já nas voçorocas de encosta (Classe II), identifica-se que as circulares ativas têm, genericamente, áreas de contribuição menores que as circulares inativas (Figura 53). Sobre as duas únicas feições lineares de encosta verifica-se que ambas encontram-se plotadas em posições "normais" em relação às outras tipologias.

Nas voçorocas de cabeceira (Classe I) três pontos chamam a atenção: $(0,019 ; 0,334)$, $(0,022 ; 0,379) ;(0,042 ; 0,302)$, que são as três cabeceiras de voçorocas com fundo inclinado (classe Ib) de maior declividade local acima da cabeceira. Estas três cabeceiras correspondem precisamente aos locais onde foi observado em campo um maior controle estrutural nas cabeceiras, com o afloramento de arenitos da Formação Marília com cimentação carbonática de forma pronunciada (Figura 54). Essas cabeceiras de feições erosivas do tipo Ib com presença de arenito de cimentação carbonática podem estar razoavelmente estabilizadas (foram encontradas poucos casos de quedas de bloco como únicas evidências de processos atuais). Contudo, como elas estão distantes do limite crítico topográfico, essa estabilização não é explicada pela relação SA, que em teoria ainda permitiria que a feição erosiva evoluísse remontantemente, mas sim pela barreira estrutural que o arenito representa.

Essas três cabeceiras diferem substancialmente das demais cabeceiras classificadas como com fundo inclinado (Figuras 55). Estas últimas também têm o afloramento do arenito próximo à cabeceira como característica, porém o afloramento se dá de maneira menos abrupta e é possível observar uma camada de material inconsolidado sobrejacente diferentemente das primeiras onde o afloramento do substrato promove a formação de verdadeiros paredões rochosos. 


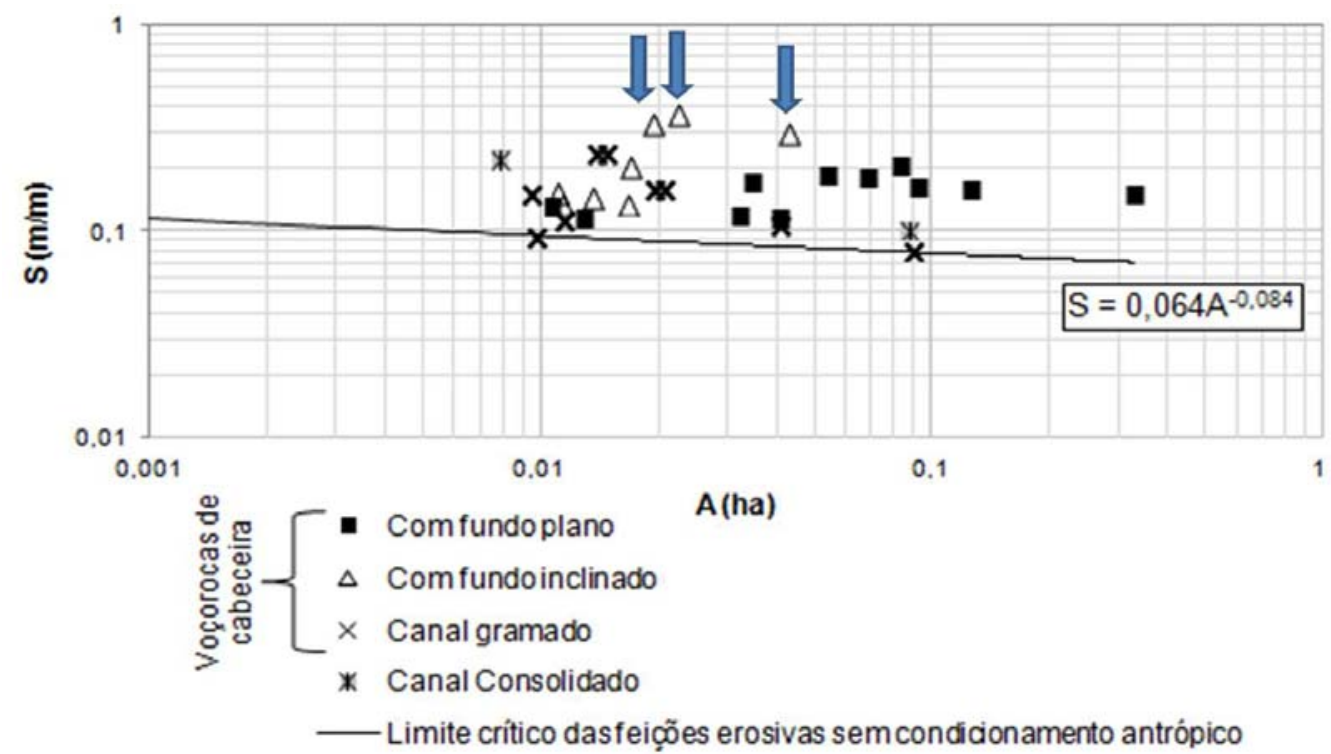

Figura 52: Relação SA para feições erosivas classificadas como voçorocas de cabeceira (classe I) e como canal consolidado (classe III). Também está indicado no gráfico o limite crítico das feições erosivas sem condicionamento antrópico e as cabeceiras de feições erosivas do tipo Ib relativamente mais abruptas (setas azuis).

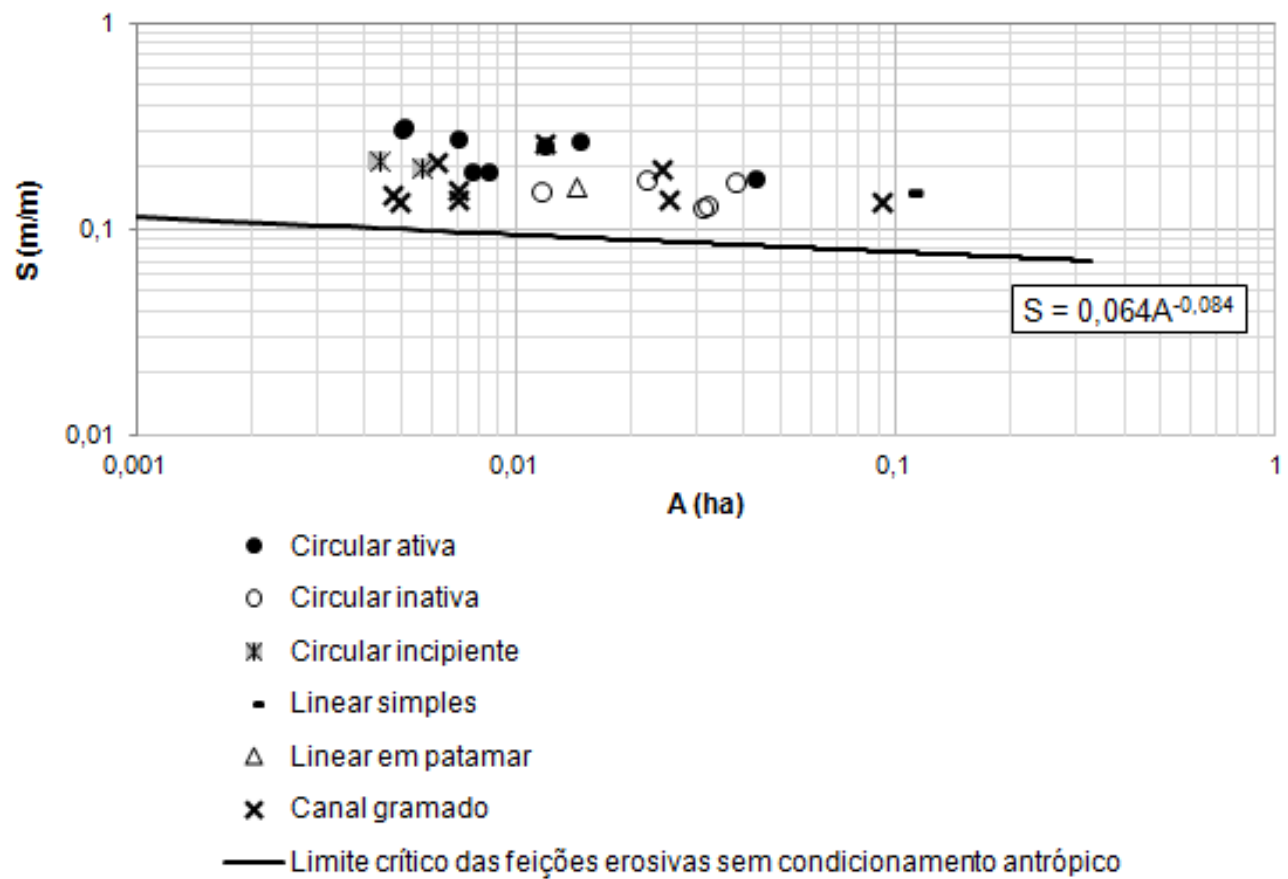

Figura 53: Relação entre área de contribuição e declividade para feições erosivas classificadas como voçorocas de encosta (classe II). Também está indicado no gráfico o limite crítico das feições erosivas sem condicionamento antrópico. 


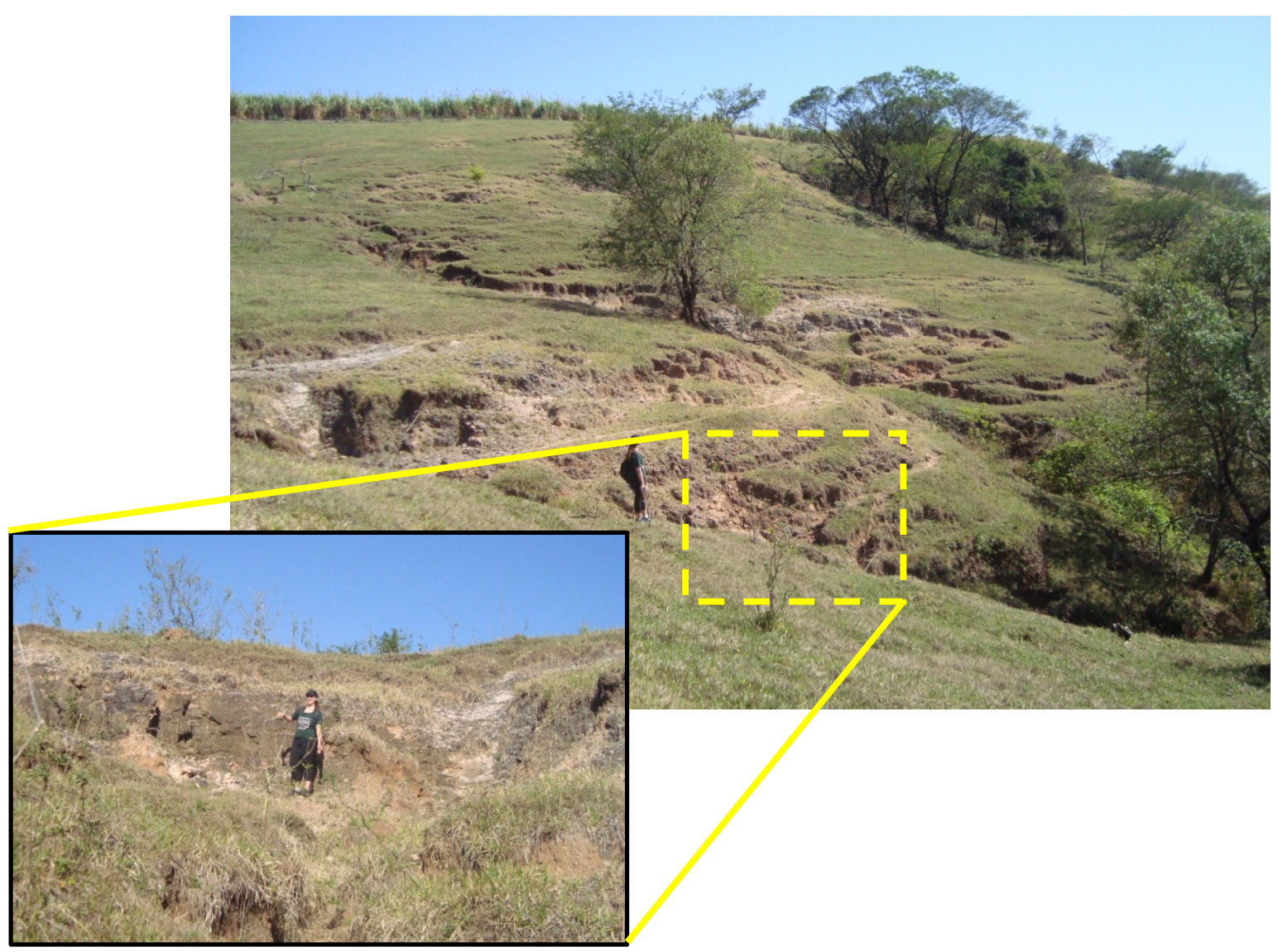

Figura 54: Cabeceira do tipo Ib, relativamente mais abrupta, formando paredões rochosos devido à presença de arenito com sedimentação carbonática.

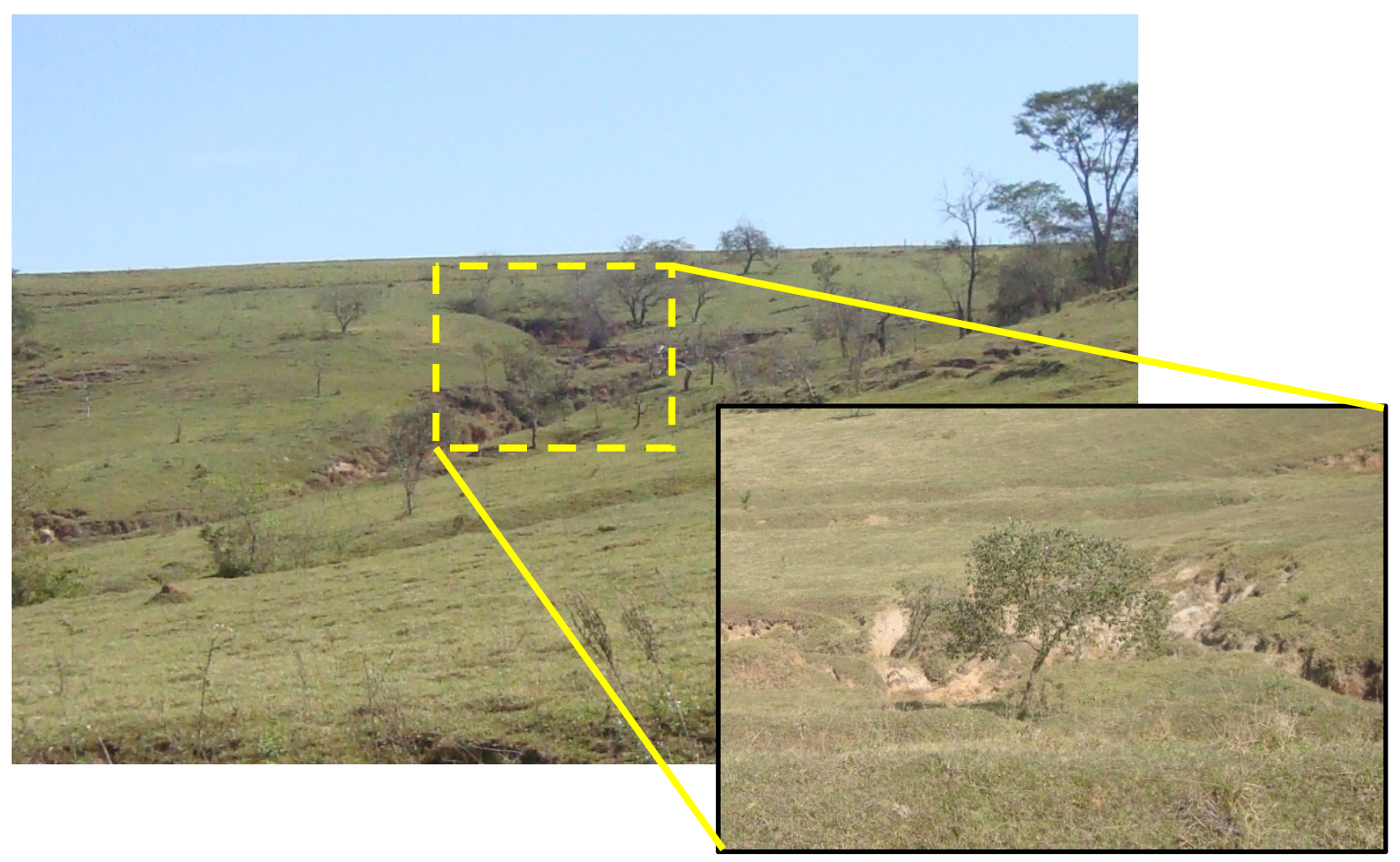

Figura 55: Cabeceira do tipo $\mathrm{Ib}$, relativamente menos abrupta e com material inconsolidado sobrejacente ao arenito. 
Como complementação à classificação das feições erosivas atuais, as cabeceiras de sulcos e ravinas mapeados nas fotografias aéreas de 1972 são apresentadas quanto à sua relação entre declividade local acima da cabeceira e área de contribuição (Figura 56).

Os sulcos e ravinas ocorrem também abaixo do limite crítico topográfico definido a partir da relação SA das maiores feições erosivas atuais (principalmente voçorocas). É igualmente visível que não há uma distinção entre as áreas onde ocorre um ou outro processo, visto que os sulcos e ravinas também incidem acima do limite crítico topográfico. Nesses casos, VANDAELE et al. (1996) ponderam que, para uma dada declividade, as feições erosivas menores se formam com menores áreas de contribuição acima da cabeceira, pois essas feições ocorrem mesmo com menores intensidades de runoff. Isso significa que o limite crítico para a deflagração e desenvolvimento de sulcos e ravinas é menor que o limiar topográfico que restringe os voçorocamentos. Para VANWALLEGUEM et al. (2005), ao verificarem menores limiares para a ocorrência de shallow gullies do que para deep gullies, o fato de diversas shallows gullies ocorrerem acima do limiar das deep gullies, demonstra que o limite crítico deve ser interpretado com cuidado, no sentido de que assim como nem todos os locais inseridos acima do limiar para shallow gullies se transformam em shallow gullies, nem todas as shallow gullies acima do limite crítico para deep gullies se tornarão deep gullies. No caso desta pesquisa isso significa que não é porque os sulcos e ravinas estão acima do limite crítico para o desenvolvimento de voçorocas, que essas feições efetivamente vão evoluir para voçorocas.

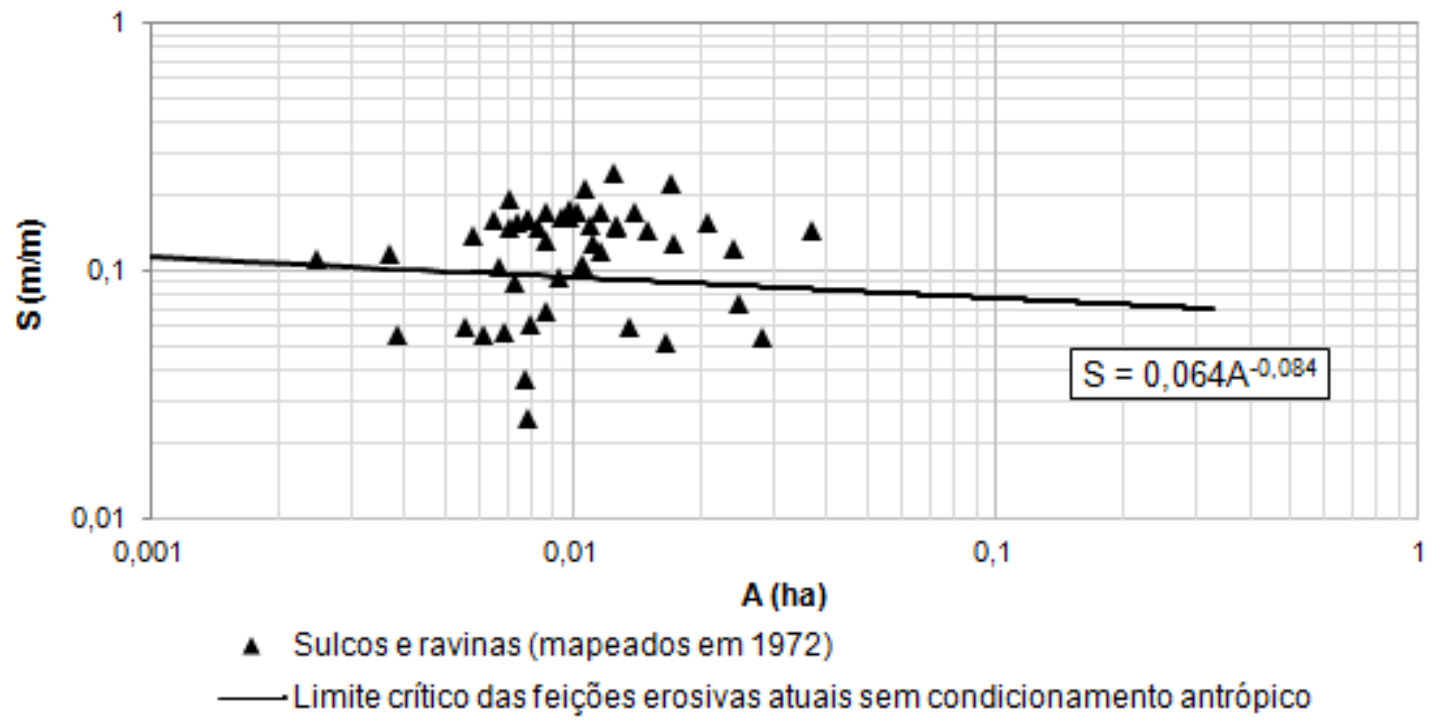

Figura 56: Relação SA para feições erosivas classificadas sulcos e ravinas. Também está indicado no gráfico o limite crítico das feições erosivas sem condicionamento antrópico. 


\section{CONCLUSÕES}

A abordagem dos limites críticos topográficos permitiu o avanço na compreensão da dinâmica das feições erosivas lineares em Piratininga (SP), e, consequentemente da dinâmica erosiva de relevos com substrato sedimentar no meio tropical úmido. A relação SA acima da cabeceira das feições erosivas lineares mostrou-se útil na identificação das condições críticas para a deflagração, desenvolvimento e estabilização das feições erosivas lineares, corroborando com os pressupostos de que esta abordagem fornece um bom quadro conceitual para investigar as respostas do relevo (voçorocas e demais feições erosivas) a alterações na energia do sistema geomorfológico.

A comparação entre os dados de declividade coletados demonstrou que não só as dimensões do local de mensuração da declividade acima da cabeceira da feição erosiva influenciam na variação dos dados de declividade, como também que o método de mensuração de campo fornece resultados muito pouco correlacionados aos dados gerados pelo Modelo Digital de Terreno (MDT). Também foi observado que as diferentes resoluções de MDT geram informações de declividade e área contribuição díspares, principalmente no caso da área de contribuição. Por isso, os dados de todas as análises de declividade e área de contribuição foram extraídos do MDT com resolução de 10 x 10 m, que foi considerado mais preciso dentre as alternativas estudadas.

O limite crítico topográfico foi obtido com o ajuste da linha de regressão no limite inferior do gráfico de dispersão dos dados de declividade e área de contribuição. O limiar encontrado apresenta um expoente $b$ negativo, ou seja, a declividade tende a diminuir com o aumento da área de contribuição. Esse expoente conflita com os modelos matemáticos em bases físicas que descrevem canais formados a partir do escoamento subsuperficial (saturação do solo), nos quais se prevê uma correlação positiva entre declividade e área de contribuição. Por outro lado, o valor do expoente $b$ é similar ao de outros trabalhos que avaliaram os limiares topográficos para feições erosivas resultantes do escoamento subsuperficial (piping e seepage).

Acredita-se que a complexidade dos processos de voçorocamento da área de estudo não possa ser explicada apenas por um modelo de saturação do solo, devendo envolver também a caracterização das bases físicas dos outros processos envolvidos como, por exemplo, do piping, que é dependente da concentração das águas subsuperficiais e do gradiente hidráulico. Considerando a predominância de processos movidos pelo escoamento subsuperficial, 
adotou-se o pressuposto de que a declividade superficial corresponde ao gradiente hidráulico, assim como a área de contribuição superficial obedece aos limites piezométricos.

Foi demonstrado que o limite crítico estabelecido é difuso, ou seja, que nem todos os locais que estão acima do limiar para a formação de canais efetivamente vão gerar canais. Entretanto, além das cabeceiras das feições erosivas, os pontos de início dos processos erosivos mapeados situam-se acima do limite crítico, corroborando que o limite crítico topográfico é válido tanto para a evolução como para a deflagração das feições erosivas lineares.

A influência antrópica (ex. estruturas de concentração de água) gera processos erosivos lineares em locais onde normalmente eles não ocorreriam devido à influência antrópica no runoff, ou seja, algumas feições erosivas localizam-se abaixo do limite crítico, em encostas com áreas de contribuição dezenas de vezes menores do que as necessárias para o rompimento do limiar.

A distinção entre as feições erosivas onde ainda há indícios de recuo das cabeceiras e feições erosivas que já atingiram o equilíbrio, forneceu bases empíricas para a discussão da evolução das feições erosivas lineares em relação ao limite crítico topográfico e também para o entendimento dos estados estável e instável dos voçorocamentos. Considerando o limite crítico como ponto máximo que as feições erosivas têm a possibilidade de alcançar, verificouse que as feições erosivas estabilizadas estão mais próximas das condições máximas de desenvolvimento, e por isso, não se observam mais processos de recuo das suas cabeceiras. Por outro lado, as feições erosivas ativas estão um pouco mais distantes do limite crítico e, por esse motivo, ainda têm área de contribuição suficiente para promover o recuo de suas cabeceiras. Foi identificado nesta pesquisa que quase todas as feições erosivas atualmente estão estabilizadas ou próximas do equilíbrio, de modo que mesmo as feições mais ativas não apresentam muitos indicadores da ocorrência de processos presentes.

Foi construído um modelo teórico de previsão da estabilidade e instabilidade das feições erosivas baseado na relação SA em diferentes perfis de encosta. No caso das encostas convexas em perfil, a diminuição da área de contribuição é acompanhada pela diminuição da declividade, fazendo com que a condição de equilíbrio seja atingida mais rapidamente do que encostas com perfil retilíneo. Devido ao baixo coeficiente $b$ do limite crítico topográfico, se a evolução remontante ocorrer em encostas retilíneas são necessárias áreas de contribuição extremamente pequenas para permitir a estabilização das voçorocas, o que faria com que as cabeceiras se localizassem praticamente junto ao divisor de águas. Já nos perfis de encosta 
côncavos, constatou-se que muito dificilmente uma voçoroca irá se estabilizar (ou deixar de evoluir remontantemente), pois a relação SA tende a estar sempre acima do limite crítico topográfico. Entre as únicas possibilidades de uma voçoroca deixar de avançar em encostas côncavas em perfil está o substrato, ou seja, nos casos em que a declividade aumenta tanto a montante que permite exclusivamente o desenvolvimento de solos rasos ou até mesmo provoca o afloramento do substrato rochoso, impedindo a continuação dos processos erosivos. 


\section{REFERÊNCIAS BIBLIOGRÁFICAS}

AHNERT, F. (1996) Introduction to Geomorphology. London: Arnold, 352p.

ALMEIDA FILHO, G. S. (2000) Diagnóstico de processos erosivos lineares associados a eventos pluviosos no município de Bauru, SP. Campinas (SP): UNICAMP. Dissertação de Mestrado - Universidade Estadual de Campinas, 224p.

ARAUJO, T. P. (2011) Estudo do desencadeamento das erosões lineares concentradas em uma área do município de São Pedro / SP. São Carlos (SP): USP. Dissertação de Mestrado - Universidade de São Paulo, 181p.

AUGUSTIN, C. H. R. R.; ARANHA, P. R. A. (2006) Piping em área de voçorocamento, Noroeste de Minas Gerais. Revista Brasileira de Geomorfologia, ano 7, n. 1, p. 9-18.

BRYAN, R. B. (2000) Soil erodibility and processes of water erosion on hillslope. Geomorphology, v. 32, p. 385-415.

BULL, L. J.; KIRKBY, M. J. (1997) Gully processes and modeling. Progress in Physical Geography, v. 21, n. 3, p. 354-374.

CAMPBELL, I. A.; HONSAKER, J. L. (1982) Variability in badlands erosion; problems of scale and threshold identification. In: THORN, C. E. (Ed.) Space and Time in Geomorphology. London: George Allen \& Unwin, p. 59-79.

CANIL, K. (2000) Processos erosivos e planejamento urbano: carta de risco de erosão das áreas urbana e periurbana do município de Franca, SP. São Paulo (SP): USP. Dissertação de Mestrado - Universidade de São Paulo, 96p.

CASALÍ, J.; LÓPEZ, J. J.; GIRÁLDEZ, J. V. (1999) Ephemeral gully erosion in southern Navarra (Spain). Catena, v. 36, p. 65-84.

CASTRO, S. S. (2005) Erosão hídrica na Alta Bacia do Rio Araguaia: distribuição, condicionantes, origem e dinâmica atual. Revista do Departamento de Geografia, São Paulo (SP), n. 17, p. 38-60.

CASTRO, S. S.; QUEIROZ NETO, J. P. (2009) Soil erosion in Brazil from coffee to the present day soy bean production. In: LATRUBESSE, E. M. (Org.) Natural hazards and human-exacerbated disasters in Latin America. Amsterdam: Elsevier, 13 ed., p. 195-221.

CATI (2003) Situação socioeconômica inicial da microbacia piloto córrego Água da Faca - Piratininga/SP. Bauru (SP): Coordenadoria de Assistência Técnica Integral da Secretaria de Agricultura e Abastecimento do Estado de São Paulo - Regional Bauru (CATI), 96p.

CATI (2004) Flora e fauna - Relatório final: microbacia ribeirão Água da Faca no município de Piratininga (EDR Bauru). Bauru (SP): Coordenadoria de Assistência Técnica Integral da Secretaria de Agricultura e Abastecimento do Estado de São Paulo - Regional Bauru (CATI), 89p.

CHORLEY, R. J. (1971) A Geomorfologia e a Teoria dos Sistemas Gerais. Notícias Geomorfológicas, Campinas (SP), n. 11, p. 03-22. 
CHRISTOFOlEtTI, A. (1979) Análise de Sistemas em Geografia. São Paulo (SP): Ed. Hucitec, 105p.

COELHO NETTO, A. L. (2003) Evolução de cabeceiras de drenagem no médio vale do Rio Paraíba do Sul (SP/RJ): a formação e o crescimento da rede de canais sob controle estrutural. Revista Brasileira de Geomorfologia, ano 4, n. 2, p. 69-100.

CROZIER, M. J. (1999) The frequency and magnitude of geomorphic processes and landform behavior. Zeitschirift für Geomorphologie N. F., Supplement Band n. 115, p. 35-50.

CRUZ, O. (1985) A escala temporal-espacial nos estudos dos processos geomorfológicos erosivos atuais. Uma questão de método. Geomorfologia, São Paulo (SP): Instituto de Geografia da Universidade de São Paulo, 6p.

DAEE/IPT. (1990) Controle de Erosão. São Paulo (SP): Departamento de Águas e Energia Elétrica (Secretaria de Energia e Saneamento do Estado de São Paulo) / Instituto de Pesquisas Tecnológicas (IPT), 2. ed., 92p.

DIETRICH, W. E.; WILSON, C. J.; MONTGOMERY, D. R.; MCKEAN, J.; BAUER, R. (1992) Erosion thresholds and land surface morphology. Geology, v. 20, p. 675-679.

DIETRICH, W. E.; WILSON, C. J.; MONTGOMERY, D. R.; MCKEAN, J. (1993) Analysis of erosion thresholds, channel networks, and landscape morphology using a Digital Terrain Model. The Journal of Geology, v. 101, n. 2, p. 259-278.

DRUMOND, F. N.; BACELLAR, L. A. P. (2006) Caracterização hidro-sedimentológica e dos processos evolutivos de voçoroca em área de rochas gnáissicas do alto Rio das Velhas (MG). Revista Brasileira de Geomorfologia, ano 7, n. 2, p. 87-96.

FAULKNER, H.; ALEXANDER, R.; TEEUW, R.; ZUKOWSKYJ, , P. (2004) Variations in soil dispersivity across a gully head displaying shallow sub-surface pipes, and the role of shallow pipes in rill initiation. Earth Surface Processes and Landforms, v. 29, p. 11431160 .

FURLANI, G. M. (1980) Estudo geomorfológico das boçorocas de Casa Branca. São Paulo (SP): USP. Dissertação de Mestrado - Universidade de São Paulo, 379p.

GUERRA, A. J. T. (1994) Processos erosivos nas encostas. In: GUERRA, A. J. T.; CUNHA, S. B. (Orgs.). Geomorfologia: uma atualização de bases e conceitos. Rio de Janeiro (RJ): Bertrand Brasil, p. 149-209.

HORTON, R. E. (1945) Erosional development of streams and their drainage basins; hydrophysical approach to quantitative morphology. Geological Society of America Bulletin, v. 56, p. 275-370.

HOWARD, A. D. (1965) Geomorphological systems - equilibrium and dynamics. American Journal of Science, v. 263, p. 302-312.

HUGGETT, R. J. (2003) Fundamentals of Geomorphology. London: Routledge, 386p. 
IPT (1981) Mapa Geológico do Estado de São Paulo, escala 1:500.000. São Paulo (SP): Instituto de Pesquisas Tecnológicas do Estado de São Paulo.

IPT (1994) Carta Geotécnica do Estado de São Paulo, escala 1:500.000. São Paulo (SP): Instituto de Pesquisas Tecnológicas do Estado de São Paulo.

JONES, J. A. A.; RICHARDSON, J. M.; JACOB, H. J. (1997) Factors controlling the distribution of piping in Britain: a reconnaissance. Geomorphology, v. 20, p. 289-306.

JUNGERIUS, P. D.; VAN DEN BRINK, J. W. (1991) The geomorphology of a gully wall: an example of the application of geomorphological mapping to process research. In: BORK, H. -R. et al. (Eds.) Erosion, transport and deposition processes: theories and models. Catena Supplement 19, p. 57-69.

KIRKBY, M. J.; BRACKEN, L. J. (2009) Gully processes and gully dynamics. Earth Surface Processes and Landforms, v. 34, p. 1841-1851.

LOHMANN, M.; SANTOS, L. J. C. (2005) A morfopedologia aplicada à compreensão dos processos erosivos na bacia hidrográfica do Arroio Guassupi, São Pedro do Sul - RS. Revista Brasileira de Geomorfologia, ano 6, n. 2, p. 91-102.

MARTÍNEZ-CASASNOVAS, J. A. (2003) A spatial information technology approach for the mapping and quantification of gully erosion. Catena, v. 50, p. 293-308.

MONTGOMERY, D. R.; DIETRICH, W. E. (1988) Where do channels begin? Nature, v. 336, n. 6196, p. 232-234.

MONTGOMERY, D. R.; DIETRICH, W. E. (1989) Source areas, drainage density, and Channel Initiation. Water Resources Research, v. 25, n. 8, p. 1907-1918.

MONTGOMERY, D. R.; DIETRICH, W. E. (1994) Landscape dissection and drainage areaslope thresholds. In: KIRKBY, M. J. (Ed.) Process Models and Theoretical Geomorphology. New York: John Wiley \& Sons Ltd., p. 221-246.

MONGOMERY, D. R.; FOUFOULA-GEORGIOU, E. (1993) Channel network source representation using Digital Elevation Models. Water Resources Research, v. 29, n. 12, p. 3925-3934.

MORGAN, R. P. C.; MNGOMEZULU, D. (2003) Threshold conditions for initiation of valley-side gullies in the Middle Veld of Swaziland. Catena, v. 50, p. 401-414.

NAKASHIMA, M. S. R. (1999) Análise dos processos erosivos e da fragilidade ambiental na bacia do Rio Keller - PR. São Paulo (SP): USP, 2v. Tese de Doutorado - Universidade de São Paulo, 189p.

OLIVEIRA, A. M. S.; QUEIROZ NETO, J. P. (1993) Erosão acelerada no Planalto Ocidental Paulista: desequilíbrio, descontinuidade e epiciclo. In: V SIMPÓSIO BRASILEIRO DE GEOGRAFIA FÍSICA APLICADA, São Paulo (SP). Anais do V SIMPÓSIO BRASILEIRO DE GEOGRAFIA FÍSICA APLICADA. São Paulo (SP): Departamento de Geografia - USP, p. 461-463. 
OOSTWOUD WIJDENES, D. J.; BRYAN, R. B. (1991) Gully development on the Njemps Flats, Baringo, Kenya. In: BORK, H. -R.; DE PLOEY, J.; SCHIK, A. P. (Eds.) Erosion, transport and deposition processes: theories and models. Catena Supplement, v. 19, p. 7190 .

OOSTWOUD WIJDENES, D. J.; POESEN, J.; VANDEKERCKHOVE, L.; NACHTERGAELE, J.; DE BAERDEMAEKER, J. (1999) Gully-head morphology and implications for gully development on abandoned fields in a semi-arid environment, Sierra de Gata, Southeast Spain. Earth Surface Processes and Landforms, v. 24, p. 585-603.

PAISANI, J. C.; OLIVEIRA, M. A. T. (2001) Desenvolvimento de incisão erosiva (voçoroca) descontínua e desconectada da rede hidrográfica em área de cabeceira de drenagem: o caso da Colônia Quero-Quero (Palmeira - PR). Revista Brasileira de Geociências, v. 31, p. 51-58.

PATTON, P. C.; S. A. SCHUMM (1975) Gully erosion, Northwestern Colorado: a threshold phenomenon. Geology, v. 3, n. 2, p. 88-90.

POESEN, J.; NACHTERGAELE, J.; VERSTRAETEN, G.; VALENTIN, C. (2003) Gully erosion and environmental change: importance and research needs. Catena, v. 50, p. 91-133.

PROSSER, I. P.; ABERNETHY, B. (1996) Predicting the topographic limits to a gully network using a digital terrain model and process thresholds. Water Resources Research, v. 32, n. 7, p. 2289-2298.

QUEIROZ NETO, J. P. (2001) Erosão dos solos tropicais e seu controle: o exemplo do Estado de São Paulo. In: VII SIMPÓSIO NACIONAL DE CONTROLE DE EROSÃO, Goiânia (GO). Anais do VII SIMPÓSIO NACIONAL DE CONTROLE DE EROSÃO. Goiânia (GO): Associação Brasileira de Geologia de Engenharia - ABGE, 11p.

RAMOS, V. M.; GUIMARÃES, R. F.; REDIVO, A. L.; CARVALHO JR., O. A.; FERNANDES, N. F.; GOMES, R. A. T. (2003) Avaliação de metodologias de determinação do cálculo de áreas de contribuição. Revista Brasileira de Geomorfologia, ano 4, n. 2, p. 4149.

RICCOMINI, C. (1997) Arcabouço Estrutural e Aspectos do Tectonismo gerador e deformador da Bacia Bauru no Estado de São Paulo. Revista Brasileira de Geociências, v. 27 , p. $153-162$.

RITTER, D. F.; KOCHEL, R. C.; MILleR, J. R. (1995) Process Geomorphology. Wm. C. Brown Publishers, 3. ed., 546p.

ROSS, J. L. S.; MOROZ, I. C. (1997) Mapa Geomorfológico do Estado de São Paulo, escala 1:500.000. São Paulo (SP): Universidade de São Paulo (USP).

RUHE, R. V. (1975) Geomorphology. U.S.: Houghton Mifflin Company, 246p.

SAlGADO, C. M.; SILVA, T. P.; PEIXOTO, M. N. O.; MOURA, J. R. S. (2008) Análise espaço-temporal da erosão linear no médio-baixo vale do Ribeirão do Secretário (Paty do Alferes/RJ). Revista Brasileira de Geomorfologia, ano 9, n. 1, p. 75-85. 
SALOMÃO, F. X. T. (1994) Processos erosivos em Bauru (SP): regionalização cartográfica aplicada ao controle preventivo urbano e rural. São Paulo (SP): USP. Tese de Doutorado - Universidade de São Paulo, 200p.

SANTOS, L. J. C. (1995) Estudo morfológico da topossequência da Pousada da Esperança, em Bauru, SP: subsídio para a compreensão da gênese, evolução e comportamento atual dos solos. São Paulo (SP): USP. Dissertação de Mestrado Universidade de São Paulo, 124p.

SANTOS, L. J. C.; CASTRO, S. S.; GRIMALDI, M. (2001) O comportamento físico-hídrico de coberturas com Latossolos e Argissolos e suas relações com o desenvolvimento dos processos erosivos lineares na região de Bauru (SP). In: VII SIMPÓSIO NACIONAL DE CONTROLE DE EROSÃO, Goiânia (GO). ANAIS DO VII SIMPÓSIO NACIONAL DE CONTROLE DE EROSÃO. Goiânia (GO): Associação Brasileira de Geologia de Engenharia - ABGE, 5p.

SANTOS, L. J. C.; CASTRO, S. S. (2006) Lamelas (Bandas Onduladas) em Argissolo Vermelho-Amarelo como indicadores da Evolução do Relevo: o caso das Colinas Médias do Platô de Bauru (SP). Revista Brasileira de Geomorfologia, União da Geomorfologia Brasileira, ano 7, n. 1, p. 43-64.

SCHUMM, S. A.; LICHTY, R. W. (1965) Time, space and causality in Geomorphology. American Journal of Science, v. 263, p. 110-119.

SCHUMM, S. A. (1973) Geomorphic thresholds and complex response of drainage systems. In: MORISAWA, M. (Ed.) Fluvial Geomorphology. New York: State University of New York, p. 299-310.

SCHUMM, S. A. (1979) Geomorphic thresholds: the concept and its applications. Transactions of the Institute of British Geographers, v. 4, n. 4, p. 485-515.

SIDORCHUK, A. (1999) Dynamic and static models of gully erosion. Catena, v. 37, p. 401414.

SIDORCHUK, A. (2006) Stages in gully evolution and self-organized criticality. Earth Surface Processes and Landforms, v. 31, p. 1329-1344.

SOBREIRA, F. G.; BACELLAR, L. A. P. (1999) Erosões aceleradas em Cachoeira do Campo, Ouro Preto, MG: cadastro e avaliação do estágio evolutivo. In: IX CONGRESSO BRASILEIRO DE GEOLOGIA DE ENGENHARIA, São Pedro (SP). CD-ROM do IX CONGRESSO BRASILEIRO DE GEOLOGIA DE ENGENHARIA. São Pedro (SP): Associação Brasileira de Geologia de Engenharia - ABGE, 14p.

STABILE, R. A. (2009) Análise do papel exercido pela topografia na distribuição das feições erosivas lineares na bacia Água da Faca, Piratininga (SP). São Paulo (SP): USP. Trabalho de Graduação Individual - Universidade de São Paulo, 81p.

STABILE, R. A.; VIEIRA, B. C. (2009a) O papel do ângulo da encosta e da forma das vertentes na distribuição das feições erosivas da bacia Água da Faca, Piratininga (SP). In: XIII SIMPÓSIO BRASILEIRO DE GEOGRAFIA FÍSICA APLICADA, Viçosa (MG). CD-ROM DO XIII SIMPÓSIO BRASILEIRO DE GEOGRAFIA FÍSICA APLICADA. Viçosa (MG): Universidade Federal de Viçosa - UFV, 11p. 
STABILE, R. A.; VIEIRA, B. C. (2009b) The role of the topography in the distribution of gully erosion in the Southeastern Brazil. In: VII INTERNATIONAL CONFERENCE ON GEOMORPHOLOGY, Melbourne (Austrália). CD-ROM DA VII INTERNATIONAL CONFERENCE ON GEOMORPHOLOGY. Melbourne (Austrália): International Association of Geomorphologists - IAG, 1p.

TANAKA, Y.; AGATA, Y. (2002) Effects of runoff characteristics on the frequency of slope failures in Soya Hills, northern Japan. In: ALLISON, R. J. (Ed.) Applied Geomorphology: theory and practice. New York: John Wiley \& Sons Ltd., p. 101-112.

VANDAELE, K.; POESEN, J.; GOVERS; G.; VAN WESEMAEL, B. (1996) Geomorphic threshold conditions for ephemeral gully incision. Geomorphology, v. 16, p. 161-173.

VANDEKERCKHOVE, L.; POESEN, J.; OOSTWOUD WIJDENES, D. J.; GYSSELS, G.; BEUSELINCK, L.; DE LUNA, E. (2000) Characteristics and controlling factors of bank gullies in two semi-arid Mediterranean environments. Geomorphology, v. 33, p. 37-58.

VANWALLEGUEM, T.; POESEN, J.; NACHTERGAELE, G.; VERSTRAETEN, G. (2005) Characteristics, controlling factors and importance of deep gullies under cropland on loessderived soils. Geomorphology, v. 69, p. 76-91.

VERACHTERT, E.; VAN DEN EECKHAUT, M.; POESEN, J.; DECKERS, J. (2010) Factors controlling the spatial distribution of soil piping erosion on loess-derived soils: a case study from central Belgium. Geomorphology, v. 118, p. 339-348.

VIEIRA, N. M. (1978) Estudo geomorfológico das boçorocas de Franca - SP. Franca (SP): UNESP. Tese de Doutorado - Universidade Estadual Paulista, 226p.

VIEIRA, A. C. F. (2002) Controles morfológicos para a iniciação de canais em encostas naturais por fluxos superficiais: evidências de campo e modelagem. Rio de Janeiro (RJ): UFRJ. Dissertação de Mestrado - Universidade Federal do Rio de Janeiro, 94p.

WOLMAN, M. G.; MILLER, J. P. (1960) Magnitude and frequency of forces in geomorphic processes. Journal of Geology, v. 68, p. 54-74.

WU, Y; CHENG, H. (2005) Monitoring of gully erosion on the Loess Plateau of China using a global positioning system. Catena, v. 63, p. 154-166. 
ANEXOS

\section{ANEXO I - Ficha de campo para caracterização das feições erosivas}

\begin{tabular}{|c|c|c|c|c|}
\hline & & AVALIAÇ, & AO EROSIVA LINE. & \\
\hline 1. Identificaçã & oel & ocalização & & \\
\hline NFeição: & & & NoArea: & \\
\hline Coordenadas & & Latit: & Coordenadas do & Latit.: \\
\hline cabeceira: & - & Long.: & ponto de início: & Long.: \\
\hline 2. Característi & case & indicadores da feição & & \\
\hline Conexão com & are & de de drenagem: & & \\
\hline Forma em pla & ntac c & la feição/da cabeceira: & & \\
\hline Cabeceira ep & $\overline{a r e d}$ & es abruptas ou suaves (em & & \\
\hline Fundo plano $/ 1$ & fund & o irregular: & & \\
\hline Sinais de oigin & & & & \\
\hline Sinais de flutio & & & & \\
\hline Presença de $R$ & lung & (epool: & & \\
\hline Rachaduras o & uevi & dências de solapamento na & & \\
\hline Presença dev & eget & ação nas paredes e fundo: & & \\
\hline Afloramento d & oler & ç̧ol freático: & & \\
\hline Afloramento d & eare & enito no fundo ou cabeceira & & \\
\hline Ocorrência de & des & continuidades: & & \\
\hline Trilhas de piso & teio & de gado ou terracetes a mo & & \\
\hline Elementos cor & רcen & tradores de água a montan & aminhos, etc.): & \\
\hline Medidas de es & tabi & lização antrópica (barrame & de vegetação, etc.): & \\
\hline 3. Característi & cas c & Ja área de contribuição & & \\
\hline Uso do solo: & & & & \\
\hline Medidas de pr & $\overline{\text { oteç }}$ & ăo do solo: & & \\
\hline 4. Medições de & ear & npo & & \\
\hline Profundidade & dac & abeceira (metros): & & \\
\hline & & nedida ( 0,0 a 1,5 metros): & & \\
\hline Declividade & & nedida ( 1,5 a 3,0 metros): & & \\
\hline cabeceira & & nedida ( 3,0 a 4,5 metros): & & \\
\hline & & nedida ( 4,5 a 6,0 metros): & & \\
\hline No Fotos: & & & & \\
\hline
\end{tabular}

